\title{
State TANF Time Limit and Work Sanction Stringencies and Long-Term Trajectories of Welfare Use, Labor Supply, and Income
}

\author{
Julia Shu-Huah Wang ${ }^{1}$
}

Accepted: 16 September 2020/Published online: 14 October 2020

(C) Springer Science+Business Media, LLC, part of Springer Nature 2020

\begin{abstract}
While the 1996 welfare reform increased employment and reduced the participation of the Temporary Assistance for Needy Families (TANF) program immediately after its inception, little is known about the extent to which the reform and stringencies of time limit and work sanction policy features have impacted individuals in the long term. This study used the Survey of Income and Program Participation 1996, 2001, and 2004 panels (1996-2007) and a difference-in-difference-indifference design to follow low-skilled single mothers' trajectories of welfare use, labor supply, and income for 10 years after the welfare reform and compare how these trajectories differ by stringencies of state work sanction and time limit policies. The findings indicate that welfare reform had sustained impacts on reducing welfare use (TANF and the Supplemental Nutrition Assistance Program [SNAP] program) and increasing employment. Stringent work sanction and time limit policies were associated with lower TANF participation rates in the long term, but only short time limit policies were associated with reduced SNAP participation. Neither stringent policy feature increased employment nor income. The differential effects by race were also examined and discussed.
\end{abstract}

Keywords TANF - Sanction policy · Time limits - Welfare use · Labor supply · Earnings · Long-term trajectories · Single mothers

\section{Introduction}

The 1996 Personal Responsibility and Work Opportunity Reconciliation Act (PRWORA) in the United States ended the longstanding entitlement cash assistance program, Aid to Families with Dependent Children (AFDC), and fundamentally transformed the social assistance system in the US. The welfare reform established a work-focused and time-limited program, Temporary Assistance for Needy Families (TANF). The main goals of TANF are to end welfare dependence, promote work and self-reliance, and reduce out-of-wedlock childbearing among the poor. To achieve these goals, states adopted varying TANF policy requirements, of which the most controversial features were work requirements, sanctions, and time limits (Ziliak 2016).

\section{Julia Shu-Huah Wang}

jshwang@hku.hk

1 The University of Hong Kong, Pokfulam Road, Hong Kong, China
The TANF law stipulated that adults must participate in work activities, and noncompliance with work requirements will result in sanctions on benefits in most states. TANF also imposed a maximum lifetime limit of 60 months on federal welfare benefits (Grogger and Karoly 2005; Ziliak 2016). Each state was given the option to set its own requirements with varying stringencies. These requirements were intended to give families a sense of urgency regarding the temporary nature of welfare assistance so that they would promptly move from welfare to work (Pavetti et al. 2003; Farrell et al. 2008). Studies find that stringent measures reduced welfare use and increased employment levels in the immediate aftermath of the welfare reform (Blank 2002; Grogger and Karoly 2005; Farrell et al. 2008; Ziliak 2016). However, whether or not stringent requirements sustain these behavioral effects beyond the initial three to 5 years post-welfare reform in the long term remains unknown. This study first followed low-skilled single mothers' trajectories of welfare use, labor supply, and income for 10 years after the welfare reform and then examined the critical question of the 
conditions under which differences in state TANF policy stringencies were associated with the above long-term outcomes among disadvantaged single mothers. A broader social welfare question that this study explores is whether or not harsher behavioral requirements or conditionalities attached to welfare or services could lead to or sustain longer-term intended behavioral outcomes.

In this study, the outcomes under examination are families' economic self-sufficiency levels, captured by whether or not families living in states with stringent TANF requirements use welfare programs less, participate in work activities more, and earn more income (Freeman 1996; Morgen 2001). Understanding the long-term impacts of state TANF policy stringencies on welfare use, labor supply, and income has implications for families in need of government assistance and for policymakers crafting the next phase of cash assistance systems. From the viewpoint of needy families, state TANF policies have affected millions of people in poverty in terms of their experience of obtaining governmental support each year. The number of families receiving TANF assistance was 3.7 million in 1997, 1.7 million in 2007, and 1.1 million in 2017 (Administration for Children and Families [ACF] 2018). However, more families were affected by TANF policies than the aforementioned numbers, as some families were eligible yet deterred from applying for it due to the harsh requirements and some could not receive TANF because they reached the time limits or were sanctioned. ${ }^{1}$ While welfare reform reduces welfare caseloads and in turn reduces government expenditure on TANF cash assistance in the name of promoting work and self-reliance, such costcutting benefits come at the expense of the well-being of some population groups who have been traditionally discriminated against in or socially excluded from the labor market and life opportunities (e.g., education and training). For instance, studies have shown that racial minorities are more likely to be sanctioned or have reached time limits than Whites, and Blacks are more prone to experiencing suboptimal outcomes after leaving welfare than Whites (Keiser et al. 2004; Schram 2005; Schram et al. 2009). If stringent requirements are not effective at achieving the main policy goal-encouraging families to achieve economic self-sufficiency-in the long term, the necessity of adopting harsh measures may warrant reevaluation. Also, examining how welfare stringencies differently affect longterm outcomes of racial minority families can further shed light on the discussion on the extent to which the welfare system is a race-biased regime (Schram 2005). From the viewpoint of policy reform, empirical evaluations offer

\footnotetext{
${ }^{1}$ In $2009,6.2 \%$ of welfare case closures were due to families being sanctioned for noncompliance with work requirements, and $2.3 \%$ were due to time limits being reached (ACF 2009).
}

much-needed evidence for reevaluating and redesigning the cash assistance system. For example, as states faced budget constraints, particularly during the Great Recession, many states made welfare requirements more stringent (e.g., shortening time limits or applying stricter sanction policies) and made welfare less desirable in order to cut costs (Danziger et al. 2016). Facing an even greater economic contraction due to the COVID-19 pandemic, states encounter challenges to adjust TANF's work and other requirements to meet the emergent needs. Such policy change decisions would have benefited from more knowledge of the long-term impacts of stringent policy requirements to assess the cost-effectiveness and necessity of employing stringent approaches.

More than 20 years after the welfare reform, more years of data have become available, offering opportunities to assess the long-term impacts of TANF policies. Despite the flurry of literature on welfare reform, a recent review of TANF research by Ziliak (2016) concludes that it is still premature to draw firm conclusions about the impacts of TANF, particularly its policy effects over time. Our knowledge is generally limited to the evidence from the first 5 years after the introduction of TANF. However, it is alarming that the amount of research on welfare reform has gradually decreased in recent years (Ziliak 2016). This study responds to this research gap and extends our knowledge about the long-term impacts of state TANF policy stringencies on employment, income, and welfare use. Furthermore, I delineate the differential long-term effects by race.

Against this backdrop, this study uses a nationally representative short panel dataset- the Survey of Income and Program Participation (SIPP) - to assess the long-term impacts of TANF work sanction and time limit policy stringencies. I address the following key research question: Did stringent TANF requirements successfully prompt individuals to work more, increase their earnings, and lower welfare use in the long term? In particular, I adopt a difference-in-difference-in-difference (DDD) design to compare welfare use, labor supply, and income trajectories before and after the welfare reform among low-skilled single mothers (with a high school degree or a lower level of education) and their married counterparts living in states with strict and standard work sanction and time limit policies. I account for preexisting differences among states using state fixed effects and multilevel models. Findings from this study could inform ongoing initiatives to redesign state TANF policies ${ }^{2}$ and may help shed light on debates worldwide regarding the effectiveness of workfare policies.

\footnotetext{
${ }^{2}$ Examples of these initiatives include a bi-partisan TANF reform bill proposed by U.S. Sens. Shelley Moore Capito (R-WV) and Kelly Ayotte (R-NH) (see https://www.nationalskillscoalition.org/news/ latest/capito-ayotte-introduce-bipartisan-bill-to-reform-improve-pov erty-programs) and various state-level reform initiatives (see https://
} 


\section{Temporary Assistance to Needy Families (TANF)}

Under the longstanding cash assistance program, AFDC, welfare caseloads increased substantially by one million (from 3.7 to 4.7 million) within just 6 years, from 1986 to early 1992 (ACF 2018). Concerns that the AFDC created disincentives for poor single mothers to work gave rise to the PRWORA in 1996. The PRWORA established a timelimited and work-focused program, TANF. Under this program, state social assistance provision is contingent upon work or work-related activities, such as job training, job searching, and job readiness assistance. Under the typical guidelines, adult caretakers who are not exempt from work requirements need to be working at least $30 \mathrm{~h}$ per week no later than 24 months after the receipt of benefits (Ziliak 2016). In addition to this guideline, individuals are subject to a federal 60-month lifetime limit on welfare.

Under TANF, states set their own welfare rules in areas such as eligibility, benefits, behavioral requirements, time limits, and welfare sanctions. This devolution has created a great variation in TANF program policies across the country. For example, although the federal government funds up to 60 months of TANF assistance in a recipient's lifetime, some states forego the federal funds and set time limits that are shorter than 60 months (e.g., Connecticut has a 24-month time limit) (Farrell et al. 2008). In terms of work sanctions, some states terminate the full benefit amount or close the case upon the initial incidence of noncompliance with work requirements (e.g., Florida and Idaho), while others impose partial sanctions on benefits (e.g., Alabama and Illinois) or no sanctions at all (e.g., Massachusetts). ${ }^{3}$ The maximum monthly benefit for a three-person family in 2014 could be as low as $\$ 170$ (Mississippi) or as high as $\$ 789$ (New York) (Huber et al. 2015). Taking different aspects of TANF requirements into account, states' decisions regarding each of the TANF policy rules have formed a myriad of state social assistance policy packages.

To evaluate the impacts of policy stringencies, the policy characteristics that affect the lives of families in need, one major challenge is defining stringencies. Despite numerous attempts in past literature to construct measures summarizing state TANF policy rules in a parsimonious

Footnote 2 continued

peerta.acf.hhs.gov/content/state-tanf-redesignhuman-services-modernization-efforts).

3 The number of states with lenient policies (e.g., no time limit or no sanctions) was too small for meaningful analyses. Therefore, this study focuses only on the long-term impacts of stringent features of state TANF policies. Please see Appendix Tables 19 and 20 for evolution of state requirements across years. manner, there has not been a consensus on the measure of stringencies; hence, no scales or indices have been repeatedly used or adopted in evaluations of TANF policy impacts (Ellwood 2000; Meyer and Rosenbaum 2001; Grogger and Karoly 2005; De Jong et al. 2006; Ziliak 2016). Many TANF studies on policy features have focused on time limits and sanction policies on noncompliance with work requirements (Lindhorst and Mancoske 2006; Danielson and Klerman 2008; Ziliak 2016). Following these studies, this paper focuses on these two prominent policy features to measure state TANF policy stringencies.

\section{Literature Review}

Extant research has documented the way in which the AFDC waiver policies, ${ }^{4}$ the TANF policy bundle, and stringent state TANF requirements were successful in reducing welfare caseloads, promoting employment, and modestly increasing earnings among low-income families prior to the welfare reform or in the years immediately following the reform (Grogger and Karoly 2005; Ziliak 2016). In the long term, the employment and earnings effects of waiver policies taper off (Grogger and Karoly 2005), and such effects of stringent requirements remain largely unknown.

\section{Welfare Use}

The welfare reform has led to a reduction in welfare participation (Huang et al. 2000; Grogger and Karoly 2005; Ziliak 2016). Welfare caseloads fell from 5 million families in 1993, 3.7 million in 1997, and 1.7 million in 2007 to 1.1 million in 2017 (Loprest 2012; ACF 2018). Nearly half of the decline in caseloads was driven by a reduction in welfare entry rather than welfare exit (Grogger et al. 2003). The take-up rates of cash benefits decreased from $79 \%$ in the last year of AFDC to 36\% in 2007 (Loprest 2012). Research has also shown that this decline was not entirely due to the effects of welfare reform. To a larger extent, the decline was attributed to the booming economy of the late 1990s and the expansion of the earned income tax credit

\footnotetext{
$\overline{4}$ Title IV-A of the Social Security Act established the AFDC program. Section 1115 of the Act authorizes the Secretary of Health and Human Services (HHS) to waive certain requirements for a state to carry out an experimental or pilot project to promote the purposes of the AFDC programs. Between January 1993 and August 1996, the HHS approved welfare waivers in 43 states. These waivers introduced time limits, work requirements, and sanctions and expanded earnings disregards and asset limits (Department of Health and Human Services, 2016; Ziliak 2016).
} 
(EITC) (Meyer and Rosenbaum 2001; Blank 2002; Klerman and Haider 2004; Ziliak 2009).

Prior research on the impacts of specific state TANF policy requirements has revealed that time limits accounted for $6 \%$ to $25 \%$ of the decline in welfare participation, depending on the study period and the datasets used (Council of Economic Advisers 1999; Moffitt 1999; Grogger 2004; Swann 2005; Mazzolari 2007). Both behavioral effects, such as reducing welfare use prior to exhausting benefits, and mechanical effects, meaning not receiving welfare due to reaching time limits, have been observed in prior studies (Grogger and Karoly 2005). Compared with lenient ones, stringent sanction policies on noncompliance with work requirements decrease welfare caseloads; more stringent sanctions have stronger effects (Council of Economic Advisers 1999; Rector and Youssef 1999; Grogger and Karoly 2005).

\section{Employment and Earnings}

Studies have revealed that welfare reform and work requirements in waiver programs had positive effects on the extensive and intensive margins of employment (Blank 2002; Grogger and Karoly 2005). Low-skilled mothers (e.g., those with a high school degree or less) responded to the waiver policies by increasing annual hours worked by 41 to $68 \mathrm{~h}$ and increasing employment rates by an average of 5.6\% points (Moffitt 1999; Schoeni and Blank 2000; Grogger and Karoly 2005). However, the employment effect faded during the 3 years after the policy change (Grogger and Karoly 2005; Dyke et al. 2006; Hotz et al. 2006).

With respect to earnings, state waiver policies increased the annual earnings among mothers during the prePRWORA period (Moffitt 1999; Schoeni and Blank 2000; Blank 2002; Grogger and Karoly 2005). Among 13 waiver programs evaluated by Grogger and Karoly (2005), nine produced positive and significant earnings effects, with an average of $\$ 700$ earnings gain during the first 2 years. In the long term, the earnings impact modestly faded from $\$ 378$ per year in the short term to $\$ 324$ per year in years 4 and 5 (Grogger and Karoly 2005). In regard to the earnings effects of the TANF policy (post-PRWORA), studies have shown a modest or no increase in earnings post-reform (Grogger 2003; Grogger and Karoly 2005). None of the estimates of TANF's earnings effects have suggested that the reform increased earnings substantially, definitely not by amounts that would lift many poor families out of poverty (Grogger and Karoly 2005).

Although prior research attributes $60 \%$ to $73 \%$ of employment growth post-welfare reform to the EITC and/ or the macroeconomic environment rather than to the reform itself (Meyer and Rosenbaum 2001; Fang and
Keane 2004), state welfare policies also play a role in promoting employment. For example, time limits have been shown to boost low-educated mothers' employment rate by as much as 7\% points between 1995 and 1999 and account for 10 percent of total employment growth from 1993 to 2002 (or 15 percent of employment growth between 1984 and 1996) (Kaushal and Kaestner 2001; Grogger 2003; Fang and Keane 2004). Nonetheless, other studies show that time limits have little to no impact on employment or earnings (Grogger 2003; Lim et al. 2009). With respect to sanctions, few studies have identified sanctions' impacts on labor supply and earnings, and among the few that have, the impacts of sanction policies on employment were found to be null or positive (Pavetti et al. 2003; Lee et al. 2004). In particular, some evidence has revealed that sanctions encouraged individuals to engage in informal work and job preparation activities (Lee et al. 2004; Wu et al. 2014).

Overall, prior research has two main limitations. First, evaluations of TANF requirement stringencies based on state-wide experiments or observational designs generally examine only policy impacts around the period of welfare reform and use data up to 2000, when few recipients had exhausted their time limits and the economy was strong. Evaluations of that time period also could not capture the longer-term influences of larger-scale changes in norms and expectations regarding welfare recipiency and work after the nationwide implementation of the PRWORA (Duncan and Chase-Lansdale 2001; Ziliak 2016). Another limitation of earlier research is that the long-term impacts of various state requirements are largely unexplored. Requirements such as time limits or sanctions take a toll on families in need. In 2009, 6.2\% of welfare case closures were due to families being sanctioned for noncompliance with work requirements, and $2.3 \%$ were due to time limits being reached (ACF 2009). ${ }^{5}$ Case closures due to sanctions and time limits are associated with material hardships experienced by families (Kalil et al. 2002; Reichman et al. 2004, 2005). Nevertheless, many more families did not take up the program even when they were eligible, and one likely contributing factor to the low take-up rate is the punitive nature of some program requirements. Limited knowledge of the long-term effects of these requirements hinders the capacity of states to make informed decisions regarding policy.

\footnotetext{
5 Other major reasons for welfare case closure are employment $(17.5 \%)$, not meeting eligibility criteria $(15.1 \%)$, state policy $(12.1 \%)$, voluntary closure (13.4\%), and other sanctions (9\%).
} 
This study addresses these two limitations by following low-educated single mothers (members of the likely affected population) until 10 years after TANF implementation and then examining associations between state requirement stringencies and long-term welfare use, labor supply, and income trajectories.

\section{Mechanisms}

More stringent sanctions on noncompliance with work requirements and shorter time limits may reduce welfare use and increase employment and earnings in several ways. First, in terms of sanctions, severe sanctions will reduce welfare caseloads due to the dropping of noncompliant recipients from the welfare rolls. Adults in sanctioned families may increase labor supply to recover from the sanction and make up for the loss of income due to the sanction. Non-sanctioned welfare recipients in states with more stringent sanctions may also engage in work activities more consistently to avoid the financial penalty of sanctions or to avoid dealing with bureaucracies to recover from a sanction (Grogger and Karoly 2005). In addition, other nonrecipients eligible for welfare may choose to be more self-reliant and not apply for welfare to avoid the complications of facing work requirements and sanctions (Pavetti et al. 2003). In short, current welfare recipients, sanctioned families, and nonrecipients eligible for welfare may all increase their levels of labor supply and use welfare at a lower rate when facing stringent sanction requirements.

Second, people eligible for welfare in states with shorter time limits may also reduce their welfare use and increase employment. Responding to time limits, welfare recipients who have reached their time limit will be forced to leave the TANF welfare roll and will have to work more. Current welfare recipients and individuals who are eligible but not yet receiving welfare will try to work more and "bank" the limited time quota for the unknown future (Grogger and Karoly 2005; Ziliak 2016).

In summary, in the short term, after the welfare reform, when most families had not yet exhausted their time limits for receiving benefits, welfare-eligible individuals living in stringent regimes were likely to work more, earn more, and use welfare less because TANF benefits are a less dependable source of financial support in stringent states, where it is easier to be sanctioned and the time limit quota is sooner exhausted (Grogger and Karoly 2005).

These short-term behavioral effects could result in longterm effects because if potential welfare recipients work more in the short term, their levels of human capital will increase through accumulated job experience. In addition, potential welfare recipients may invest more time in education when anticipating welfare as an undependable source of income in the future. ${ }^{6}$ Specifically, their human capital in the long term is a function of their initial human capital level, work history, and hours worked (Ziliak 2016). This increase in human capital will lead to higher future wages among those who are induced to work more, work more stably, or study more in the short term (Ziliak 2016). Based on this mechanism, wages for low-income individuals living in stringent states are likely to be higher in the long term, as stringent policies lead to higher levels of labor supply. Additionally, the increase in human capital improves individuals' chances of securing a job that offers more work hours and being less dependent on welfare programs in the long term. However, for welfare-eligible individuals who engage mostly in jobs without a prospect of a wage increase, the increase in employment could not translate into higher earnings and income in the long term. Additionally, the employment and earnings of welfare-eligible individuals facing barriers to work would not be able to grow in either the short or the long term.

One may argue that, in the long term, individuals in states with any time limit could have reached their time limit, making welfare no longer an option and forcing everyone to be more economically self-sufficient. Therefore, there are unlikely to be differences in levels of economic self-sufficiency across stringent and non-stringent states in the long term. However, evidence suggests that many families do not use up their time limits; instead, they portion their welfare time quota (Farrell et al. 2008). Reaching the time limit accounts for only $2 \%$ of welfare case closures each month, and individuals facing harsher sanctions or shorter time limit policies are not more likely to reach their time limits (Farrell et al. 2008; Loprest 2012). Therefore, state TANF requirements still affect many families in the long term, as welfare remains an alternative income source. In addition, the assumption that individuals will work if welfare is not available is challenged by the presence of families that are "disconnected"-not working and not receiving welfare (Turner et al. 2006; Blank and Kovak 2009). Even when families exhaust their time limits, they may not pursue employment. In summary, the intuition that in the long term, individuals in stringent and non-stringent states will all exhaust their benefits and pursue work loses sight of the complexity of

\footnotetext{
${ }^{6}$ Although welfare reform reduced high school dropout rates among teenage girls, there is mixed empirical evidence regarding whether welfare reform impacts college education. Findings from some studies do not suggest that welfare reform increased enrollment in college education or vocational education among adult female potential welfare recipients (Dave et al. 2011, 2012; Jacobs and Winslow 2003), while the findings from Kim (2012) suggested that the reform decreased full-time enrollment in 2- and 4-year college between 1996 and 2002 but increased part-time enrollment in both 2and 4-year colleges between 2003 and 2008.
} 
family behavioral responses. The lack of evidence on the long-term trajectories of welfare use, labor supply, and income across stringent and non-stringent states necessitates the inquiry of this study. If behavioral responses to welfare requirements are short-lived and not sustained, social assistance systems should resort to other strategies to support the poor in achieving economic self-sufficiency.

Based on these mechanisms, I hypothesize that, compared with those not facing stringent requirements, lowskilled single mothers facing relatively stringent state TANF requirements are more likely to work more, use welfare programs less, and earn more, in both the short and long terms.

\section{Methods and Design}

\section{Data}

This study uses nationally representative data from the Survey of Income and Program Participation (SIPP) 1996, 2001, and 2004 panels. Each panel lasted 3 to 4 years, and respondents were interviewed every 4 months to collect employment, income, and program participation information from the previous 4 months. The three nonoverlapping panels are stacked together to observe the trajectories of families from 1995 to 2007, a period covering 1-2 years prior to and 10 years after TANF implementation. ${ }^{7}$ Although it would have been ideal to trace even longerterm trajectories after 2007, the Great Recession and subsequent changes in TANF policy rules complicate the identification of long-term trajectories in the post-2008 period. ${ }^{8}$ This study examines the impacts of TANF policies on women who had not received any college education (a high school degree or less) at the time of policy implementation (described in the sample section below), and information from subsequent panels serves as the follow-up for women observed in the 1996 panel. I summarize the

\footnotetext{
7 This study could not cover more years of observations prior to the welfare reform due to the redesign of the SIPP in 1996. Panels prior to the 1996 panel are not completely comparable to the panels since 1996. Additionally, since the identification of treatment and comparison respondents is based on sample characteristics at the time of the welfare reform (please see the Sample section), panels prior to 1996 could not prospectively provide this information. Nevertheless, other studies evaluating impacts of welfare reform have also utilized data starting in 1995 (e.g., Potochnick 2016).

${ }^{8}$ Not including data after 2008 limited the possibility of describing associations between TANF policy characteristics and outcomes during the Great Recession period in this study. However, since the focus of this study is to examine the associations between TANF policy stringencies and long-run outcomes, the priority was on covering a period with steady policy characteristics and fewer external environment changes, so I controlled for economic cycles using unemployment rates in the analytic models.
}

SIPP data into annual information to address the seam bias in the SIPP data (Moore 2008). Annual information also helps depict trends over time, avoiding the volatile fluctuations in earnings, labor supply, and program participation status that would have arisen had the data been structured monthly or quarterly. The SIPP is an ideal dataset for this study for three reasons. First, it provides rich information on labor force performance, welfare usage, and sociodemographic characteristics. Second, topical modules on fertility history, marital history, education and training history, and migration history provide crucial information for this study in regard to identifying individuals most likely to be affected by the welfare reform. This information is not available in other major national household surveys collecting employment and income information, such as the Current Population Survey (CPS) or the American Community Survey. Third, the SIPP is known to have lower underreporting rates of welfare participation rates when compared to the CPS and Panel Study of Income Dynamics (Meyer et al. 2009). Fourth, the SIPP tracks individuals who moved out of households at their new addresses, which is beneficial for studying long-term trajectories.

\section{Sample}

Individuals most likely to be affected by TANF policies are unmarried mothers with low levels of education (Kaushal and Kaestner 2001). It has been shown that $94 \%$ of TANF recipients had 12 or fewer years of education and $87 \%$ were not married (ACF 2012). The affected group or treatment group in this study is hence defined as unmarried mothers with a high school degree or lower levels of education. The comparison group is married mothers with a high school degree or lower levels of education. Specifically, I retain samples who are female, were not born abroad, ${ }^{9}$ have lived in their current state of residence since before 1996, and did not move during the panel (reasons detailed in the "Empirical strategies" section). I exclude individual observations from years in which samples were enrolled in school for more than one-third of the observed months in a year. ${ }^{10}$ Additionally, utilizing the individual history information collected in the SIPP topical module enables this study to restrict the samples to women who

\footnotetext{
${ }_{9}$ Most states changed their TANF eligibility requirements for immigrants during the study period, restricting the possibility of comparing long-term trajectories across states adopting various policies.

${ }^{10} \mathrm{I}$ tested whether single mothers in states with stringent policies were more likely to enroll in school and found that stringent policies were not statistically significantly associated with higher enrollment rates. In addition, the difference in enrollment rates between single and married mothers was not statistically significant.
} 
were aged 18-45 years, had a child below 18 years of age, and had a high school degree or a lower level of education at the time of TANF implementation in a given state. The marital status used to define the treatment and comparison groups is also based on marital history information that indicates marital status at the time of TANF implementation in a given state. For instance, at the end of the 2004 panel (year 2007), the age range of mothers was 30-57, and some of the unmarried mothers may have become married, acquired a college degree, or had children aged older than 18 years. ${ }^{11}$ The inclusion criteria are only imposed on mothers' characteristics at the time of policy implementation. In total, 3995 unmarried mothers (or 14,528 observations) and 6214 married mothers (or 23,618 observations) met the inclusion criteria. Another comparison group used in prior studies on welfare reform was unmarried women without children. This is not an ideal comparison group in this study focusing on long-term trajectories because some unmarried women without children at the time of TANF implementation gave birth in the subsequent period, and child birth is a stronger driver of a decrease in labor supply when compared to a change in marital status (Cohen and Blanchi 1999).

\section{Measures}

The main outcomes of this study capture three dimensions: welfare participation (participation in TANF and other welfare programs, such as the Supplemental Nutrition Assistance Program [SNAP] and Supplemental Security Income [SSI]), labor supply (employment status and average monthly hours worked), and income (average monthly earnings and total family income). Furthermore, this study examines one additional outcome: financial independence. Financial independence is defined as not receiving financial support from relatives, friends, or welfare programs, such as TANF, SNAP, and SSI. This outcome investigates whether or not families are financially independent from public and private support.

The dependent variables are coded using the following definitions. First, TANF participation is defined as receiving TANF in any month of the year. Second, SNAP and SSI participation is defined as receiving any of these benefits in any month of the year. Third, employment status is coded as 1 when a person worked for some hours at any

\footnotetext{
${ }^{11}$ I tested whether single mothers in states with stringent policies were more likely to acquire higher education degrees and found that stringent policies were not associated with increased educational attainment. Therefore, the findings of this study are not driven by effects of stringent policies on increasing education attainment. This result is consistent with the results of prior studies that found a null effect of welfare reform on college education or vocational education (Dave et al. 2011, 2012).
}

time in a year and 0 when a person did not work in a year. Fourth, monthly hours worked is constructed by multiplying the usual hours worked in a week and weeks worked in that month and averaging the monthly hours worked in that year. Fifth, log monthly total earnings are calculated through averaging monthly earnings information in a given year and then taking the log of the average monthly earnings. Sixth, log average monthly family income is calculated by averaging monthly family income (including earned income, transfer income, property income) information in a given year and then taking the log of the average monthly family income. Earnings and family income data are expressed in January 1996 currency using the Consumer Price Index. Seventh, financial independence is coded as 1 if the respondent did not receive any money from relatives, friends, TANF, SNAP, or SSI and 0 otherwise.

The main independent variables are the time indicator for long-term effects (years since state TANF implementation) and the TANF policy stringency measure. The first key independent variable is years since policy implementation or years since policy influence (YPI). This variable is the number of years relative to the timing of TANF implementation in a given state. ${ }^{12}$ According to the study hypothesis, as time elapses since the policy implementation, if stringent TANF requirements are effective in promoting financial self-reliance, the overall trend in labor force participation and earnings will be more positive or less negative, and welfare participation will be more negative in stringent states than in other states, holding all other factors constant.

The second key independent variables, as described in the TANF policy introduction section, are measures of the stringencies of two state TANF policies: time limits and sanctions on noncompliance with work requirements. For the time limit policy, when a state has a time limit of less than 60 months for the majority of the years during the study period, this state is coded as 1 ; otherwise, it is coded as 0 . For the sanction policy, when a state imposes sanctions on the full family at the initial incidence of noncompliance with work requirements for the majority of years during the study period, this state is coded as 1 , and otherwise $0 .{ }^{13}$ Table 1 details the policy stringency

\footnotetext{
12 For example, Colorado implemented its state TANF policies in July 1997. YPI is coded as -1 for July 1996 to June 1997, 0 for July 1997 to June 1998,1 for July 1998 to June $1999, \ldots$ and 9 for July 2006 to June 2007. The first states that implemented TANF were Massachusetts and Vermont in September 1996, and the last state to implement TANF was California in January 1998. YPI was coded relative to the timing of implementation specific to a state.

${ }^{13}$ If a state has more than one TANF program, I use information from the program covering the majority of welfare recipients. Respondents from North Dakota, South Dakota, and Wyoming between 1996 and 2003 are dropped from the sample because the
} 
classification of each state, and Fig. 1 shows the policy features across years. ${ }^{14}$ The data source for this variable is the Urban Institute Welfare Rules Database. I coded their textual data into numeric form.

This study additionally controls for individual characteristics and the state economic environment. Individuallevel controls include time-invariant characteristics, such as single mothers' race (White [ref.], Black, Hispanic, and other race), the age of the youngest child in the panel (0-2 [ref.], $>2$ to $<6,6$ to $<12$, or 12 to 18 years), ${ }^{15}$ and time-varying characteristics, such as age (18-24 [ref.], $25-29,30-34,35-39,40-45,45-49$, or $50-57$ years), marital status (married or not married [ref.]), number of children $(0,1,2$ [ref.], or 3 or more), and household size (1, 2,3 or 4 [ref.], or 5 or more). ${ }^{16}$ The state environment is measured by a range of state characteristics in a given year, including state unemployment rates, state EITC maximum benefits as percent of federal EITC (Tax Credits for Workers and Their Families 2015), and a range of TANF state policy characteristics (e.g., maximum income eligibility for a family of three, maximum benefits for a family of three with no income, whether or not a family cap policy exists, age of a child [in months] until which the mother could be exempted from work requirements), and state fixed effects.

\section{Empirical Strategies}

There are five major factors that may confound the relationships between welfare stringency in time limits and sanctions and the observed differences in welfare use, labor supply, and income: preexisting differences between states that adopted stringent policies and those that did not,

\footnotetext{
Footnote 13 continued

SIPP collapsed these states into the same category in the 1996 and 2001 panels, and these states have different TANF stringency levels. Maine and Vermont were collapsed into one category by the SIPP. They remain in the sample because these two states share similar TANF policy stringency.

14 Specific state sanction and time limit policies by year are presented in Appendix Tables 19 and 20. Given that some states changed time limit or sanction policy features during the study period (1995 to 2007), as shown in the changes in color within a group in Fig. 1, I conducted a sensitivity analysis on states that did not change policy features throughout this period to rule out the potential influence of these policy changes; the results are presented in Appendix 2 Tables.

15 To control for the number of children as a categorical variable, I coded the age of the youngest child as a time-invariant variable. Otherwise, the two variables will have the colinear problem.

${ }^{16}$ In sensitivity analyses, I exclude controls of individual demographic characteristics, as family formation and fertility patterns may be affected by TANF policies. Results without these controls are qualitatively the same as the findings presented in this paper. The presented main findings include demographic controls to account for differential family composition trends across states.
}

differences due to changes in economic conditions and policies over time, cross-state migration in response to policies, waiver policies, and states that changed TANF policy rules during the study period. First, states' decisions on TANF policy rules are often driven by various state characteristics, including economic circumstances, political ideology, or racial composition (De Jong et al 2006), and individual welfare use, labor supply, and income trajectories are embedded in state environments. To adjust for preexisting differences between states that adopted stringent policies and those that did not, I use state fixed effects models to address this source of bias. State fixed effects control for state differences that are constant over time.

Second, time-variant changes across states are another factor that may confound the trajectories observed in this study. To address this problem, I control for state unemployment rates in each responding state and year to account for influences of state economic environments. In addition, as mentioned above, several time-variant state policy characteristics are controlled for: state EITC maximum benefits as percent of federal EITC (Tax Credits for Workers and Their Families 2015) and a range of TANF state policy characteristics. ${ }^{17}$ In sensitivity analyses, I additionally control for state SNAP policy characteristics (described in detail in the sensitivity analysis section). This modeling approach helps ensure that the associations between time limits and sanction policies are not confounded by other observable economic and policy characteristics. Furthermore, I control for individual time-variant characteristics, such as marital status and household composition, to account for differential trends in marital and fertility patterns across stringent and non-stringent states. ${ }^{18}$ Despite these attempts, there could still be other unobserved time-variant factors correlated with state policy stringencies that affect the association between stringency levels and long-term welfare use, labor supply, and income trajectories. I adopt the DDD design to account for unobserved time-variant state characteristics (e.g., childcare resources) that similarly affect both unmarried and married low-educated mothers. In addition, I include a model that controls for state-specific linear trend, which accounts for

\footnotetext{
${ }^{17}$ Specifically, these TANF state policy characteristics include maximum income eligibility for a family of three, maximum benefits for a family of three with no income, whether the state has a family cap policy, and age of a child (in months) until which the mother could be exempted from work requirements.

${ }^{18}$ Excluding controls of time-variant marital and fertility variables yielded results that are qualitatively the same as the findings presented in this paper. The presented main findings include demographic controls to account for differential family composition trends across states.
} 
Table 1 State TANF policy stringency measures

\begin{tabular}{|c|c|c|}
\hline State & Full sanction & $<60$ time limi \\
\hline \multicolumn{3}{|l|}{ Alabama } \\
\hline \multicolumn{3}{|l|}{ Alaska } \\
\hline \multicolumn{3}{|l|}{ Arizona } \\
\hline Arkansas & & $\bigcirc$ \\
\hline \multicolumn{3}{|l|}{ California } \\
\hline \multicolumn{3}{|l|}{ Colorado } \\
\hline Connecticut & & $\bigcirc$ \\
\hline Delaware & & O \\
\hline \multicolumn{3}{|c|}{ District of Columbia } \\
\hline Florida & 0 & $\bigcirc$ \\
\hline Georgia & & $\bigcirc$ \\
\hline Hawaii & 0 & \\
\hline Idaho & 0 & $\bigcirc$ \\
\hline \multicolumn{3}{|l|}{ Illinois } \\
\hline \multicolumn{3}{|l|}{ Indiana } \\
\hline Iowa & 0 & \\
\hline Kansas & O & \\
\hline \multicolumn{3}{|l|}{ Kentucky } \\
\hline \multicolumn{3}{|l|}{ Louisiana } \\
\hline \multicolumn{3}{|l|}{ Maine } \\
\hline Maryland & 0 & \\
\hline \multicolumn{3}{|l|}{ Massachusetts } \\
\hline Michigan & O & \\
\hline \multicolumn{3}{|l|}{ Minnesota } \\
\hline Mississippi & 0 & \\
\hline \multicolumn{3}{|l|}{ Missouri } \\
\hline \multicolumn{3}{|l|}{ Montana } \\
\hline Nebraska & $\bigcirc$ & \\
\hline \multicolumn{3}{|l|}{ Nevada } \\
\hline \multicolumn{3}{|l|}{ New Hampshire } \\
\hline \multicolumn{3}{|l|}{ New Jersey } \\
\hline \multicolumn{3}{|l|}{ New Mexico } \\
\hline \multicolumn{3}{|l|}{ New York } \\
\hline \multicolumn{3}{|l|}{ North Carolina } \\
\hline \multicolumn{3}{|l|}{ North Dakota } \\
\hline \multicolumn{3}{|l|}{ Ohio } \\
\hline Oklahoma & ○ & \\
\hline Oregon & & \\
\hline Pennsylvania & & \\
\hline Rhode Island & & \\
\hline South Carolina & 0 & \\
\hline South Dakota & & \\
\hline Tennessee & $\bigcirc$ & \\
\hline Texas & & \\
\hline Utah & & O \\
\hline Vermont & & \\
\hline Virginia & 0 & \\
\hline Washington & & \\
\hline
\end{tabular}

Table 1 (continued)

\begin{tabular}{lll}
\hline State & Full sanction & $<60$ time limit \\
\hline West Virginia & & \\
Wisconsin & & \\
Wyoming & 0 & 7 \\
Total & 14 & \\
\hline
\end{tabular}

the state trend of an outcome among low-educated mothers. $^{19}$

Third, in terms of cross-state migration, state TANF policies may encourage interstate migration, and this may bias the trajectories observed in this study. Studies have documented that lenient welfare policies may attract disadvantaged families to move into the state (McKinnish 2005), and stringent policies may push low-income families to migrate out of the state (De Jong et al. 2005). Restricting the sample to those who had lived in a state prior to the welfare reform allows this study to exclude respondents who migrated into states that did not adopt stringent policies after the reform and to more accurately capture long-term relationships. ${ }^{20}$ However, this residence restriction cannot account for effects from disadvantaged mothers who moved out of a state with stringent policies, so observed trajectories of stringent policies might underestimate welfare use and overestimate labor supply and earned income. Nevertheless, the magnitude of migration as a result of welfare policies is found to be small (Bailey 2005; Goodman 2017; Kaushal 2005; Schram et al. 1998). Additionally, excluding respondents who moved to another state after the reform is necessary when measuring the long-term patterns for another reason. For a person who moves from one type of state to another, his or her welfare use, labor supply, and income trajectories over time would not reflect behavioral responses to a particular type of policy. For example, if a person moves out of a state with a shorter time limit or a stricter sanction during the fifth year after TANF policy implementation, his or her outcome during the sixth year will not reflect his or her response to a

\footnotetext{
19 In execution, I create a trend variable (with 1995 coded as 0, 1996 as 1 , and so on) and interact this trend variable with each state dummy variable. I include these 50 trend and state interactions in the regression.

20 The cutoff of 1996 is selected because the PRWORA was passed in 1996. In sensitivity analyses, I change the cutoff to 1991, as states started to implement AFDC waiver policies as early as 1992 (assuming that no one could foresee state TANF policy choices before 1992). The results, which are presented in Appendix 2 Tables, were qualitatively the same as the main findings presented in this paper.
} 


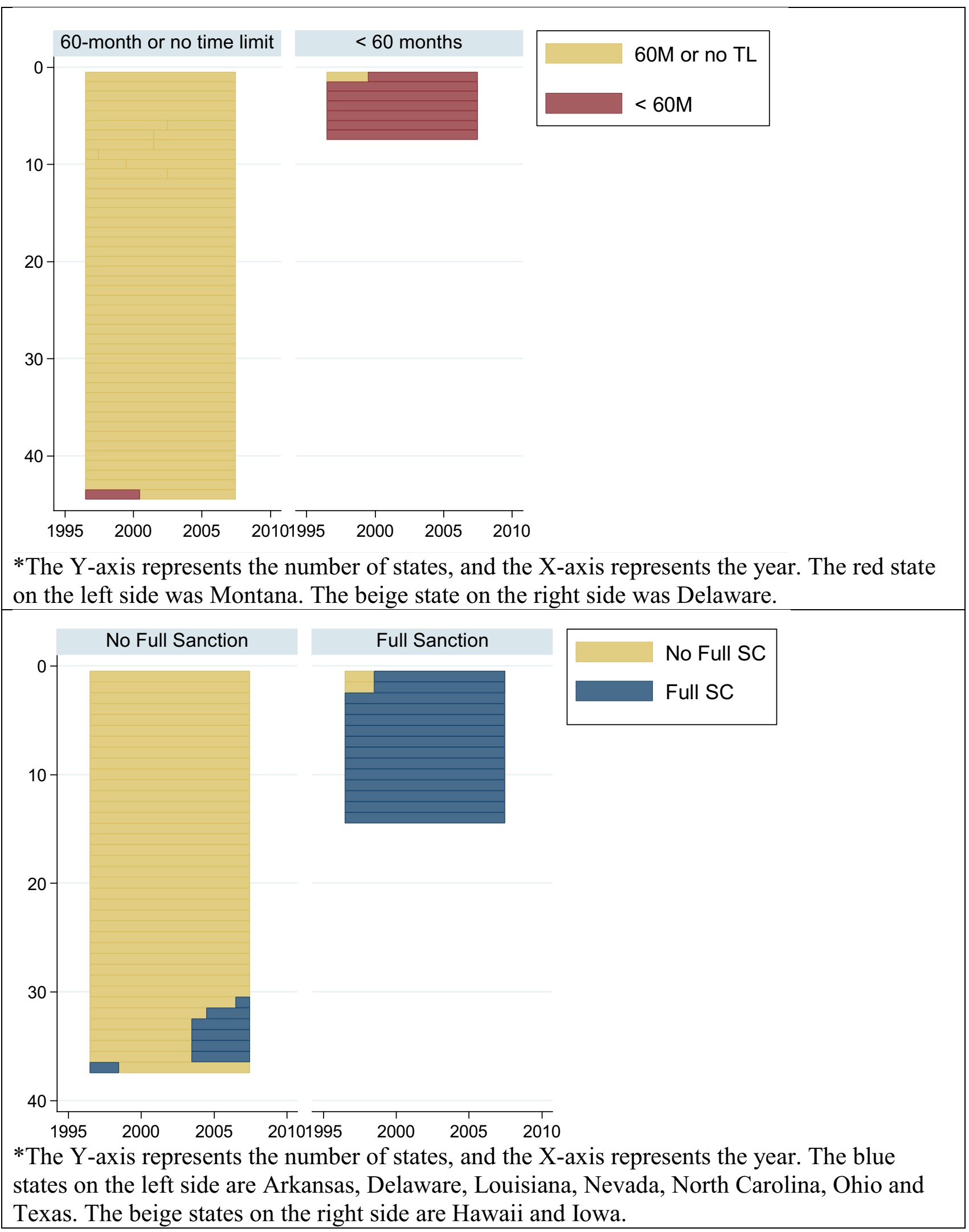

Fig. 1 Policy stringencies in time limits and sanction policies between 1997 and 2007 
particular policy in the sixth year. The residence restriction employed in this study allows the proper tracking of individual trajectories over time. ${ }^{21}$

Fourth, as mentioned earlier, many states implemented waiver policies prior to the welfare reform, which may affect the trajectories examined in this study. For instance, five states adopted time limits shorter than 60 months, and two states adopted full-family sanction policies between 1993 and 1995 (Grogger and Karoly 2005). Although requirements in these states may have changed after the reform, the work and welfare use trajectories of single mothers since the reform likely differ from those of their counterparts living in states without waiver policies, as those living in states with waiver policies were exposed to components of the reform earlier. I address this potential bias through two ways. First, I control for state fixed effects in all models, which adjust for fixed characteristics related to the adoption of waiver policies. Second, in one model, I exclude states that adopted any waiver policy prior to 1996 from the analyses.

Fifth, as shown in Fig. 1, a number of states changed TANF policy rules during the study period. In terms of time limits, Montana transitioned from having a time limit below 60 months to having a time limit of 60 months, and Delaware transitioned into having a time limit below 60 months. With respect to sanctions, seven states that did not have full sanctions in the majority of years during the study period adopted full sanctions in other years, and two states transitioned into having full sanctions. I classified these states based on their policy environments in most years during the study period, but these transitions may affect the trajectories examined in this study. Therefore, in sensitivity analyses, I conduct additional analyses excluding states that experienced transitions in time limit and sanction policies during the study period, and the results are presented in Appendix 2 Tables.

In this study, the samples of focus are low-skilled single mothers, regardless of their status in regard to TANF benefits recipiency. Mothers not receiving TANF are included in this study for two reasons. First, the effect of the TANF policy requirements may or may not go through the actual participation in TANF. Taking TANF nonparticipants as an example, as described in the mechanisms section, they may prefer to work more and not use welfare to save their time limit quota or to avoid the hassle of

\footnotetext{
21 The two residence restriction criteria (those who arrived in the state of residence before 1996 and did not move during the panel) exclude $11.7 \%$ of the single low-educated mother sample. In the analytic dataset, when comparing low-educated single mothers with married mothers in the initial five years after the reform, single mothers in states with stringent work sanction or time limit policies were not more likely to move than those living in states without stringent policies.
}

dealing with TANF behavioral requirements. Behavioral responses to policy characteristics may not go through the actual program participation. Second, TANF policy stringencies are correlated with program participation rates. Participants in states with more stringent requirements are, on average, more disadvantaged than participants in states without stringent requirements; for example, they tend to have worse health and higher rates of disability (Moffitt et al. 2001; Frogner et al. 2009). If the samples that receive TANF benefits were the focus, the comparison between states with or without stringent policies would be a case of comparing apples and oranges. Both reasons point to the importance of including both TANF-participating and nonparticipating mothers, so this study could capture the full range of relationships between TANF policy stringencies and outcomes.

I adopt the DDD design to account for unobservable time-variant factors that correlate with outcomes or TANF policy characteristics. Following various studies, low-educated unmarried mothers at the time of TANF policy implementation are selected to be the treatment group, and their married mother ${ }^{22}$ counterparts are chosen as the comparison group (Bitler et al. 2005; Kaushal and Kaestner 2001). Married mothers were less affected because married mothers likely had household incomes that were too high to qualify for TANF, so their outcomes may serve as approximate reference points in understanding the extent of the policy effects on single mothers. One complication of the longitudinal analysis is that mothers' marital status may change over time. Mothers who were married at the time of the welfare reform may later separate or divorce from their spouses, and single mothers may become married later and have a lower likelihood of qualifying for TANF. I control for time-varying marital status, number of children, and household size to account for the differential trends in marriage across states over time. ${ }^{23}$ The first difference is

\footnotetext{
${ }^{22}$ Married mothers may be affected, to a small extent, by the welfare reform because they were eligible to apply for TANF in many states. In 1999, 18 states imposed additional eligibility rules beyond the standard eligibility criteria for two-parent households, while the remaining 32 did not have additional rules (Rowe 2000). In 2007, the last year covered by this study, 12 states imposed additional eligibility rules for two-parent households (Rowe et al. 2008). Among the states that imposed additional rules in 1999 and 2007, North Dakota did not allow two-parent households to receive TANF (Rowe 2000; Rowe et al. Rowe). In 2014, nine states imposed additional eligibility rules for two-parent households, and three states (Louisiana, New Hampshire, and North Dakota) did not allow two-parent households to receive TANF (Huber et al. 2015). However, the effect is expected to be small because households with married couples likely had higher incomes and hence found it more difficult to meet the income eligibility criteria to receive TANF.

${ }^{23}$ The results from models without these control variables were qualitatively the same as the results presented in this paper. The results are available upon request.
} 
the difference in outcomes $(\mathrm{Y})$ before and after the welfare reform $\left(Y_{2}-Y_{1}\right)$, the second difference is between unmarried (U) and married (M) mothers $\left(\left[Y_{U 2}-Y_{U 1}-Y_{M 2}-Y_{M 1}\right]\right)$, and the third difference is between states with stringent policies (S) and states without stringent policies (more lenient; L) $\left\{\left(\left[Y_{S U 2}-Y_{S U 1}\right)\right]-\right.$ $\left.\left.\left.\left[Y_{S M 2}-Y_{S M 1}\right]\right)-\left(\left[Y_{L U 2}-Y_{L U 1}\right)\right]-\left[Y_{L M 2}-Y_{L M 1}\right]\right)\right\}$. The validity of the difference-in-difference research design requires that the trends in outcomes between the treatment and comparison groups would have been similar in the absence of policy. I test this parallel trend assumption by comparing trends in outcomes between married and unmarried mothers prior to the implementation of TANF. The results presented in Appendix Table 10 indicate that married mothers are a suitable comparison group, as suggested by prior studies (Bitler et al. 2005; Kaushal and Kaestner 2001). ${ }^{24}$ One may argue that single and married mothers may differ in their patterns of outcomes as they and their children grow older. To address this concern, I also present the first difference results in Appendix 2 Tables, allowing the examination of whether the results are driven by changes in the treatment or comparison group mothers.

I use two types of models in the empirical analysis. First, for the earned income and work hours outcomes, I use the Heckman selection model (detailed in the last part of the empirical strategies section). Second, for all other outcomes, I use a three-level multilevel model to examine the differential long-term welfare use, labor supply, and income progress between low-skilled unmarried and married mothers in states with stringent time limits and sanctions and states without. Multilevel models have the strength of adjusting for the clustering nature of data and allowing the standard errors to be more robust (Raudenbush and Bryk 2002). In this study, observations at each time point/in each year (level 1) are nested within individuals (level 2), and individuals are nested within states (level 3). Below, I describe the model for each level. The level 1 model is as follows:

$$
\begin{aligned}
& Y_{t i s}=\beta_{0 i s}+\sum_{t i s} \beta_{1 i s} Y P\left(0, \sigma_{\varepsilon}^{2}\right) \\
& \quad \varepsilon_{t i s}+\sum \beta_{2 i s} X_{t i s}+\sum \beta_{3 i s} S_{t i s}+\varepsilon_{t i s}
\end{aligned}
$$

where $Y_{\text {tis }}$ is the outcome for individual $i$ in state $s$ at time $t$. Each outcome is regressed on time categories $\left(Y P I_{t i s}\right)$, so a

\footnotetext{
${ }^{24}$ Ideally, this study could include more years of data prior to TANF implementation, but the SIPP 1996 panel contains information since only 1995 . Therefore, I have data for only 0-9 quarters before TANF policy implementation in a given state. Nevertheless, the available multiple time points ( 9 quarters) enable the examination of parallel trend testing. Furthermore, the selection of a comparison group is supported by the rich body of welfare reform literature using married mothers as the comparison group when the difference-in-difference methodology was adopted.
}

vector of $\beta_{1 i s}$ captures how the outcomes change with years elapsed since TANF implementation. ${ }^{25} X_{\text {tis }}$ represents a vector of time-variant individual or household characteristics, ${ }^{26}$ and $S_{t i s}$ represents a vector of state time-variant characteristics in state $s$ at time $t^{27} \beta_{0 i s}$ is the mean of an outcome across time points for person $i$ in state $s$, and the error term is noted as $\varepsilon_{t i s}$, which is assumed to be independent and to conform to normal distribution, with a mean of 0 and variance of $\sigma_{\varepsilon}^{2}$. The level 2 model is as follows:

$\beta_{0_{i s}}=\gamma_{0_{0 s}}+\gamma_{0_{1 s}}$ Treat $_{i s}+\sum \gamma_{0_{2 s}} X_{i s}+\zeta_{0_{i s}} \zeta_{0_{i s}} \sim N\left(0, \sigma_{\zeta_{0}}^{2}\right)$

$\beta_{1 i s}=\gamma_{10 s}+\gamma_{11 s}$ Treat $_{\text {is }}$

$\beta_{2 i s}=\gamma_{20 s}$

$\beta_{3 i s}=\gamma_{30 s}+\gamma_{31 s}$ Treat $_{i s}$

where Treat $_{i s}$ is the treatment status, with women who were single mothers at time of TANF policy implementation in state $s$ coded as 1 and those who were married mothers coded as 0 . A vector of $X_{i s}$ represents individual time-invariant characteristics. ${ }^{28} \gamma_{00 s}$ is the mean of the outcome across individuals in state $s$, and $\zeta_{0 i s}$ represents the random intercept specific to the individual $i . \gamma_{11 s}$ are the interactions between treatment status ( Treat $_{i s}$ ) and years since policy influence categories $\left(\sum Y P I_{t i s}\right)$, and this vector of coefficients estimates the differences in outcomes between unmarried and married mothers across YPIs regardless of time limits and sanction policy characteristics. $\gamma_{31 s}$ are the interactions between treatment status $\left(\right.$ Treat $\left._{i s}\right)$ and a vector of state time-variant characteristics $\left(\sum S_{t i s}\right)$. These interactions allow coefficients for state characteristics to vary for treatment and comparison groups to account for the confounding effects of other state characteristics. The level 3 model is as follows:

$$
\begin{aligned}
& \gamma_{00 s}=b_{000}+\sum b_{001} \text { State }_{s}+\eta_{00 s} \quad \eta_{00 s} \sim N\left(0, \sigma_{\eta_{0}}^{2}\right) \\
& \gamma_{01 s}=b_{010}+b_{012} \text { FullSC }_{s}+b_{013} T L<60_{s} \\
& \gamma_{02 s}=b_{020} \\
& \gamma_{10 s}=b_{100}+b_{101} \text { FullSC }_{s}+b_{102} T L<60_{s}
\end{aligned}
$$

\footnotetext{
${ }^{25} Y \mathrm{I}_{\text {tis }}$ includes five categorical dummies of time, representing 0-1 year, 2-3 years, 4-5 years, 6-7 years, and 8-10 years since TANF implementation, with 2 to 1 year prior to TANF implementation as the reference group.

${ }^{26}$ Age categories, marital status, household size, and the number of children.

27 These include unemployment rates, state EITC benefits, and a range of TANF state policy characteristics (maximum income eligibility, maximum benefit level, family cap, and work exemption requirements). In sensitivity analyses, I also include SNAP policy characteristics in this vector.

28 These include race and age of the youngest child.
} 
$\gamma_{11 s}=b_{110}+b_{111}$ FullSC $_{s}+b_{112} T L<60_{s}$

$\gamma_{20 s}=b_{200}$

$\gamma_{30 s}=b_{300}$

$\gamma_{31 s}=b_{310}$

where $b_{000}$ is the average outcome level across states, a vector of $b_{001}$ captures state fixed effects, ${ }^{29}$ and $\eta_{00 s}$ represents state-specific random intercepts. The coefficients $b_{012}$ and $b_{013}$ represent the interactions between treatment status and the TANF policy characteristics of interest, a time limit that is shorter than 60 months $\left(T L<60_{s}\right)$ and a full sanction on noncompliance with work requirements $\left(F u l l S C_{s}\right)$. The omitted category here is states without strict time limits or full sanction policies. $b_{101}$ and $b_{102}$ represent the interactions between time limit/sanction policy characteristics with the vector of years since policy influence categories $\left(\sum Y P I_{t i s}\right)$. The main coefficients of interests in this study are $b_{111}$ and $b_{112}$ : the three-way interactions between state TANF policy stringencies $\left(F u l l S C_{s}\right.$ and $T L<60_{s}$ ), treatment status $\left(\right.$ Treat $_{i s}$ ), and years since policy influence $\left(Y P I_{t i s}\right)$. These coefficients $\left(b_{111}\right.$ and $\left.b_{112}\right)$ show whether the differences between low-skilled unmarried mothers and married mothers in welfare use, labor supply, and income trajectories vary over time by the TANF policy environment in which they live.

The level 1, 2, and 3 equations can be combined into a single equation or a composite model/reduced form, as follows:

$$
\begin{aligned}
& Y_{\text {tis }}=b_{000}+\sum b_{100} Y_{P I_{\text {tis }}}+b_{010} \text { Treat }_{i s}+\sum b_{00 .} \text { State }_{s} \\
& +\sum b_{110} Y P I_{\text {tis }} x \text { Treat }_{\text {is }}+\sum b_{101} Y P I_{\text {tis }} x \text { FullSC }_{s} \\
& +\sum b_{102} Y_{P I} I_{\text {tis }} x T L<60_{s}+\sum b_{011} \text { Treat }_{i s} x \text { FullSC }_{s} \\
& +\sum b_{012} \text { Treat }_{i s} x T L<60_{s} \\
& +\sum b_{111} \text { Treat }_{i s} x Y R S_{\text {tis }} x F_{\text {FullSC }} \\
& +\sum b_{112} \text { Treat }_{i s} x Y R S_{\text {tis }} x T L<60_{s}+\sum b_{200} X_{\text {tis }} \\
& +\sum b_{300} S_{t s}+\sum b_{310} \text { Treat }_{i s} x S_{t s}+\sum b_{020} X_{i s} \\
& +\zeta_{0 i s}+\eta_{00 s}+\varepsilon_{t i s}
\end{aligned}
$$

where vectors of $b_{111}$ and $b_{112}$ are the main coefficients of interest, which represent the cross-level interactions between TANF policy stringencies (state-level), treatment status (individual-level) and YPI categories. The vector of $b_{110}$ estimates the differences in unmarried and married

\footnotetext{
29 The TANF policy characteristics of interest, a time limit that is shorter than 60 months $\left(T L<60_{s}\right)$ and a full sanction on noncompliance with work requirements $\left(\right.$ FullSC$\left._{s}\right)$, are time-invariant state characteristics, so state fixed effects account for the main effects of these two policy characteristics.
}

low-educated mothers' trajectories of outcomes shared across all states. ${ }^{30}$

Second, for the earned income and hours worked outcomes, I use the Heckman two-step model to adjust for selection bias into employment (Heckman 1979). For instance, if more stringent policies lead to a higher employment rate, analyses of earnings or work hours would be affected by the employment rates. In the first stage, I use the same set of covariates in the DDD model as instrumental variables to predict the probability of being employed; in the second stage, in addition to including the same set of covariates, the model corrects for selection by including an explanatory variable, an inverse Mill's ratio, that predicts individuals' probability of selection into employment.

\section{Results}

Table 2 presents the descriptive statistics of the demographic characteristics and outcomes from 1 to 2 years prior to TANF implementation in a given state. Characteristics of the treatment group (single mothers) and comparison group (married mothers) are presented separately. I further delineate the characteristics by policy stringencies. There are a few observations to note. First, states with stringent TANF policies had higher proportions of respondents who were Black $(49 \%$ in states with full sanction policies and $56 \%$ in states with a time limit below 60 months) than did states without stringent policies (31\%). Second, $38 \%$ of low-educated single mothers received the AFDC prior to the welfare reform, $55 \%$ of them received food stamps, and $10 \%$ received SSI. Overall, single mothers in states that later adopted stringent TANF generally showed slightly higher rates of welfare program participation. Third, single mothers living in states that later adopted stringent TANF policies, on average, had lower monthly earnings and family income than did those living in non-stringent states.

The multilevel model results compare outcomes 1 year to 2 years before the implementation of TANF to 0 to 10 years after the welfare reform across states with full work sanctions, states with a time limit shorter than 60 months, and states without these policies (the reference

\footnotetext{
${ }^{30}$ I also estimate the results from the following first-difference model for unmarried and married mothers separately. The results are presented in Appendix 2 Tables. The coefficients of interest are $b_{101}$ and $b_{102}$.$$
\begin{aligned}
Y_{t i s}= & b_{000}+\sum b_{100} Y P I_{t i s}+\sum b_{001} \text { State }_{s}+\sum b_{101} Y_{P I} I_{t i s} x F u l l S C_{s} \\
& +\sum b_{102} Y_{t i s} x T L<60_{s}+\sum b_{200} X_{t i s}+\sum b_{300} S_{t s} \\
& +\sum b_{020} X_{i s}+\zeta_{0 i s}+\eta_{00 s}+\varepsilon_{t i s}
\end{aligned}
$$ 
Table 2 Descriptive characteristics 1 to 2 years prior to TANF implementation

\begin{tabular}{|c|c|c|c|c|c|c|}
\hline & \multicolumn{3}{|l|}{$\begin{array}{l}\text { Treatment group: } \\
\text { Single mothers }\end{array}$} & \multicolumn{3}{|l|}{$\begin{array}{l}\text { Comparison group: } \\
\text { Married mothers }\end{array}$} \\
\hline & $\begin{array}{l}\text { No full-sanction } \\
\& \text { no }<60 \text {-month } \\
\text { time limit }\end{array}$ & $\begin{array}{l}\text { Full } \\
\text { sanction }\end{array}$ & $\begin{array}{l}<60 \text {-month } \\
\text { time limit }\end{array}$ & $\begin{array}{l}\text { No full-sanction } \\
\& \text { no }<60 \text {-month } \\
\text { time limit }\end{array}$ & $\begin{array}{l}\text { Full } \\
\text { sanction }\end{array}$ & $\begin{array}{l}<60 \text {-month } \\
\text { time limit }\end{array}$ \\
\hline \multicolumn{7}{|l|}{ Demographics } \\
\hline Age & 30.79 & 30.84 & 30.69 & 33.45 & 33.51 & 32.64 \\
\hline \multicolumn{7}{|l|}{ Race } \\
\hline White & 0.53 & 0.46 & 0.37 & 0.81 & 0.82 & 0.84 \\
\hline Black & 0.31 & 0.49 & 0.56 & 0.05 & 0.14 & 0.12 \\
\hline Hispanic & 0.14 & 0.03 & 0.06 & 0.12 & 0.02 & 0.03 \\
\hline Other race & 0.02 & 0.02 & 0.00 & 0.02 & 0.01 & 0.00 \\
\hline \multicolumn{7}{|l|}{ Household size } \\
\hline 1 person & 0.00 & 0.01 & 0.01 & 0.00 & 0.00 & 0.00 \\
\hline 2 people & 0.15 & 0.17 & 0.14 & 0.01 & 0.01 & 0.01 \\
\hline 3-4 people & 0.54 & 0.54 & 0.52 & 0.65 & 0.64 & 0.65 \\
\hline 5 or more people & 0.31 & 0.29 & 0.33 & 0.34 & 0.35 & 0.34 \\
\hline \multicolumn{7}{|l|}{ Number of children } \\
\hline 0-1 child & 0.48 & 0.50 & 0.50 & 0.32 & 0.33 & 0.35 \\
\hline 2 children & 0.27 & 0.28 & 0.29 & 0.43 & 0.42 & 0.42 \\
\hline 3 or more children & 0.24 & 0.22 & 0.21 & 0.25 & 0.25 & 0.24 \\
\hline Age of the youngest child & 5.15 & 5.12 & 4.92 & 5.90 & 5.99 & 5.60 \\
\hline \multicolumn{7}{|l|}{ Outcomes } \\
\hline AFDC participation & 0.38 & 0.40 & 0.38 & 0.06 & 0.04 & 0.04 \\
\hline Food Stamp (SNAP) participation & 0.55 & 0.56 & 0.58 & 0.13 & 0.14 & 0.11 \\
\hline SSI participation & 0.10 & 0.13 & 0.15 & 0.03 & 0.02 & 0.01 \\
\hline Employed & 0.57 & 0.58 & 0.62 & 0.65 & 0.67 & 0.69 \\
\hline Monthly work hours (excluding zero) & 155 & 156 & 144 & 147 & 150 & 153 \\
\hline Average monthly earnings (excluding zero) & 1085 & 1023 & 965 & 1270 & 1150 & 1191 \\
\hline Monthly family income & 1912 & 1795 & 1810 & 3730 & 3366 & 3488 \\
\hline $\begin{array}{l}\text { Financial independence (not receiving } \\
\text { social assistance or help from relatives } \\
\text { or friends) }\end{array}$ & 0.40 & 0.38 & 0.36 & 0.84 & 0.84 & 0.88 \\
\hline
\end{tabular}

All samples are restricted to U.S.-born women aged 18-45 at the time of TANF implementation in a given state, not having any college education, having lived in the current state of residence before 1996, and not having moved during the panel. Individual observations from years in which they were enrolled in school for more than one third of the observed months in a year were excluded. Sample categorization (single mothers and married mothers) is based on the sample characteristics at the time of TANF implementation. Earning and family income values are expressed in January 1996 US dollars using the Consumer Price Index

category; standard TANF policies hereafter). Analyses were conducted on a cohort of mothers who were 18 to 45 years old and who did not have any college education at the time of TANF implementation in the given state, and this cohort was followed for 11 years after the reform. All models control for a rich set of mothers' and state characteristics as well as state fixed effects. Model (1) shows the results from the full sample; Model (2) additionally controls for year fixed effects and state-specific linear trends to further account for unobservable trends in outcomes; and Model (3) restricts the analytic sample to states that did not implement a time limit or sanction waiver policy before $1996 .^{31}$ Below, I focus on reporting findings based on Model (1) and results that were statistically significant. The results in Model (2) and Model (3) are shown in the tables to highlight the sensitivity of the findings.

\footnotetext{
31 States excluded in this model include Arizona, Delaware, Georgia, Illinois, Indiana, Iowa, Massachusetts, Michigan, Mississippi, Missouri, Nebraska, New Jersey, Oregon, South Dakota, Utah, Vermont and Virginia [Tables 14 and 15 in Grogger and Karoly (2005)].
} 
Table 3 Trajectories of TANF participation and policy stringencies

\begin{tabular}{|c|c|c|c|}
\hline & \multicolumn{3}{|c|}{ TANF participation } \\
\hline & Full sample (1) & $\begin{array}{l}\text { State-specific } \\
\text { trend } \\
(2)\end{array}$ & $\begin{array}{l}\text { States with no waiver } \\
\text { before } 1996 \text { (3) }\end{array}$ \\
\hline \multicolumn{4}{|c|}{ Years since policy influence (YPI) (reference: -2 to -1 year) } \\
\hline $0-1$ year $\times$ treat & $\begin{array}{l}-0.033 * * * \\
(0.008)\end{array}$ & $\begin{array}{l}-0.031 * * * \\
(0.008)\end{array}$ & $\begin{array}{l}-0.024 * \\
(0.010)\end{array}$ \\
\hline $2-3$ year $\times$ treat & $\begin{array}{l}-0.112^{* * *} \\
(0.010)\end{array}$ & $\begin{array}{l}-0.110 * * * \\
(0.010)\end{array}$ & $\begin{array}{l}-0.110 * * * \\
(0.012)\end{array}$ \\
\hline $4-5$ year $\times$ treat & $\begin{array}{l}-0.161 * * * \\
(0.012)\end{array}$ & $\begin{array}{l}-0.158 * * * \\
(0.012)\end{array}$ & $\begin{array}{l}-0.158 * * * \\
(0.014)\end{array}$ \\
\hline $6-7$ year $\times$ treat & $\begin{array}{l}-0.202 * * * \\
(0.013)\end{array}$ & $\begin{array}{l}-0.198 * * * \\
(0.013)\end{array}$ & $\begin{array}{l}-0.205^{* * *} \\
(0.015)\end{array}$ \\
\hline $8-10$ year $\times$ treat & $\begin{array}{l}-0.196 * * * \\
(0.014)\end{array}$ & $\begin{array}{l}-0.193 * * * \\
(0.014)\end{array}$ & $\begin{array}{l}-0.199 * * * \\
(0.016)\end{array}$ \\
\hline \multicolumn{4}{|l|}{ YPI $\times$ sanction } \\
\hline $0-1$ year $\times$ treat $\times$ full sanction & $\begin{array}{l}-0.059 * * * \\
(0.015)\end{array}$ & $\begin{array}{l}-0.060 * * * \\
(0.015)\end{array}$ & $\begin{array}{l}-0.031 \\
(0.022)\end{array}$ \\
\hline $2-3$ year $\times$ treat $\times$ full sanction & $\begin{array}{l}-0.085^{* * *} \\
(0.017)\end{array}$ & $\begin{array}{l}-0.086 * * * \\
(0.017)\end{array}$ & $\begin{array}{l}-0.035 \\
(0.025)\end{array}$ \\
\hline $4-5$ year $\times$ treat $\times$ full sanction & $\begin{array}{l}-0.030 \\
(0.023)\end{array}$ & $\begin{array}{l}-0.031 \\
(0.023)\end{array}$ & $\begin{array}{l}0.028 \\
(0.036)\end{array}$ \\
\hline $6-7$ year $\times$ treat $\times$ full sanction & $\begin{array}{l}-0.049 * \\
(0.022)\end{array}$ & $\begin{array}{l}-0.050^{*} \\
(0.022)\end{array}$ & $\begin{array}{l}0.010 \\
(0.034)\end{array}$ \\
\hline $8-10$ year $\times$ treat $\times$ full sanction & $\begin{array}{l}-0.044^{+} \\
(0.024)\end{array}$ & $\begin{array}{l}-0.045^{+} \\
(0.024)\end{array}$ & $\begin{array}{l}0.009 \\
(0.035)\end{array}$ \\
\hline \multicolumn{4}{|l|}{ YPI $\times$ time limit } \\
\hline $0-1$ year $\times$ treat $\times<60$ month & $\begin{array}{l}-0.005 \\
(0.020)\end{array}$ & $\begin{array}{l}-0.004^{\wedge \wedge} \\
(0.020)\end{array}$ & $\begin{array}{l}-0.029 \\
(0.029)\end{array}$ \\
\hline $2-3$ year $\times$ treat $x<60$ month & $\begin{array}{l}-0.086^{* * * *} \\
(0.022)\end{array}$ & $\begin{array}{l}-0.084 * * * \\
(0.023)\end{array}$ & $\begin{array}{l}-0.058^{+} \\
(0.033)\end{array}$ \\
\hline $4-5$ year $\times$ treat $\times<60$ month & $\begin{array}{l}-0.027 \\
(0.030)\end{array}$ & $\begin{array}{l}-0.024 \\
(0.030)\end{array}$ & $\begin{array}{l}-0.072 \\
(0.045)\end{array}$ \\
\hline $6-7$ year $\times$ Treat $\times<60$ month & $\begin{array}{l}-0.038 \\
(0.030)\end{array}$ & $\begin{array}{l}-0.031 \\
(0.030)\end{array}$ & $\begin{array}{l}-0.086^{*} \\
(0.044)\end{array}$ \\
\hline $8-10$ year $\times$ treat $\times<60$ month & $\begin{array}{l}-0.068 * \\
(0.033)\end{array}$ & $\begin{array}{l}-0.056^{+} \\
(0.033)\end{array}$ & $\begin{array}{l}-0.125^{* * \wedge \wedge} \\
(0.047)\end{array}$ \\
\hline Treat & $\begin{array}{l}-0.319 * * * \\
(0.085)\end{array}$ & $\begin{array}{l}-0.325^{* * *} \\
(0.085)\end{array}$ & $\begin{array}{l}-0.341 * * * \\
(0.100)\end{array}$ \\
\hline Treat $\times$ full sanction & $\begin{array}{l}0.055^{* *} \\
(0.019)\end{array}$ & $\begin{array}{l}0.056 * * \\
(0.019)\end{array}$ & $\begin{array}{l}0.007 \\
(0.027)\end{array}$ \\
\hline Treat $\times<60$ month & $\begin{array}{l}0.017 \\
(0.024)\end{array}$ & $\begin{array}{l}0.014 \\
(0.024)\end{array}$ & $\begin{array}{l}0.069^{+} \\
(0.035)\end{array}$ \\
\hline Constant & $\begin{array}{l}0.658 * * \\
(0.209)\end{array}$ & $\begin{array}{l}0.410 \\
(0.251)\end{array}$ & $\begin{array}{l}0.565^{*} \\
(0.230)\end{array}$ \\
\hline \multicolumn{4}{|l|}{ Variance terms } \\
\hline State intercepts & 0.000 & 0.000 & 0.000 \\
\hline Ind. intercepts & 0.036 & 0.036 & 0.039 \\
\hline Residuals & 0.027 & 0.027 & 0.027 \\
\hline
\end{tabular}


Table 3 (continued)

TANF participation

Full sample (1)
State-specific

trend

(2)
States with no waiver

before 1996 (3)
$\mathrm{N}$
38,146
38,146
25,111

Each column is a separate linear multilevel regression model. All samples are restricted to U.S.-born women aged 18-45 at the time of TANF implementation in a given state, not having any college education, having lived in the current state of residence before 1996, and not having moved during the panel. Individual observations from years in which they were enrolled in school for more than one-third of the observed months in a year were excluded. Sample categorization (single mothers and married mothers) is based on the sample characteristics at time of TANF implementation, and the Treat variable indicates whether the respondent is a single mother (the reference group is married mothers). In addition to the variables shown above in the table, all models control for women's race (White (ref.), Black, Hispanic, and other race), age of the youngest child in the panel ( $0-2$ (ref.), $>2$ to $<6,6$ to $<12,12$ to 18$)$, and time-variant characteristics, including age in categories [18-24 (ref.), 25-29, 30-34, 35-39, 40-45, 45-49, 50-57], whether married, household size (1, 2, 3 or 4 (ref.), 5 or more), number of children [0, 1, 2 (ref.), and 3 or more], unemployment rates in state s and year t, state EITC maximum benefits as percent of federal EITC in state s and year t, a range of TANF state policy characteristics in state $\mathrm{s}$ and year $\mathrm{t}$ [including maximum income eligibility for a family of three, maximum benefits for a family of three with no income, whether or not they have a family cap policy, age of a child (in months) until which a mother could be exempted from work requirements], the interactions between the treatment indicator and other state-level variables (unemployment rates, state EITC maximum benefits, TANF state policy characteristics), and state fixed effects. The reference group for TANF policy is states that did not implement full work sanction and did not have a time limit shorter than 60 months. Standard errors are in parentheses. The results from Wald tests examining whether coefficients from interactions between YPI $\times$ treat $\times$ full sanction and YPI $\times$ treat $\times<60$ months are the same at the particular YPI category are presented in the YPI $\times$ treat $\times<60$ months rows (^indicates $0.1>p \geq 0.05$, and ${ }^{\wedge}{ }^{\wedge}$ indicates $p<0.05$ ). For example, if Wald tests reveal that the " $0-1$ year $\times$ treat $\times$ full sanction" coefficient is different from the " $0-1$ year $\times$ treat $\times<60$ months" coefficient, and the p-value is smaller than 0.05 , the " $0-1$ year $\times$ treat $\times<60$ month" row will be marked as $\wedge$. Model (1) includes the full sample, Model (2) further controls for year fixed effects and state-specific linear trends, and Model (3) restricts the sample to those living in states that did not implement a waiver policy on time limits or work sanctions prior to 1996

${ }^{+} \mathrm{p}<0.10 .{ }^{*} \mathrm{p}<0.05$. ${ }^{*} \mathrm{p}<0.01 . * * * \mathrm{p}<.001$

Table 3 presents the results for TANF participation. The first set of coefficients captures the interactions between categories of YPI and the treatment group status, depicting the associations between welfare reform and outcomes across time. The second and third sets of coefficients further test whether the associations in the first set differ for states that implemented full sanction policies or time limits that were shorter than 60 months. The results in Model (1) show that the TANF participation rates of single mothers post-reform were significantly lower than those of single mothers pre-reform relative to married mothers, dropping by $3.3 \%$ points in the initial 2 years after the reform to 11.2 to $20.2 \%$ points in $2-10$ years post-reform. Relative to their married counterparts, single mothers living in states with stringent policies experienced a sharper decrease in TANF participation than those living in states with standard policies. Both sanction and time limit policies were associated with lower TANF participation rates (by 3.8 to $6.9 \%$ points) even until 6-10 years after the reform. The reduction was more robust for time limit policies in Model (3), when states with waiver policies before 1996 were excluded from the analysis.

Table 4 presents the results on SNAP and SSI participation status. The results in Model (1) indicate that, compared to prior to welfare reform, the reform was associated with a decrease in SNAP participation by 3.6 to $9.9 \%$ points throughout 10 years after the reform, and short time limit policies were further associated with reduced SNAP participation rates by 5.4 to $14.3 \%$ points. Sanction policies were not associated with SNAP participation rates. In regard to SSI participation, the results show that the reform and TANF policy characteristics were largely not associated with the participation rates. One exception was that at 4-5 years after the reform, full work sanction policies were associated with a decline in SSI participation.

Table 5 presents the results from the analyses of labor supply, which is characterized by employment rates and work hours. After the welfare reform, employment rates increased by 3.7 to $6.0 \%$ points relative to the pre- reform era, and the employment increase was sustained throughout the 10 years of the post-reform period. However, policy stringencies were not associated with employment rates, indicating that a shorter time limit or full work sanction did not prompt single mothers to work more than married mothers. With respect to work hours, after using the Heckman selection model, accounting for the differential selection into employment, welfare reform was not associated with increases in work hours. Full sanctions were not associated with changes in work hours, but short time limit policies in general increased work hours, and such an increase was higher 4-7 years after the reform (when some families reached time limits) or in states that had waiver policies. Table 6 presents the results regarding income. The results do not suggest that the welfare reform or TANF 
Table 4 Trajectories of SNAP and SSI participation and policy stringencies

\begin{tabular}{|c|c|c|c|c|c|c|}
\hline & \multicolumn{3}{|c|}{ SNAP participation } & \multicolumn{3}{|c|}{ SSI participation } \\
\hline & $\begin{array}{l}\text { Full sample } \\
\text { (1) }\end{array}$ & $\begin{array}{l}\text { State-specific } \\
\text { trend } \\
\text { (2) }\end{array}$ & $\begin{array}{l}\text { States with no } \\
\text { waiver before } \\
1996 \text { (3) }\end{array}$ & $\begin{array}{l}\text { Full Sample } \\
\text { (1) }\end{array}$ & $\begin{array}{l}\text { State-specific } \\
\text { trend } \\
\text { (2) }\end{array}$ & $\begin{array}{l}\text { States with no } \\
\text { waiver before } \\
1996 \text { (3) }\end{array}$ \\
\hline \multicolumn{7}{|c|}{ Years since policy influence (YPI) (reference: -2 to -1 year) } \\
\hline $0-1$ year $\times$ treat & $\begin{array}{l}-0.036^{* *} \\
(0.011)\end{array}$ & $\begin{array}{l}-0.036^{* *} \\
(0.011)\end{array}$ & $\begin{array}{l}-0.029 * \\
(0.013)\end{array}$ & $\begin{array}{l}0.008 \\
(0.006)\end{array}$ & $\begin{array}{l}0.008 \\
(0.006)\end{array}$ & $\begin{array}{l}0.010 \\
(0.008)\end{array}$ \\
\hline $2-3$ year $\times$ treat & $\begin{array}{l}-0.099 * * * \\
(0.014)\end{array}$ & $\begin{array}{l}-0.099 * * * \\
(0.014)\end{array}$ & $\begin{array}{l}-0.093 * * * \\
(0.017)\end{array}$ & $\begin{array}{l}-0.000 \\
(0.008)\end{array}$ & $\begin{array}{l}0.000 \\
(0.008)\end{array}$ & $\begin{array}{l}-0.000 \\
(0.010)\end{array}$ \\
\hline $4-5$ year $\times$ treat & $\begin{array}{l}-0.099 * * * \\
(0.017)\end{array}$ & $\begin{array}{l}-0.099 * * * \\
(0.017)\end{array}$ & $\begin{array}{l}-0.079 * * * \\
(0.020)\end{array}$ & $\begin{array}{l}0.011 \\
(0.010)\end{array}$ & $\begin{array}{l}0.011 \\
(0.010)\end{array}$ & $\begin{array}{l}0.015 \\
(0.012)\end{array}$ \\
\hline $6-7$ year $\times$ treat & $\begin{array}{l}-0.097 * * * \\
(0.018)\end{array}$ & $\begin{array}{l}-0.098 * * * \\
(0.018)\end{array}$ & $\begin{array}{l}-0.070 * * * \\
(0.021)\end{array}$ & $\begin{array}{l}0.004 \\
(0.011)\end{array}$ & $\begin{array}{l}0.005 \\
(0.011)\end{array}$ & $\begin{array}{l}0.003 \\
(0.013)\end{array}$ \\
\hline $8-10$ year $\times$ treat & $\begin{array}{l}-0.081 * * * \\
(0.019)\end{array}$ & $\begin{array}{l}-0.082^{* * * *} \\
(0.019)\end{array}$ & $\begin{array}{l}-0.079 * * * \\
(0.023)\end{array}$ & $\begin{array}{l}0.023^{+} \\
(0.012)\end{array}$ & $\begin{array}{l}0.024^{*} \\
(0.012)\end{array}$ & $\begin{array}{l}0.030 * \\
(0.014)\end{array}$ \\
\hline \multicolumn{7}{|l|}{ YPI $\times$ sanction } \\
\hline $0-1$ year $\times$ treat $\times$ full sanction & $\begin{array}{l}-0.013 \\
(0.021)\end{array}$ & $\begin{array}{l}-0.014 \\
(0.021)\end{array}$ & $\begin{array}{l}-0.006 \\
(0.030)\end{array}$ & $\begin{array}{l}-0.013 \\
(0.012)\end{array}$ & $\begin{array}{l}-0.013 \\
(0.012)\end{array}$ & $\begin{array}{l}-0.018 \\
(0.018)\end{array}$ \\
\hline $2-3$ year $\times$ treat $\times$ full sanction & $\begin{array}{l}-0.019 \\
(0.023)\end{array}$ & $\begin{array}{l}-0.022 \\
(0.023)\end{array}$ & $\begin{array}{l}-0.022 \\
(0.034)\end{array}$ & $\begin{array}{l}-0.019 \\
(0.013)\end{array}$ & $\begin{array}{l}-0.020 \\
(0.013)\end{array}$ & $\begin{array}{l}-0.008 \\
(0.020)\end{array}$ \\
\hline $4-5$ year $\times$ treat $\times$ full sanction & $\begin{array}{l}0.040 \\
(0.033)\end{array}$ & $\begin{array}{l}0.036 \\
(0.033)\end{array}$ & $\begin{array}{l}-0.011 \\
(0.051)\end{array}$ & $\begin{array}{l}-0.043^{*} \\
(0.021)\end{array}$ & $\begin{array}{l}-0.043^{*} \\
(0.021)\end{array}$ & $\begin{array}{l}-0.062^{+} \\
(0.034)\end{array}$ \\
\hline $6-7$ year $\times$ treat $\times$ full sanction & $\begin{array}{l}0.006 \\
(0.032)\end{array}$ & $\begin{array}{l}-0.000 \\
(0.032)\end{array}$ & $\begin{array}{l}-0.039 \\
(0.048)\end{array}$ & $\begin{array}{l}-0.012 \\
(0.020)\end{array}$ & $\begin{array}{l}-0.013 \\
(0.020)\end{array}$ & $\begin{array}{l}-0.009 \\
(0.032)\end{array}$ \\
\hline $8-10$ year $\times$ treat $\times$ full sanction & $\begin{array}{l}0.006 \\
(0.034)\end{array}$ & $\begin{array}{l}0.001 \\
(0.034)\end{array}$ & $\begin{array}{l}-0.032 \\
(0.050)\end{array}$ & $\begin{array}{l}-0.024 \\
(0.022)\end{array}$ & $\begin{array}{l}-0.024 \\
(0.022)\end{array}$ & $\begin{array}{l}-0.040 \\
(0.034)\end{array}$ \\
\hline \multicolumn{7}{|l|}{ YPI $\times$ time limit } \\
\hline $0-1$ year $\times$ treat $\times<60$ month & $\begin{array}{l}-0.054^{+} \\
(0.028)\end{array}$ & $\begin{array}{l}-0.055^{*} \\
(0.028)\end{array}$ & $\begin{array}{l}-0.082 * \\
(0.040)\end{array}$ & $\begin{array}{l}-0.014 \\
(0.016)\end{array}$ & $\begin{array}{l}-0.013 \\
(0.016)\end{array}$ & $\begin{array}{l}-0.001 \\
(0.023)\end{array}$ \\
\hline $2-3$ year $\times$ treat $\times<60$ month & $\begin{array}{l}-0.109 * * * \wedge \wedge \\
(0.031)\end{array}$ & $\begin{array}{l}-0.109 * * * \wedge \wedge \\
(0.031)\end{array}$ & $\begin{array}{l}-0.147^{* * \wedge} \\
(0.045)\end{array}$ & $\begin{array}{l}-0.024 \\
(0.018)\end{array}$ & $\begin{array}{l}-0.024 \\
(0.018)\end{array}$ & $\begin{array}{l}-0.022 \\
(0.027)\end{array}$ \\
\hline $4-5$ year $\times$ treat $\times<60$ month & $\begin{array}{l}-0.091^{* \wedge \wedge} \\
(0.043)\end{array}$ & $\begin{array}{l}-0.087^{* \wedge \wedge} \\
(0.043)\end{array}$ & $\begin{array}{l}-0.104 \\
(0.064)\end{array}$ & $\begin{array}{l}-0.023 \\
(0.026)\end{array}$ & $\begin{array}{l}-0.021 \\
(0.027)\end{array}$ & $\begin{array}{l}0.002 \\
(0.042)\end{array}$ \\
\hline $6-7$ year $\times$ treat $x<60$ month & $\begin{array}{l}-0.113^{* * \wedge \wedge} \\
(0.042)\end{array}$ & $\begin{array}{l}-0.104^{* \wedge} \\
(0.042)\end{array}$ & $\begin{array}{l}-0.108^{+} \\
(0.062)\end{array}$ & $\begin{array}{l}-0.038 \\
(0.027)\end{array}$ & $\begin{array}{l}-0.034 \\
(0.027)\end{array}$ & $\begin{array}{l}-0.027 \\
(0.041)\end{array}$ \\
\hline $8-10$ year $\times$ treat $\times<60$ month & $\begin{array}{l}-0.143^{* * \wedge \wedge} \\
(0.047)\end{array}$ & $\begin{array}{l}-0.133^{* * \wedge \wedge} \\
(0.047)\end{array}$ & $\begin{array}{l}-0.113^{+} \\
(0.067)\end{array}$ & $\begin{array}{l}-0.015 \\
(0.029)\end{array}$ & $\begin{array}{l}-0.012 \\
(0.030)\end{array}$ & $\begin{array}{l}-0.002 \\
(0.044)\end{array}$ \\
\hline Treat & $\begin{array}{l}0.208^{+} \\
(0.125)\end{array}$ & $\begin{array}{l}0.206^{+} \\
(0.125)\end{array}$ & $\begin{array}{l}0.252^{+} \\
(0.145)\end{array}$ & $\begin{array}{l}0.046 \\
(0.087)\end{array}$ & $\begin{array}{l}0.039 \\
(0.087)\end{array}$ & $\begin{array}{l}-0.034 \\
(0.102)\end{array}$ \\
\hline Treat $\times$ full sanction & $\begin{array}{l}0.007 \\
(0.027)\end{array}$ & $\begin{array}{l}0.011 \\
(0.027)\end{array}$ & $\begin{array}{l}0.006 \\
(0.039)\end{array}$ & $\begin{array}{l}0.032^{+} \\
(0.018)\end{array}$ & $\begin{array}{l}0.032^{+} \\
(0.018)\end{array}$ & $\begin{array}{l}0.043 \\
(0.027)\end{array}$ \\
\hline Treat $\times<60$ month & $\begin{array}{l}0.072 * \\
(0.035)\end{array}$ & $\begin{array}{l}0.069 * \\
(0.035)\end{array}$ & $\begin{array}{l}0.076 \\
(0.051)\end{array}$ & $\begin{array}{l}0.045^{*} \\
(0.023)\end{array}$ & $\begin{array}{l}0.043^{+} \\
(0.023)\end{array}$ & $\begin{array}{l}0.047 \\
(0.034)\end{array}$ \\
\hline Constant & $\begin{array}{l}0.851 * * \\
(0.294)\end{array}$ & $\begin{array}{l}0.712 * \\
(0.349)\end{array}$ & $\begin{array}{l}0.785^{*} \\
(0.321)\end{array}$ & $\begin{array}{l}0.032 \\
(0.177)\end{array}$ & $\begin{array}{l}-0.105 \\
(0.204)\end{array}$ & $\begin{array}{l}0.219 \\
(0.197)\end{array}$ \\
\hline \multicolumn{7}{|l|}{ Variance terms } \\
\hline State intercepts & 0.000 & 0.000 & 0.000 & 0.000 & 0.000 & 0.000 \\
\hline Ind. intercepts & 0.083 & 0.083 & 0.087 & 0.048 & 0.048 & 0.049 \\
\hline Residuals & 0.050 & 0.050 & 0.050 & 0.016 & 0.016 & 0.017 \\
\hline
\end{tabular}


Table 4 (continued)

\begin{tabular}{|c|c|c|c|c|c|c|}
\hline & \multicolumn{3}{|c|}{ SNAP participation } & \multicolumn{3}{|c|}{ SSI participation } \\
\hline & $\begin{array}{l}\text { Full sample } \\
\text { (1) }\end{array}$ & $\begin{array}{l}\text { State-specific } \\
\text { trend } \\
(2)\end{array}$ & $\begin{array}{l}\text { States with no } \\
\text { waiver before } \\
1996 \text { (3) }\end{array}$ & $\begin{array}{l}\text { Full Sample } \\
\text { (1) }\end{array}$ & $\begin{array}{l}\text { State-specific } \\
\text { trend } \\
(2)\end{array}$ & $\begin{array}{l}\text { States with no } \\
\text { waiver before } \\
1996 \text { (3) }\end{array}$ \\
\hline $\mathrm{N}$ & 38,146 & 38,146 & 25,111 & 38,146 & 38,146 & 25,111 \\
\hline
\end{tabular}

Each column is a separate linear multilevel regression model. See Table 3 for sample and model specifications. Standard errors are in parentheses ${ }^{+} \mathrm{p}<0.10 . * \mathrm{p}<0.05 . * * \mathrm{p}<0.01 . * * * \mathrm{p}<.001$

policy characteristics were strongly associated with earned income or family income. ${ }^{32}$ This finding indicates that although welfare reform increased employment among single mothers relative to married mothers, this increase did not bring additional financial resources into the family. In addition, while shorter time limits were associated with increased work hours 4-7 years after the reform, this increase in work hours also did not bring in additional financial gain.

Table 7 presents results from the examination of whether welfare reform or stringent TANF policies were related to the likelihood of being financially independent (not receiving financial assistance from welfare programs [TANF, SNAP, or SSI], relatives, or friends; this measure does not factor in respondents' earnings). The results reveal that welfare reform was associated with increases of 4.4 to $11.2 \%$ points in not receiving assistance from welfare programs, relatives, or friends. In regard to the associations between policy stringencies and financial independence trajectories, short time limits were associated with further increases of 7.7 to $13.2 \%$ points in being financially independent between 2 and 10 years after the welfare reform.

In Tables 8 and 9, I examine the extent to which the main findings described above vary by race. I only conducted the analyses for White and Black single mothers due to the relatively small sample sizes for single mothers of other races. Most of the findings were consistent across races, with two exceptions. First, with regard to welfare participation, although Black and White single mothers all experienced declines in TANF participation, sanction policies significantly reduced TANF participation at higher rates among White single mothers than among Black single mothers. Second, with respect to employment, the employment rates among Black single mothers increased

\footnotetext{
32 From the findings of sensitivity analyses (Appendix Table 16), there is some evidence that short time limit policies were associated with increases in earned income 4-7 years after the TANF implementation, but the statistical significance was not consistent across models.
}

four years after TANF's implementation, yet the employment rates were lower for Black single mothers living in states with stringent sanction policies.

\section{Sensitivity Analyses}

In addition to controlling for state-specific trends and restricting the analyses to states without a waiver policy before 1996, I administered four additional sensitivity analyses, and the results are presented in Appendix 2 Tables. In Model (3), the samples are restricted to the mother having arrived in the state of residence before 1992, before any state started to implement AFDC waiver policies (assuming that no one could foresee state TANF policy choices before 1992). In Model (4), the samples are restricted to respondents who responded to all years of survey in the SIPP to check whether the results are sensitive to attrition from these short panels. In Model (5), the samples are restricted to states that did not change time limit or sanction policies during the study period. In Model (6), I included additional controls of SNAP policy characteristics $^{33}$ and treatment status' interactions with these characteristics. As SNAP has become the largest near-cash

\footnotetext{
33 Specifically, I control for the following time-variant SNAP policy characteristics and their interactions with treatment status: [1] whether the state requires fingerprinting of SNAP applicants; [2] the sum of federal, state, and grant outreach spending in nominal dollars (\$1000s); [3] regarding households with earnings, whether the state uses the simplified reporting option that reduces requirements for reporting changes in household circumstances; [4] whether the state exempts an amount higher than the SNAP standard auto exemption (set at $\$ 4,650$ in FY2013) from the fair market value to determine the countable resource value of a vehicle; [5] whether the state disqualifies SNAP applicants or recipients who fail to perform actions required by other means-tested programs, primarily TANF; [6] the proportion of SNAP units with earnings with $13^{+}$month recertification periods; [7] whether the state operates a combined application project for recipients of SSI, such that SSI recipients are able to use a streamlined SNAP application process; and [8] whether the state uses broad-based categorical eligibility to increase or eliminate the asset test and/or to increase the gross income limit for virtually all SNAP applicants (Economic Research Service [ERS], USDA 2017).
} 
Table 5 Trajectories of labor supply and policy stringencies

\begin{tabular}{|c|c|c|c|c|c|c|}
\hline & \multicolumn{3}{|l|}{ Employment } & \multicolumn{3}{|c|}{ Average monthly work hours } \\
\hline & $\begin{array}{l}\text { Full sample } \\
\text { (1) }\end{array}$ & $\begin{array}{l}\text { State-specific } \\
\text { trend } \\
\text { (2) }\end{array}$ & $\begin{array}{l}\text { States with no } \\
\text { waiver before } \\
1996 \text { (3) }\end{array}$ & $\begin{array}{l}\text { Full sample } \\
\text { (1) }\end{array}$ & $\begin{array}{l}\text { State-specific } \\
\text { trend } \\
(2)\end{array}$ & $\begin{array}{l}\text { States with no } \\
\text { waiver before } \\
1996 \text { (3) }\end{array}$ \\
\hline \multicolumn{7}{|c|}{ Years since policy influence (YPI) (reference: -2 to -1 year) } \\
\hline $0-1$ year $\times$ treat & $\begin{array}{l}0.037 * \\
(0.014)\end{array}$ & $\begin{array}{l}0.036 * \\
(0.014)\end{array}$ & $\begin{array}{l}0.026 \\
(0.017)\end{array}$ & $\begin{array}{l}-3.084 \\
(3.293)\end{array}$ & $\begin{array}{l}-3.219 \\
(3.291)\end{array}$ & $\begin{array}{l}-3.261 \\
(3.942)\end{array}$ \\
\hline $2-3$ year $\times$ treat & $\begin{array}{l}0.041^{*} \\
(0.018)\end{array}$ & $\begin{array}{l}0.041 * \\
(0.018)\end{array}$ & $\begin{array}{l}0.029 \\
(0.021)\end{array}$ & $\begin{array}{l}-5.013 \\
(4.066)\end{array}$ & $\begin{array}{l}-5.290 \\
(4.052)\end{array}$ & $\begin{array}{l}-4.436 \\
(4.767)\end{array}$ \\
\hline $4-5$ year $\times$ treat & $\begin{array}{l}0.060 * * \\
(0.021)\end{array}$ & $\begin{array}{l}0.058 * * \\
(0.021)\end{array}$ & $\begin{array}{l}0.054 * \\
(0.025)\end{array}$ & $\begin{array}{l}-7.576^{+} \\
(4.301)\end{array}$ & $\begin{array}{l}-7.926^{+} \\
(4.281)\end{array}$ & $\begin{array}{l}-6.903 \\
(4.996)\end{array}$ \\
\hline $6-7$ year $\times$ treat & $\begin{array}{l}0.040^{+} \\
(0.022)\end{array}$ & $\begin{array}{l}0.038^{+} \\
(0.022)\end{array}$ & $\begin{array}{l}0.030 \\
(0.026)\end{array}$ & $\begin{array}{l}-4.706 \\
(4.197)\end{array}$ & $\begin{array}{l}-5.001 \\
(4.181)\end{array}$ & $\begin{array}{l}-3.982 \\
(4.872)\end{array}$ \\
\hline $8-10$ year $\times$ treat & $\begin{array}{l}0.048 * \\
(0.024)\end{array}$ & $\begin{array}{l}0.047^{+} \\
(0.024)\end{array}$ & $\begin{array}{l}0.042 \\
(0.028)\end{array}$ & $\begin{array}{l}-7.654^{+} \\
(4.434)\end{array}$ & $\begin{array}{l}-7.615^{+} \\
(4.430)\end{array}$ & $\begin{array}{l}-5.548 \\
(5.243)\end{array}$ \\
\hline \multicolumn{7}{|l|}{ YPI $\times$ sanction } \\
\hline $0-1$ year $\times$ treat $\times$ full sanction & $\begin{array}{l}0.029 \\
(0.026)\end{array}$ & $\begin{array}{l}0.028 \\
(0.026)\end{array}$ & $\begin{array}{l}0.040 \\
(0.037)\end{array}$ & $\begin{array}{l}2.142 \\
(5.872)\end{array}$ & $\begin{array}{l}2.023 \\
(5.874)\end{array}$ & $\begin{array}{l}2.484 \\
(7.679)\end{array}$ \\
\hline $2-3$ year $\times$ treat $\times$ full sanction & $\begin{array}{l}0.015 \\
(0.028)\end{array}$ & $\begin{array}{l}0.012 \\
(0.029)\end{array}$ & $\begin{array}{l}0.031 \\
(0.043)\end{array}$ & $\begin{array}{l}1.208 \\
(6.662)\end{array}$ & $\begin{array}{l}1.086 \\
(6.688)\end{array}$ & $\begin{array}{l}12.472 \\
(9.457)\end{array}$ \\
\hline $4-5$ year $\times$ treat $\times$ full sanction & $\begin{array}{l}-0.029 \\
(0.041)\end{array}$ & $\begin{array}{l}-0.032 \\
(0.041)\end{array}$ & $\begin{array}{l}-0.018 \\
(0.063)\end{array}$ & $\begin{array}{l}-3.565 \\
(8.004)\end{array}$ & $\begin{array}{l}-3.536 \\
(8.015)\end{array}$ & $\begin{array}{l}7.104 \\
(10.560)\end{array}$ \\
\hline $6-7$ year $\times$ treat $\times$ full sanction & $\begin{array}{l}0.016 \\
(0.039)\end{array}$ & $\begin{array}{l}0.012 \\
(0.039)\end{array}$ & $\begin{array}{l}0.028 \\
(0.059)\end{array}$ & $\begin{array}{l}-3.180 \\
(7.245)\end{array}$ & $\begin{array}{l}-2.761 \\
(7.276)\end{array}$ & $\begin{array}{l}6.263 \\
(9.035)\end{array}$ \\
\hline $8-10$ year $\times$ treat $\times$ full sanction & $\begin{array}{l}-0.003 \\
(0.042)\end{array}$ & $\begin{array}{l}-0.009 \\
(0.042)\end{array}$ & $\begin{array}{l}0.018 \\
(0.061)\end{array}$ & $\begin{array}{l}1.084 \\
(7.586)\end{array}$ & $\begin{array}{l}1.141 \\
(7.632)\end{array}$ & $\begin{array}{l}7.344 \\
(9.368)\end{array}$ \\
\hline \multicolumn{7}{|l|}{ YPI $\times$ time limit } \\
\hline $0-1$ year $\times$ treat $\times<60$ month & $\begin{array}{l}-0.004 \\
(0.035)\end{array}$ & $\begin{array}{l}-0.005 \\
(0.035)\end{array}$ & $\begin{array}{l}0.007 \\
(0.049)\end{array}$ & $\begin{array}{l}10.976 \\
(6.979)\end{array}$ & $\begin{array}{l}11.185 \\
(6.997)\end{array}$ & $\begin{array}{l}5.097 \\
(9.087)\end{array}$ \\
\hline $2-3$ year $\times$ treat $\times<60$ month & $\begin{array}{l}0.040 \\
(0.038)\end{array}$ & $\begin{array}{l}0.039 \\
(0.039)\end{array}$ & $\begin{array}{l}-0.008 \\
(0.057)\end{array}$ & $\begin{array}{l}13.143 \\
(8.675)\end{array}$ & $\begin{array}{l}13.735 \\
(8.725)\end{array}$ & $\begin{array}{l}0.233 \\
(11.342)\end{array}$ \\
\hline $4-5$ year $\times$ treat $x<60$ month & $\begin{array}{l}0.043 \\
(0.053)\end{array}$ & $\begin{array}{l}0.040 \\
(0.053)\end{array}$ & $\begin{array}{l}0.081 \\
(0.080)\end{array}$ & $\begin{array}{l}20.824 * \wedge \\
(9.437)\end{array}$ & $\begin{array}{l}22.377 * \wedge \wedge \\
(9.445)\end{array}$ & $\begin{array}{l}13.080 \\
(12.991)\end{array}$ \\
\hline $6-7$ year $\times$ treat $\times<60$ month & $\begin{array}{l}-0.041 \\
(0.052)\end{array}$ & $\begin{array}{l}-0.042 \\
(0.053)\end{array}$ & $\begin{array}{l}0.029 \\
(0.077)\end{array}$ & $\begin{array}{l}25.415^{* * \wedge \wedge} \\
(8.645)\end{array}$ & $\begin{array}{l}26.337^{* * \wedge \wedge} \\
(8.663)\end{array}$ & $\begin{array}{l}15.502 \\
(11.598)\end{array}$ \\
\hline $8-10$ year $\times$ treat $\times<60$ month & $\begin{array}{l}-0.032 \\
(0.058)\end{array}$ & $\begin{array}{l}-0.037 \\
(0.058)\end{array}$ & $\begin{array}{l}0.016 \\
(0.083)\end{array}$ & $\begin{array}{l}15.947^{+} \\
(9.566)\end{array}$ & $\begin{array}{l}16.856^{+} \\
(9.626)\end{array}$ & $\begin{array}{l}9.684 \\
(12.998)\end{array}$ \\
\hline Treat & $\begin{array}{l}-0.101 \\
(0.153)\end{array}$ & $\begin{array}{l}-0.098 \\
(0.153)\end{array}$ & $\begin{array}{l}0.026 \\
(0.178)\end{array}$ & $\begin{array}{l}-44.623 * \\
(22.377)\end{array}$ & $\begin{array}{l}-42.772^{+} \\
(22.261)\end{array}$ & $\begin{array}{l}-63.917 * \\
(25.791)\end{array}$ \\
\hline Treat $\times$ full sanction & $\begin{array}{l}-0.044 \\
(0.033)\end{array}$ & $\begin{array}{l}-0.039 \\
(0.033)\end{array}$ & $\begin{array}{l}-0.054 \\
(0.048)\end{array}$ & $\begin{array}{l}-0.897 \\
(6.340)\end{array}$ & $\begin{array}{l}-1.216 \\
(6.368)\end{array}$ & $\begin{array}{l}-6.408 \\
(7.615)\end{array}$ \\
\hline Treat $\times<60$ month & $\begin{array}{l}0.018 \\
(0.043)\end{array}$ & $\begin{array}{l}0.017 \\
(0.043)\end{array}$ & $\begin{array}{l}-0.035 \\
(0.063)\end{array}$ & $\begin{array}{l}-17.699 * \\
(7.312)\end{array}$ & $\begin{array}{l}-18.525^{*} \\
(7.329)\end{array}$ & $\begin{array}{l}-9.878 \\
(9.901)\end{array}$ \\
\hline Constant & $\begin{array}{l}0.932 * \\
(0.365)\end{array}$ & $\begin{array}{l}1.061 * \\
(0.435)\end{array}$ & $\begin{array}{l}0.976^{*} \\
(0.398)\end{array}$ & $\begin{array}{l}83.429 \\
(65.579)\end{array}$ & $\begin{array}{l}174.541 * \\
(85.613)\end{array}$ & $\begin{array}{l}110.314 \\
(77.538)\end{array}$ \\
\hline \multicolumn{7}{|l|}{ Variance terms } \\
\hline State intercepts & 0.000 & 0.000 & 0.000 & - & - & - \\
\hline Ind. intercepts & 0.124 & 0.124 & 0.129 & - & - & - \\
\hline Residuals & 0.079 & 0.079 & 0.079 & - & - & - \\
\hline
\end{tabular}


Table 5 (continued)

\begin{tabular}{|c|c|c|c|c|c|c|}
\hline & \multicolumn{3}{|l|}{ Employment } & \multicolumn{3}{|c|}{ Average monthly work hours } \\
\hline & $\begin{array}{l}\text { Full sample } \\
\text { (1) }\end{array}$ & $\begin{array}{l}\text { State-specific } \\
\text { trend } \\
(2)\end{array}$ & $\begin{array}{l}\text { States with no } \\
\text { waiver before } \\
1996 \text { (3) }\end{array}$ & $\begin{array}{l}\text { Full sample } \\
\text { (1) }\end{array}$ & $\begin{array}{l}\text { State-specific } \\
\text { trend } \\
(2)\end{array}$ & $\begin{array}{l}\text { States with no } \\
\text { waiver before } \\
1996(3)\end{array}$ \\
\hline $\mathrm{N}$ & 38,146 & 38,146 & 25,111 & 38,146 & 38,146 & 25,111 \\
\hline
\end{tabular}

Each column is a separate linear multilevel regression model. For the outcome "Work Hours", I adopt the Heckman selection model. See Table 3 for sample and model specifications. Standard errors are in parentheses

${ }^{+} \mathrm{p}<0.10 . * \mathrm{p}<0.05 . * * \mathrm{p}<0.01 . * * * \mathrm{p}<.001$

safety net in the United States, checking whether findings are sensitive to SNAP policy rules is important, particularly for understanding the findings on the SNAP participation outcome. Overall, the results from these sensitivity analyses were qualitatively similar to the main findings presented in this paper.

\section{Discussion}

This study examines long-term welfare use, labor supply, and income trajectories since the 1996 welfare reform and the conditions under which these trajectories differ by state TANF policy stringencies. I adopt a DDD design and use low-educated single mothers at the time of the policy implementation as the treatment group and their married counterparts as the comparison group. First, with respect to findings on welfare reform, overall, welfare reform was strongly associated with decreases in single mothers' TANF and SNAP participation and increases in employment relative to married mothers throughout the 10 years following the reform. Despite the increase in employment post-reform, the reform did not increase work hours, and the growth in the earnings or family income of women in the treatment groups was not different from the increases shown among women in the comparison group. In addition, welfare reform was associated with a higher likelihood of being financially independent (not receiving support from welfare programs or relatives or friends) throughout the period.

Second, when examining the impacts of stringencies of state TANF sanction and time limit policies, this study found that more stringent TANF policies were associated with lower TANF participation rates among single mothers throughout the 10 years after the state TANF policy implementation. In terms of program participation status in other welfare programs, short time limit policies were associated with reduced SNAP participation rates but not SSI participation rates, and work sanctions were not associated with changes in SNAP and SSI participation rates. In regard to labor supply, TANF policy stringencies were not associated with levels of employment, but short time limits increased work hours 4-7 years after the TANF implementation, a period when some families reached their time limit. With respect to income, TANF policy stringencies were not related to levels of monthly earnings or family income among single mothers. Finally, short time limit policies were associated with increased financial independence.

Associations between welfare reform and lower TANF use found in this study were consistent with the declining trends in welfare caseloads post-PRWORA (ACF 2018). This study further reveals that, compared with less stringent policies, more stringent policies were associated with reduced caseloads to a greater extent, by 4 to $8 \%$ points, until at least 10 years after the reform. These declines are considerably large given that the original gap between stringent and not stringent states in AFDC participation rates one year to 2 years before TANF implementation was only $2 \%$ point. In addition, the associations between short time limit policies and reduced welfare caseloads spill over to the SNAP program, and this relationship holds even after accounting for various state policy characteristics (e.g., other TANF welfare rules, state EITC, and a wide range of state SNAP policy rules). 
Table 6 Trajectories of income and policy stringencies

\begin{tabular}{|c|c|c|c|c|c|c|}
\hline & \multicolumn{3}{|c|}{ Log (monthly earnings) } & \multicolumn{3}{|c|}{ Log (monthly family income) } \\
\hline & $\begin{array}{l}\text { Full sample } \\
\text { (1) }\end{array}$ & $\begin{array}{l}\text { State-specific } \\
\text { trend } \\
(2)\end{array}$ & $\begin{array}{l}\text { States with no } \\
\text { waiver before } \\
1996 \text { (3) }\end{array}$ & $\begin{array}{l}\text { Full sample } \\
\text { (1) }\end{array}$ & $\begin{array}{l}\text { State-specific } \\
\text { trend } \\
\text { (2) }\end{array}$ & $\begin{array}{l}\text { States with no } \\
\text { waiver before } \\
1996 \text { (3) }\end{array}$ \\
\hline \multicolumn{7}{|c|}{ Years since policy influence (YPI) (reference: -2 to -1 year) } \\
\hline $0-1$ year $\times$ treat & $\begin{array}{l}0.009 \\
(0.049)\end{array}$ & $\begin{array}{c}\text { This model did } \\
\text { not converge }\end{array}$ & $\begin{array}{l}-0.063 \\
(0.068)\end{array}$ & $\begin{array}{l}0.005 \\
(0.031)\end{array}$ & $\begin{array}{l}0.004 \\
(0.031)\end{array}$ & $\begin{array}{l}-0.030 \\
(0.035)\end{array}$ \\
\hline $2-3$ year $\times$ treat & $\begin{array}{l}-0.003 \\
(0.060)\end{array}$ & & $\begin{array}{l}-0.074 \\
(0.082)\end{array}$ & $\begin{array}{l}-0.037 \\
(0.038)\end{array}$ & $\begin{array}{l}-0.034 \\
(0.038)\end{array}$ & $\begin{array}{l}-0.081 \mathrm{v} \\
(0.044)\end{array}$ \\
\hline $4-5$ year $\times$ treat & $\begin{array}{l}-0.013 \\
(0.067)\end{array}$ & & $\begin{array}{l}-0.096 \\
(0.089)\end{array}$ & $\begin{array}{l}0.062 \\
(0.044)\end{array}$ & $\begin{array}{l}0.062 \\
(0.044)\end{array}$ & $\begin{array}{l}0.080 \\
(0.050)\end{array}$ \\
\hline $6-7$ year $\times$ treat & $\begin{array}{l}-0.018 \\
(0.065)\end{array}$ & & $\begin{array}{l}-0.040 \\
(0.087)\end{array}$ & $\begin{array}{l}0.030 \\
(0.046)\end{array}$ & $\begin{array}{l}0.031 \\
(0.046)\end{array}$ & $\begin{array}{l}0.033 \\
(0.052)\end{array}$ \\
\hline $8-10$ year $\times$ treat & $\begin{array}{l}-0.081 \\
(0.070)\end{array}$ & & $\begin{array}{l}-0.112 \\
(0.096)\end{array}$ & $\begin{array}{l}-0.028 \\
(0.049)\end{array}$ & $\begin{array}{l}-0.021 \\
(0.049)\end{array}$ & $\begin{array}{l}-0.024 \\
(0.057)\end{array}$ \\
\hline \multicolumn{7}{|l|}{ YPI $\times$ sanction } \\
\hline $0-1$ year $\times$ treat $\times$ full sanction & $\begin{array}{l}0.072 \\
(0.086)\end{array}$ & & $\begin{array}{l}-0.006 \\
(0.140)\end{array}$ & $\begin{array}{l}-0.002 \\
(0.055)\end{array}$ & $\begin{array}{l}0.001 \\
(0.055)\end{array}$ & $\begin{array}{l}0.106 \\
(0.080)\end{array}$ \\
\hline $2-3$ year $\times$ treat $\times$ full sanction & $\begin{array}{l}0.043 \\
(0.100)\end{array}$ & & $\begin{array}{l}0.034 \\
(0.170)\end{array}$ & $\begin{array}{l}0.015 \\
(0.061)\end{array}$ & $\begin{array}{l}0.021 \\
(0.061)\end{array}$ & $\begin{array}{l}0.139 \\
(0.091)\end{array}$ \\
\hline $4-5$ year $\times$ treat $\times$ full sanction & $\begin{array}{l}-0.038 \\
(0.121)\end{array}$ & & $\begin{array}{l}0.013 \\
(0.193)\end{array}$ & $\begin{array}{l}0.106 \\
(0.084)\end{array}$ & $\begin{array}{l}0.121 \\
(0.084)\end{array}$ & $\begin{array}{l}0.135 \\
(0.126)\end{array}$ \\
\hline $6-7$ year $\times$ treat $\times$ full sanction & $\begin{array}{l}-0.023 \\
(0.113)\end{array}$ & & $\begin{array}{l}-0.049 \\
(0.173)\end{array}$ & $\begin{array}{l}0.054 \\
(0.079)\end{array}$ & $\begin{array}{l}0.069 \\
(0.080)\end{array}$ & $\begin{array}{l}0.079 \\
(0.117)\end{array}$ \\
\hline $8-10$ year $\times$ treat $\times$ full sanction & $\begin{array}{l}0.012 \\
(0.119)\end{array}$ & & $\begin{array}{l}-0.007 \\
(0.182)\end{array}$ & $\begin{array}{l}0.110 \\
(0.085)\end{array}$ & $\begin{array}{l}0.123 \\
(0.086)\end{array}$ & $\begin{array}{l}0.170 \\
(0.121)\end{array}$ \\
\hline \multicolumn{7}{|l|}{ YPI $\times$ time limit } \\
\hline $0-1$ year $\times$ treat $\times<60$ month & $\begin{array}{l}-0.055 \\
(0.098)\end{array}$ & & $\begin{array}{l}-0.035 \\
(0.173)\end{array}$ & $\begin{array}{l}-0.129^{+} \\
(0.075)\end{array}$ & $\begin{array}{l}-0.124^{+} \\
(0.075)\end{array}$ & $\begin{array}{l}-0.219 * \wedge \wedge \\
(0.105)\end{array}$ \\
\hline 2-3 year $x$ treat $x<60$ month & $\begin{array}{l}0.082 \\
(0.112)\end{array}$ & & $\begin{array}{l}0.136 \\
(0.211)\end{array}$ & $\begin{array}{l}0.029 \\
(0.083)\end{array}$ & $\begin{array}{l}0.038 \\
(0.083)\end{array}$ & $\begin{array}{l}0.121 \\
(0.120)\end{array}$ \\
\hline $4-5$ year $\times$ treat $\times<60$ month & $\begin{array}{l}0.201 \\
(0.148)\end{array}$ & & $\begin{array}{l}0.096 \\
(0.235)\end{array}$ & $\begin{array}{l}0.026 \\
(0.109)\end{array}$ & $\begin{array}{l}0.039 \\
(0.110)\end{array}$ & $\begin{array}{l}0.086 \\
(0.159)\end{array}$ \\
\hline $6-7$ year $\times$ treat $x<60$ month & $\begin{array}{l}0.259^{+} \\
(0.132)\end{array}$ & & $\begin{array}{l}0.268 \\
(0.217)\end{array}$ & $\begin{array}{l}-0.183^{+\wedge} \\
(0.106)\end{array}$ & $\begin{array}{l}-0.167^{\wedge} \\
(0.107)\end{array}$ & $\begin{array}{l}-0.124 \\
(0.152)\end{array}$ \\
\hline $8-10$ year $\times$ treat $\times<60$ month & $\begin{array}{l}0.123 \\
(0.149)\end{array}$ & & $\begin{array}{l}0.186 \\
(0.237)\end{array}$ & $\begin{array}{l}-0.086 \\
(0.117)\end{array}$ & $\begin{array}{l}-0.066 \\
(0.118)\end{array}$ & $\begin{array}{l}-0.141 \\
(0.164)\end{array}$ \\
\hline Treat & $\begin{array}{l}-0.125 \\
(0.359)\end{array}$ & & $\begin{array}{l}-0.409 \\
(0.471)\end{array}$ & $\begin{array}{l}-0.471 \\
(0.299)\end{array}$ & $\begin{array}{l}-0.456 \\
(0.299)\end{array}$ & $\begin{array}{l}-0.537 \\
(0.342)\end{array}$ \\
\hline Treat $\times$ full sanction & $\begin{array}{l}-0.025 \\
(0.095)\end{array}$ & & $\begin{array}{l}0.043 \\
(0.140)\end{array}$ & $\begin{array}{l}-0.084 \\
(0.066)\end{array}$ & $\begin{array}{l}-0.100 \\
(0.066)\end{array}$ & $\begin{array}{l}-0.158^{+} \\
(0.095)\end{array}$ \\
\hline Treat $\times<60$ month & $\begin{array}{l}-0.144 \\
(0.107)\end{array}$ & & $\begin{array}{l}-0.061 \\
(0.174)\end{array}$ & $\begin{array}{l}0.052 \\
(0.086)\end{array}$ & $\begin{array}{l}0.042 \\
(0.086)\end{array}$ & $\begin{array}{l}0.113 \\
(0.123)\end{array}$ \\
\hline Constant & $\begin{array}{l}4.330 * * * \\
(1.057)\end{array}$ & & $\begin{array}{l}6.836 * * * \\
(1.432)\end{array}$ & $\begin{array}{l}8.219 * * * \\
(0.755)\end{array}$ & $\begin{array}{l}8.412 * * * \\
(0.917)\end{array}$ & $\begin{array}{l}8.061 * * * \\
(0.817)\end{array}$ \\
\hline
\end{tabular}


Table 6 continued

\begin{tabular}{|c|c|c|c|c|c|c|}
\hline & \multicolumn{3}{|c|}{ Log (monthly earnings) } & \multicolumn{3}{|c|}{ Log (monthly family income) } \\
\hline & $\begin{array}{l}\text { Full sample } \\
\text { (1) }\end{array}$ & $\begin{array}{l}\text { State-specific } \\
\text { trend } \\
(2)\end{array}$ & $\begin{array}{l}\text { States with no } \\
\text { waiver before } \\
1996 \text { (3) }\end{array}$ & $\begin{array}{l}\text { Full sample } \\
\text { (1) }\end{array}$ & $\begin{array}{l}\text { State-specific } \\
\text { trend } \\
(2)\end{array}$ & $\begin{array}{l}\text { States with no } \\
\text { waiver before } \\
1996 \text { (3) }\end{array}$ \\
\hline \multicolumn{7}{|l|}{ Variance terms } \\
\hline State intercepts & - & - & 0.000 & 0.000 & 0.000 & \\
\hline Ind. intercepts & - & - & 0.430 & 0.429 & 0.430 & \\
\hline Residuals & - & - & 0.369 & 0.368 & 0.358 & \\
\hline $\mathrm{N}$ & 37,656 & 24,812 & 38,146 & 38,146 & 25,111 & \\
\hline
\end{tabular}

Each column is a separate linear multilevel regression model. For the "monthly earnings" outcome, I adopt the Heckman selection model. I add all income values by 1 before taking a logarithm of the outcome. See Table 3 for sample and model specifications. Earning and family income values are expressed in January 1996 US dollars using the Consumer Price Index. Standard errors are in parentheses

${ }^{+} \mathrm{p}<0.10 . * \mathrm{p}<0.05 . * * \mathrm{p}<0.01 . * * * \mathrm{p}<.001$

Findings from this study show that welfare reform was associated with increased employment rates among single mothers by $3-6 \%$ points. This magnitude is similar to findings from earlier studies (Kaushal and Kaestner 2001; Grogger 2003; Fang and Keane 2004). This study further found that this employment rate increase was sustained even up to 10 years after the reform. The employment trend also indicates that, on average, the growth in employment occurred around the time of the welfare reform and peaked at 4-5 years after the reform (when some families reached their time limit), and employment rates did not show a clear trend of growth afterwards. Furthermore, the increase in labor supply in response to the welfare reform among single mothers was mostly at the extensive margin rather than at the intensive margin. The reform was not associated with changes in work hours among single mothers. Next, in regard to the impacts of policy stringencies, unlike their strong association with TANF participation, stringent policies did not lead to higher levels of employment. Work hours, however, show some increases 4-7 years after the reform in states with shorter time limits, with single mothers' work hours catching up with those of their counterparts in states without strict TANF policy rules.

While welfare reform was associated with more single mothers entering into employment and short time limit policies were associated with more work hours among single mothers, the trajectories of earnings and family income of single mothers were not distinct from those of married mothers. The null finding on family income is consistent with the mixed findings in prior studies (Ziliak 2016). The null finding on earnings is contrary to the study hypothesis. One would expect to see a higher growth in earnings specific to single mothers as they integrate into the labor market for two reasons. First, since this study shows that TANF was associated with sustained growth in employment and short time limit policies were associated with increases in work hours among single mothers, their levels of work experience and human capital should also increase, which would supposedly lead to an increase in earned income as time elapsed. Second, single mothers had lower earned income prior to the reform than did the mothers in the comparison group, so they had greater room for earned income growth. This finding regarding the lack of higher levels of earned income growth indicates that, although the welfare reform or short time limit policies pushed disadvantaged families off welfare and into employment or work for more hours, the earned income of single mothers did not increase as expected. The stagnation in earnings growth can potentially be explained by two factors. First, welfare recipients and welfare leavers often could only take on low-wage or low-quality jobs, and few successfully transitioned into full-time employment due to their limited skills and occupational-specific experience (Cancian and Meyer 2000; Johnson and Corcoran 2003). Second, Seefeldt (2008) found that some former welfare recipients faced difficulties in juggling work with family duties; hence, they had more obstacles in accepting 
Table 7 Trajectories of financial independence and policy stringencies

Financial independence

(No public or private assistance)

Full sample (1) State-specific trend

States with no waiver before 1996 (3)

$$
\begin{aligned}
& \text { Years since policy influence }(\text { YPI })(\text { Ref } \\
& 0-1 \text { year } \times \text { treat } \\
& \text { 2-3 year } \times \text { treat } \\
& \text { 4-5 year } \times \text { treat } \\
& \text { 6-7 year } \times \text { treat } \\
& \text { 8-10 year } \times \text { treat } \\
& \text { YPI } \times \text { sanction } \\
& 0-1 \text { year } \times \text { treat } \times \text { full sanction } \\
& \text { 2-3 year } \times \text { treat } \times \text { full sanction } \\
& \text { 4-5 year } \times \text { treat } \times \text { full sanction } \\
& \text { 8-10 year } \times \text { treat } \times<60 \text { month } \\
& \text { 6-7 year } \times \text { treat } \times \text { full sanction } \\
& \text { 8-10 year } \times \text { treat } \times \text { full sanction } \\
& \text { YPI } \times \text { time limit } \\
& 0-1 \text { year } \times \text { treat } \times<60 \text { month }
\end{aligned}
$$

Treat

Treat $\times$ full sanction

Treat $x<60$ month

Constant

Variance terms

$$
\text { State intercepts }
$$

Ind. intercepts

Residuals (2)

$0.043 * * *$
$(0.012)$

$0.107 * * *$

(0.015)

$0.111 * * *$

(0.018)

$0.111 * * *$

(0.018)

$0.094 * * *$

(0.020)

$0.037 * *$

$(0.013)$

$0.096 * * *$

(0.017)

$0.099 * * *$

(0.020)

$0.096 * * *$

(0.021)

$0.094 * * *$

(0.023)

0.005

0.007

(0.021)

(0.030)

0.010

0.024

0.007

(0.023)

(0.023)

(0.035)

$-0.028$

$-0.023$

0.011

$(0.034)$

$-0.013$

(0.033)

(0.034)

(0.053)

$-0.005$

0.028

(0.033)

(0.050)

$-0.018$

0.017

(0.035)

(0.035)

(0.052)

0.018

(0.028)

$0.077 * \wedge$

(0.031)

$0.090^{* \wedge \wedge}$

(0.044)

$0.114^{* * \wedge \wedge}$

0.019

0.015

(0.028)

$(0.040)$

$0.078 * \wedge$

0.075

(0.031)

(0.046)

$0.087 * \wedge$

0.078

(0.044)

(0.067)

$0.107^{* \wedge \wedge}$

0.082

(0.044)

(0.044)

(0.065)

$0.132 * * \wedge \wedge$

$0.126^{* * \wedge \wedge}$

0.071

(0.048)

(0.049)

(0.070)

$-0.153$

$-0.149$

$-0.191$

(0.131)

$-0.013$

(0.131)

(0.153)

$-0.017$

$-0.013$

(0.028)

(0.028)

(0.041)

$-0.070^{+}$

(0.036)

$-0.067^{+}$

$-0.042$

(0.053)

0.141

(0.328)

(0.301)

0.275

(0.355)

0.000

0.099

0.051 
Table 7 (continued)

\begin{tabular}{llll}
\hline & \multicolumn{2}{l}{$\begin{array}{l}\text { Financial independence } \\
\text { (No public or private assistance) }\end{array}$} \\
\cline { 2 - 4 } & Full sample (1) & $\begin{array}{l}\text { State-specific trend } \\
(2)\end{array}$ & $\begin{array}{l}\text { States with no waiver } \\
\text { before 1996 (3) }\end{array}$ \\
\hline $\mathrm{N}$ & 38,146 & 38,146 & 25,111 \\
\hline
\end{tabular}

Each column is a separate linear multilevel regression model. See Table 3 for sample and model specifications. Standard errors are in parentheses ${ }^{+} \mathrm{p}<0.10 . * \mathrm{p}<0.05$. $* * \mathrm{p}<0.01 . * * * \mathrm{p}<.001$

promotions that could increase their wages or had difficulties in securing a flexible job that could accommodate their caregiving duties (Seefeldt 2008).

Overall, the lack of differential effects between stringent and non-stringent policies in regard to increasing employment and earned income may be due to three factors: the "announcement effects" of the welfare reform (Blundell et al. 2011), the complexity of welfare policy information (Meyer 2002; Romich 2006), and the marked decrease in the TANF program's caseloads, which reduced the influence of TANF requirements on families (Loprest 2012; ACF 2018). First, most individuals across stringent and non-stringent states may have responded uniformly to the announcement of the introduction of welfare requirements, such as to the time limits and sanctions on noncompliance with work requirements, and shifted their work behaviors and welfare participation patterns around the time of the welfare reform. Individuals might be more responsive to the presence of the requirements than to the degree of requirement stringencies. Second, many low-income families did not possess precise or detailed information regarding policies' content, and they may have faced difficulties in determining an optimal behavioral response (e.g., the number of work hours) to policy stimuli (Meyer 2002; Romich 2006). Third, the marked decrease in TANF program caseloads since the welfare reform reduced the program's influence on families' lives. After the reform, many states attempted to reach the work participation benchmark by keeping caseloads small, reallocating their TANF grants away from traditional cash assistance, and making the program's features undesirable (Danziger et al. 2016; Haskins 2016). Many potential TANF recipients may presume that TANF is not available to support them (Edin and Shaefer 2015; Seefeldt and Sandstrom 2015). The degree to which the levels of TANF unavailability as an income alternative to families was similar across stringent and non-stringent states may explain the null findings of stringent TANF requirements on some outcomes. Furthermore, when comparing the stronger impacts of short time limits relative to work sanctions on SNAP participation ${ }^{34}$ and financial independence, this finding may suggest that the behavioral responses to short time limits were stronger or that policy information is more salient for time limit policies than for the degree of work sanctions.

The above findings should be interpreted with caution as racial differences in results indicate that experiences of racial minorities may be disguised in the main findings. This study finds that although the welfare reform reduced TANF participation among both Black and White single mothers, stringencies of sanction policies reduced welfare participation more among White single mothers than among Black single mothers. This finding suggests that the reform uniformly affected Black single mothers, regardless of the harshness of sanction policies in their state of residence, whereas the effects on White single mothers were more contingent upon the specific stringency of sanction policies. This trend can be explained by the fact that the implementation of sanction policies disproportionally target Black welfare recipients at a higher rate (Keiser et al. 2004; Schram et al. 2009), so Black single mothers might have already been affected when a state had any partial sanction policies. In contrast, the sanctioning experiences of White single mothers were more reflective of the specific stringency of sanction policies. With respect to employment, the reform increased employment rates among Black single mothers 4 years after TANF's implementation, but this increase was not reflected in family income. The lack of increases in earnings reflects Black mothers' precarious experience after the welfare reform, often leading them to take on low-paying jobs and to be trapped in poverty (Johnson 2010). The differential results by race pointed to additional disadvantages experienced by racial minorities since the welfare reform, which may be perpetuating social inequality. This finding suggests the

\footnotetext{
${ }^{34}$ As states implemented TANF policies, they avoided establishing new TANF cases by meeting one-time needs or providing rapid job placement, leading to discouraging or not promoting SNAP application (Wiseman 2002).
} 
Table 8 Trajectories of welfare participation, financial independence, and policy stringencies by race

\begin{tabular}{|c|c|c|c|c|c|c|c|c|}
\hline \multirow[t]{2}{*}{ Sample } & \multicolumn{2}{|c|}{ TANF participation } & \multicolumn{2}{|c|}{ SNAP participation } & \multicolumn{2}{|c|}{ SSI participation } & \multicolumn{2}{|c|}{ Financial independence } \\
\hline & White & Black & White & Black & Jhite & Black & Vhite & Black \\
\hline \multicolumn{9}{|c|}{ Years since policy influence (YPI) (reference: -2 to -1 year) } \\
\hline $0-1$ year $\times$ treat & $\begin{array}{l}-0.033 * * * \\
(0.009)\end{array}$ & $\begin{array}{l}-0.052 \\
(0.035)\end{array}$ & $\begin{array}{l}-0.044^{* *} \\
(0.013)\end{array}$ & $\begin{array}{l}-0.030 \\
(0.040)\end{array}$ & $\begin{array}{l}0.005 \\
(0.007)\end{array}$ & $\begin{array}{l}0.016 \\
(0.026)\end{array}$ & $\begin{array}{l}0.049 * * * \\
(0.014)\end{array}$ & $\begin{array}{l}0.052 \\
(0.039)\end{array}$ \\
\hline $2-3$ year $\times$ treat & $\begin{array}{l}-0.087 * * * \\
(0.011)\end{array}$ & $\begin{array}{l}-0.195^{* * *} \\
(0.041)\end{array}$ & $\begin{array}{l}-0.110 * * * \\
(0.017)\end{array}$ & $\begin{array}{l}-0.113 * \\
(0.048)\end{array}$ & $\begin{array}{l}0.003 \\
(0.009)\end{array}$ & $\begin{array}{l}-0.022 \\
(0.032)\end{array}$ & $\begin{array}{l}0.115 * * * \\
(0.018)\end{array}$ & $\begin{array}{l}0.133 * * \\
(0.047)\end{array}$ \\
\hline $4-5$ year $\times$ treat & $\begin{array}{l}-0.111 * * * \\
(0.013)\end{array}$ & $\begin{array}{l}-0.271 * * * \\
(0.046)\end{array}$ & $\begin{array}{l}-0.093 * * * \\
(0.020)\end{array}$ & $\begin{array}{l}-0.100^{+} \\
(0.056)\end{array}$ & $\begin{array}{l}0.018 \\
(0.011)\end{array}$ & $\begin{array}{l}-0.025 \\
(0.038)\end{array}$ & $\begin{array}{l}0.092 * * * \\
(0.021)\end{array}$ & $\begin{array}{l}0.156 * * \\
(0.055)\end{array}$ \\
\hline $6-7$ year $\times$ treat & $\begin{array}{l}-0.130 * * * \\
(0.013)\end{array}$ & $\begin{array}{l}-0.287^{* * *} \\
(0.047)\end{array}$ & $\begin{array}{l}-0.094^{* * *} \\
(0.021)\end{array}$ & $\begin{array}{l}-0.038 \\
(0.058)\end{array}$ & $\begin{array}{l}0.013 \\
(0.012)\end{array}$ & $\begin{array}{l}-0.047 \\
(0.041)\end{array}$ & $\begin{array}{l}0.103 * * * \\
(0.022)\end{array}$ & $\begin{array}{l}0.097^{+} \\
(0.057)\end{array}$ \\
\hline $8-10$ year $\times$ treat & $\begin{array}{l}-0.135 * * * \\
(0.014)\end{array}$ & $\begin{array}{l}-0.246^{* * *} \\
(0.053)\end{array}$ & $\begin{array}{l}-0.066^{* *} \\
(0.022)\end{array}$ & $\begin{array}{l}-0.084 \\
(0.065)\end{array}$ & $\begin{array}{l}0.033 * \\
(0.013)\end{array}$ & $\begin{array}{l}-0.029 \\
(0.046)\end{array}$ & $\begin{array}{l}0.076^{* *} \\
(0.024)\end{array}$ & $\begin{array}{l}0.120^{+} \\
(0.064)\end{array}$ \\
\hline \multicolumn{9}{|l|}{ YPI $\times$ sanction } \\
\hline $0-1$ year $\times$ treat $\times$ full sanction & $\begin{array}{l}-0.040 * \\
(0.016)\end{array}$ & $\begin{array}{l}-0.061 \\
(0.050)\end{array}$ & $\begin{array}{l}0.012 \\
(0.025)\end{array}$ & $\begin{array}{l}-0.101^{+} \\
(0.057)\end{array}$ & $\begin{array}{l}-0.009 \\
(0.013)\end{array}$ & $\begin{array}{l}-0.052 \\
(0.037)\end{array}$ & $\begin{array}{l}-0.017 \\
(0.026)\end{array}$ & $\begin{array}{l}0.061 \\
(0.055)\end{array}$ \\
\hline $2-3$ year $\times$ treat $\times$ full sanction & $\begin{array}{l}-0.065^{* * *} \\
(0.018)\end{array}$ & $\begin{array}{l}-0.102^{+} \\
(0.056)\end{array}$ & $\begin{array}{l}0.014 \\
(0.027)\end{array}$ & $\begin{array}{l}-0.077 \\
(0.065)\end{array}$ & $\begin{array}{l}-0.028^{+} \\
(0.014)\end{array}$ & $\begin{array}{l}-0.011 \\
(0.043)\end{array}$ & $\begin{array}{l}0.003 \\
(0.028)\end{array}$ & $\begin{array}{l}0.003 \\
(0.063)\end{array}$ \\
\hline $4-5$ year $\times$ treat $\times$ full sanction & $\begin{array}{l}-0.044^{+} \\
(0.025)\end{array}$ & $\begin{array}{l}0.004 \\
(0.073)\end{array}$ & $\begin{array}{l}-0.010 \\
(0.039)\end{array}$ & $\begin{array}{l}0.065 \\
(0.089)\end{array}$ & $\begin{array}{l}-0.069 * * \\
(0.023)\end{array}$ & $\begin{array}{l}0.014 \\
(0.063)\end{array}$ & $\begin{array}{l}0.043 \\
(0.041)\end{array}$ & $\begin{array}{l}-0.162^{+} \\
(0.088)\end{array}$ \\
\hline $6-7$ year $\times$ treat $\times$ full sanction & $\begin{array}{l}-0.060 * \\
(0.023)\end{array}$ & $\begin{array}{l}-0.007 \\
(0.070)\end{array}$ & $\begin{array}{l}-0.015 \\
(0.038)\end{array}$ & $\begin{array}{l}-0.045 \\
(0.086)\end{array}$ & $\begin{array}{l}-0.029 \\
(0.023)\end{array}$ & $\begin{array}{l}0.086 \\
(0.062)\end{array}$ & $\begin{array}{l}0.032 \\
(0.040)\end{array}$ & $\begin{array}{l}-0.092 \\
(0.085)\end{array}$ \\
\hline $8-10$ year $\times$ treat $\times$ full sanction & $\begin{array}{l}-0.037 \\
(0.025)\end{array}$ & $\begin{array}{l}-0.031 \\
(0.076)\end{array}$ & $\begin{array}{l}-0.042 \\
(0.040)\end{array}$ & $\begin{array}{l}0.061 \\
(0.094)\end{array}$ & $\begin{array}{l}-0.032 \\
(0.024)\end{array}$ & $\begin{array}{l}0.052 \\
(0.068)\end{array}$ & $\begin{array}{l}0.045 \\
(0.043)\end{array}$ & $\begin{array}{l}-0.189 * \\
(0.093)\end{array}$ \\
\hline \multicolumn{9}{|l|}{ YPI $\times$ time limit } \\
\hline $0-1$ year $\times$ treat $\times<60$ month & $\begin{array}{l}-0.017 \\
(0.024)\end{array}$ & $\begin{array}{l}0.051 \\
(0.063)\end{array}$ & $\begin{array}{l}-0.050 \\
(0.036)\end{array}$ & $\begin{array}{l}-0.064 \\
(0.073)\end{array}$ & $\begin{array}{l}-0.001 \\
(0.019)\end{array}$ & $\begin{array}{l}-0.056 \\
(0.047)\end{array}$ & $\begin{array}{l}0.014 \\
(0.037)\end{array}$ & $\begin{array}{l}0.001 \\
(0.070)\end{array}$ \\
\hline $2-3$ year $\times$ treat $x<60$ month & $\begin{array}{l}-0.060 * \\
(0.026)\end{array}$ & $\begin{array}{l}-0.034 \\
(0.071)\end{array}$ & $\begin{array}{l}-0.064 \\
(0.039)\end{array}$ & $\begin{array}{l}-0.172 * \\
(0.082)\end{array}$ & $\begin{array}{l}-0.028 \\
(0.021)\end{array}$ & $\begin{array}{l}-0.040 \\
(0.054)\end{array}$ & $\begin{array}{l}0.039 \\
(0.040)\end{array}$ & $\begin{array}{l}0.112 \\
(0.079)\end{array}$ \\
\hline $4-5$ year $\times$ treat $x<60$ month & $\begin{array}{l}-0.039 \\
(0.034)\end{array}$ & $\begin{array}{l}0.051 \\
(0.087)\end{array}$ & $\begin{array}{l}-0.093^{+} \\
(0.054)\end{array}$ & $\begin{array}{l}-0.142 \\
(0.106)\end{array}$ & $\begin{array}{l}-0.061^{+} \\
(0.031)\end{array}$ & $\begin{array}{l}-0.003 \\
(0.074)\end{array}$ & $\begin{array}{l}0.097^{+} \\
(0.057)\end{array}$ & $\begin{array}{l}0.097 \\
(0.104)\end{array}$ \\
\hline $6-7$ year $\times$ treat $x<60$ month & $\begin{array}{l}-0.045 \\
(0.033)\end{array}$ & $\begin{array}{l}0.040 \\
(0.087)\end{array}$ & $\begin{array}{l}-0.127 * \\
(0.053)\end{array}$ & $\begin{array}{l}-0.153 \\
(0.106)\end{array}$ & $\begin{array}{l}-0.056^{+} \\
(0.031)\end{array}$ & $\begin{array}{l}-0.006 \\
(0.075)\end{array}$ & $\begin{array}{l}0.131 * \\
(0.056)\end{array}$ & $\begin{array}{l}0.117 \\
(0.105)\end{array}$ \\
\hline $8-10$ year $\times$ treat $x<60$ month & $\begin{array}{l}-0.032 \\
(0.036)\end{array}$ & $\begin{array}{l}-0.082 \\
(0.099)\end{array}$ & $\begin{array}{l}-0.182^{* *} \\
(0.058)\end{array}$ & $\begin{array}{l}-0.167 \\
(0.121)\end{array}$ & $\begin{array}{l}-0.063^{+} \\
(0.034)\end{array}$ & $\begin{array}{l}0.092 \\
(0.086)\end{array}$ & $\begin{array}{l}0.171 * * \\
(0.061)\end{array}$ & $\begin{array}{l}0.117 \\
(0.120)\end{array}$ \\
\hline Treat & $\begin{array}{l}-0.331 * * * \\
(0.096)\end{array}$ & $\begin{array}{l}-0.216 \\
(0.296)\end{array}$ & $\begin{array}{l}-0.029 \\
(0.158)\end{array}$ & $\begin{array}{l}0.281 \\
(0.384)\end{array}$ & $\begin{array}{l}0.051 \\
(0.105)\end{array}$ & $\begin{array}{l}-0.026 \\
(0.299)\end{array}$ & $\begin{array}{l}0.060 \\
(0.171)\end{array}$ & $\begin{array}{l}-0.327 \\
(0.387)\end{array}$ \\
\hline Treat $\times$ full sanction & $\begin{array}{l}0.070 * * * \\
(0.020)\end{array}$ & $\begin{array}{l}0.036 \\
(0.056)\end{array}$ & $\begin{array}{l}0.033 \\
(0.032)\end{array}$ & $\begin{array}{l}-0.018 \\
(0.070)\end{array}$ & $\begin{array}{l}0.057 * * \\
(0.020)\end{array}$ & $\begin{array}{l}-0.028 \\
(0.053)\end{array}$ & $\begin{array}{l}-0.058^{+} \\
(0.034)\end{array}$ & $\begin{array}{l}0.082 \\
(0.070)\end{array}$ \\
\hline Treat $\times<60$ month & $\begin{array}{l}0.020 \\
(0.027)\end{array}$ & $\begin{array}{l}-0.027 \\
(0.073)\end{array}$ & $\begin{array}{l}0.088^{*} \\
(0.044)\end{array}$ & $\begin{array}{l}0.094 \\
(0.091)\end{array}$ & $\begin{array}{l}0.019 \\
(0.027)\end{array}$ & $\begin{array}{l}0.067 \\
(0.067)\end{array}$ & $\begin{array}{l}-0.068 \\
(0.046)\end{array}$ & $\begin{array}{l}-0.076 \\
(0.090)\end{array}$ \\
\hline Constant & $\begin{array}{l}0.145 \\
(0.202)\end{array}$ & $\begin{array}{l}1.477 * \\
(0.709)\end{array}$ & $\begin{array}{l}0.466 \\
(0.318)\end{array}$ & $\begin{array}{l}1.823^{*} \\
(0.859)\end{array}$ & $\begin{array}{l}-0.207 \\
(0.179)\end{array}$ & $\begin{array}{l}0.683 \\
(0.600)\end{array}$ & $\begin{array}{l}0.584^{+} \\
(0.333)\end{array}$ & $\begin{array}{l}-0.503 \\
(0.845)\end{array}$ \\
\hline $\mathrm{N}$ & 26,231 & 7051 & 26,231 & 7051 & 26,231 & 7051 & 26,231 & 7051 \\
\hline
\end{tabular}

Each column is a separate linear multilevel regression model. See Table 3 for sample and model specifications. Standard errors are in parentheses ${ }^{+} \mathrm{p}<0.10 . * \mathrm{p}<0.05 . * * \mathrm{p}<0.01 . * * * \mathrm{p}<.001$ 
Table 9 Trajectories of work, income and policy stringencies by race

\begin{tabular}{|c|c|c|c|c|c|c|c|}
\hline \multirow[t]{2}{*}{ Sample } & \multicolumn{2}{|c|}{ Employment } & \multicolumn{2}{|c|}{$\begin{array}{l}\text { Average monthly work } \\
\text { hours }\end{array}$} & \multirow{2}{*}{$\begin{array}{l}\text { Log (monthly earnings) } \\
\text { White }\end{array}$} & \multicolumn{2}{|c|}{$\begin{array}{l}\text { Log (monthly family } \\
\text { income) }\end{array}$} \\
\hline & White & Black & White & Black & & White & Black \\
\hline \multicolumn{8}{|c|}{ Years since policy influence (YPI) (reference: -2 to -1 year) } \\
\hline $0-1$ year $\times$ treat & $\begin{array}{l}0.059 * * * \\
(0.018)\end{array}$ & $\begin{array}{l}-0.028 \\
(0.045)\end{array}$ & $\begin{array}{l}-5.195 \\
(3.963)\end{array}$ & $\begin{array}{l}15.158^{+} \\
(8.371)\end{array}$ & $\begin{array}{l}-0.087 \\
(0.069)\end{array}$ & $\begin{array}{l}0.061^{+} \\
(0.036)\end{array}$ & $\begin{array}{l}-0.220^{*} \\
(0.111)\end{array}$ \\
\hline $2-3$ year $\times$ treat & $\begin{array}{l}0.045^{*} \\
(0.023)\end{array}$ & $\begin{array}{l}0.080 \\
(0.054)\end{array}$ & $\begin{array}{l}-2.843 \\
(4.937)\end{array}$ & $\begin{array}{l}13.095 \\
(9.595)\end{array}$ & $\begin{array}{l}-0.046 \\
(0.085)\end{array}$ & $\begin{array}{l}0.003 \\
(0.045)\end{array}$ & $\begin{array}{l}-0.181 \\
(0.130)\end{array}$ \\
\hline $4-5$ year $\times$ treat & $\begin{array}{l}0.042 \\
(0.027)\end{array}$ & $\begin{array}{l}0.133 * \\
(0.061)\end{array}$ & $\begin{array}{l}-6.498 \\
(5.457)\end{array}$ & $\begin{array}{l}3.235 \\
(9.883)\end{array}$ & $\begin{array}{l}-0.012 \\
(0.095)\end{array}$ & $\begin{array}{l}-0.002 \\
(0.053)\end{array}$ & $\begin{array}{l}0.143 \\
(0.146)\end{array}$ \\
\hline $6-7$ year $\times$ treat & $\begin{array}{l}0.007 \\
(0.028)\end{array}$ & $\begin{array}{l}0.144 * \\
(0.063)\end{array}$ & $\begin{array}{l}-5.116 \\
(5.200)\end{array}$ & $\begin{array}{l}10.735 \\
(10.244)\end{array}$ & $\begin{array}{l}0.100 \\
(0.093)\end{array}$ & $\begin{array}{l}-0.008 \\
(0.054)\end{array}$ & $\begin{array}{l}0.044 \\
(0.148)\end{array}$ \\
\hline $8-10$ year $\times$ treat & $\begin{array}{l}0.023 \\
(0.030)\end{array}$ & $\begin{array}{l}0.077 \\
(0.070)\end{array}$ & $\begin{array}{l}-8.380 \\
(5.438)\end{array}$ & $\begin{array}{l}11.896 \\
(10.317)\end{array}$ & $\begin{array}{l}-0.024 \\
(0.100)\end{array}$ & $\begin{array}{l}-0.056 \\
(0.058)\end{array}$ & $\begin{array}{l}0.018 \\
(0.166)\end{array}$ \\
\hline \multicolumn{8}{|l|}{ YPI $\times$ sanction } \\
\hline $0-1$ year $\times$ treat $\times$ full sanction & $\begin{array}{l}0.007 \\
(0.033)\end{array}$ & $\begin{array}{l}0.120^{+} \\
(0.065)\end{array}$ & $\begin{array}{l}-1.194 \\
(7.315)\end{array}$ & $\begin{array}{l}-7.661 \\
(12.110)\end{array}$ & $\begin{array}{l}-0.036 \\
(0.130)\end{array}$ & $\begin{array}{l}0.010 \\
(0.066)\end{array}$ & $\begin{array}{l}0.185 \\
(0.159)\end{array}$ \\
\hline $2-3$ year $\times$ treat $\times$ full sanction & $\begin{array}{l}0.007 \\
(0.036)\end{array}$ & $\begin{array}{l}-0.049 \\
(0.073)\end{array}$ & $\begin{array}{l}-1.864 \\
(8.768)\end{array}$ & $\begin{array}{l}-10.573 \\
(13.347)\end{array}$ & $\begin{array}{l}\text { v0.031 } \\
(0.153)\end{array}$ & $\begin{array}{l}0.014 \\
(0.072)\end{array}$ & $\begin{array}{l}0.113 \\
(0.178)\end{array}$ \\
\hline $4-5$ year $\times$ treat $\times$ full sanction & $\begin{array}{l}0.029 \\
(0.052)\end{array}$ & $\begin{array}{l}-0.249 * * \\
(0.097)\end{array}$ & $\begin{array}{l}-7.115 \\
(10.616)\end{array}$ & $\begin{array}{l}-4.965 \\
(15.663)\end{array}$ & $\begin{array}{l}-0.105 \\
(0.177)\end{array}$ & $\begin{array}{l}0.239 * \\
(0.101)\end{array}$ & $\begin{array}{l}-0.174 \\
(0.228)\end{array}$ \\
\hline $6-7$ year $\times$ treat $\times$ full sanction & $\begin{array}{l}0.052 \\
(0.050)\end{array}$ & $\begin{array}{l}-0.192 * \\
(0.092)\end{array}$ & $\begin{array}{l}-6.912 \\
(9.660)\end{array}$ & $\begin{array}{l}-8.723 \\
(14.017)\end{array}$ & $\begin{array}{l}-0.192 \\
(0.159)\end{array}$ & $\begin{array}{l}0.101 \\
(0.095)\end{array}$ & $\begin{array}{l}-0.009 \\
(0.216)\end{array}$ \\
\hline $8-10$ year $\times$ treat $\times$ full sanction & $\begin{array}{l}0.033 \\
(0.054)\end{array}$ & $\begin{array}{l}-0.222^{*} \\
(0.100)\end{array}$ & $\begin{array}{l}-0.555 \\
(10.082)\end{array}$ & $\begin{array}{l}-14.305 \\
(14.468)\end{array}$ & $\begin{array}{l}-0.060 \\
(0.169)\end{array}$ & $\begin{array}{l}0.113 \\
(0.102)\end{array}$ & $\begin{array}{l}-0.018 \\
(0.234)\end{array}$ \\
\hline \multicolumn{8}{|l|}{ YPI $\times$ time limit } \\
\hline $0-1$ year $\times$ treat $\times<60$ month & $\begin{array}{l}-0.030 \\
(0.048)\end{array}$ & $\begin{array}{l}-0.051 \\
(0.083)\end{array}$ & $\begin{array}{l}15.602 \\
(10.431)\end{array}$ & $\begin{array}{l}2.203 \\
(14.260)\end{array}$ & $\begin{array}{l}0.076 \\
(0.172)\end{array}$ & $\begin{array}{l}-0.238 * \\
(0.096)\end{array}$ & $\begin{array}{l}0.044 \\
(0.203)\end{array}$ \\
\hline $2-3$ year $\times$ treat $x<60$ month & $\begin{array}{l}0.001 \\
(0.052)\end{array}$ & $\begin{array}{l}0.008 \\
(0.092)\end{array}$ & $\begin{array}{l}13.407 \\
(13.180)\end{array}$ & $\begin{array}{l}9.361 \\
(16.613)\end{array}$ & $\begin{array}{l}0.087 \\
(0.213)\end{array}$ & $\begin{array}{l}0.073 \\
(0.104)\end{array}$ & $\begin{array}{l}-0.114 \\
(0.225)\end{array}$ \\
\hline $4-5$ year $\times$ treat $x<60$ month & $\begin{array}{l}0.058 \\
(0.072)\end{array}$ & $\begin{array}{l}-0.032 \\
(0.115)\end{array}$ & $\begin{array}{l}24.232^{+} \\
(13.583)\end{array}$ & $\begin{array}{l}32.157^{+} \\
(19.464)\end{array}$ & $\begin{array}{l}0.097 \\
(0.245)\end{array}$ & $\begin{array}{l}0.119 \\
(0.139)\end{array}$ & $\begin{array}{l}-0.160 \\
(0.272)\end{array}$ \\
\hline $6-7$ year $\times$ treat $\times<60$ month & $\begin{array}{l}-0.033 \\
(0.070)\end{array}$ & $\begin{array}{l}-0.154 \\
(0.115)\end{array}$ & $\begin{array}{l}30.166 * \\
(12.460)\end{array}$ & $\begin{array}{l}31.169^{+} \\
(18.166)\end{array}$ & $\begin{array}{l}0.314 \\
(0.218)\end{array}$ & $\begin{array}{l}-0.126 \\
(0.135)\end{array}$ & $\begin{array}{l}-0.242 \\
(0.270)\end{array}$ \\
\hline $8-10$ year $\times$ treat $\times<60$ month & $\begin{array}{l}-0.071 \\
(0.077)\end{array}$ & $\begin{array}{l}-0.051 \\
(0.131)\end{array}$ & $\begin{array}{l}22.941^{+} \\
(13.593)\end{array}$ & $\begin{array}{l}29.328 \\
(19.540)\end{array}$ & $\begin{array}{l}0.258 \\
(0.235)\end{array}$ & $\begin{array}{l}-0.170 \\
(0.147)\end{array}$ & $\begin{array}{l}-0.165 \\
(0.307)\end{array}$ \\
\hline Treat & $\begin{array}{l}-0.304 \\
(0.213)\end{array}$ & $\begin{array}{l}0.285 \\
(0.396)\end{array}$ & $\begin{array}{l}-8.555 \\
(30.733)\end{array}$ & $\begin{array}{l}-41.400 \\
(53.330)\end{array}$ & $\begin{array}{l}0.733 \\
(0.548)\end{array}$ & $\begin{array}{l}-0.432 \\
(0.392)\end{array}$ & $\begin{array}{l}0.597 \\
(0.899)\end{array}$ \\
\hline Treat $\times$ full sanction & $\begin{array}{l}-0.066 \\
(0.043)\end{array}$ & $\begin{array}{l}0.043 \\
(0.075)\end{array}$ & $\begin{array}{l}0.320 \\
(8.600)\end{array}$ & $\begin{array}{l}9.138 \\
(11.545)\end{array}$ & $\begin{array}{l}0.113 \\
(0.130)\end{array}$ & $\begin{array}{l}-0.169 * \\
(0.080)\end{array}$ & $\begin{array}{l}-0.039 \\
(0.173)\end{array}$ \\
\hline Treat $\times<60$ month & $\begin{array}{l}0.064 \\
(0.058)\end{array}$ & $\begin{array}{l}0.044 \\
(0.096)\end{array}$ & $\begin{array}{l}-19.336^{+} \\
(11.011)\end{array}$ & $\begin{array}{l}-21.249 \\
(15.940)\end{array}$ & $\begin{array}{l}-0.307^{+} \\
(0.178)\end{array}$ & $\begin{array}{l}0.125 \\
(0.110)\end{array}$ & $\begin{array}{l}0.027 \\
(0.224)\end{array}$ \\
\hline Constant & $\begin{array}{l}1.195 * * \\
(0.424)\end{array}$ & $\begin{array}{l}0.826 \\
(0.936)\end{array}$ & $\begin{array}{l}16.455 \\
(80.294)\end{array}$ & $\begin{array}{l}313.441 * \\
(149.217)\end{array}$ & $\begin{array}{l}4.055 * * \\
(1.466)\end{array}$ & $\begin{array}{l}7.696 * * * \\
(0.822)\end{array}$ & $\begin{array}{l}10.252^{* * *} \\
(2.211)\end{array}$ \\
\hline $\mathrm{N}$ & 26,231 & 7051 & 26,231 & 7051 & 25,830 & 26,231 & 7051 \\
\hline
\end{tabular}

Each column is a separate linear multilevel regression model. See Tables 5 and 6 for sample and model specifications. The model for monthly earnings among Black single mothers did not converge. Standard errors are in parentheses

${ }^{+} \mathrm{p}<0.10 .{ }^{*} \mathrm{p}<0.05 .{ }^{* *} \mathrm{p}<0.01 . * * * \mathrm{p}<.001$ 
imminence of further scrutiny and reform of the policy implementation process.

\section{Conclusion}

In conclusion, this study extends prior TANF literature in following low-skilled single mothers' trajectories of welfare use, labor supply, and income up to 10 years after the welfare reform. Furthermore, this study examines how stringencies of work sanction and time limit policies are related to long-term outcomes. The findings reveal that welfare reform was strongly associated with reduced welfare use (TANF and SNAP programs) and increased employment and financial independence even up to 10 years after the reform. Stringent policies (a full sanction upon the initial incidence of noncompliance with the work requirement or a short lifetime limit [below 60 months] of TANF receipt) were strongly associated with further reductions in TANF participation rates. However, only short time limits were associated with a further decrease in the SNAP participation rate and an increase in financial independence. Stringent policies were not associated with increases in levels of employment, earnings or family income. These findings suggest that although stricter work sanctions and shorter time limits were effective in driving down welfare rolls relative to more lenient state rules, they were not effective in increasing earnings and income for disadvantaged families in the long term. These findings provide evidence for policy discussions on restructuring welfare rules and for state assessment of the cost-effectiveness of employing stringent policies. Also, findings from this study demonstrated that stringent requirements are not effective in encouraging families to achieve longterm economic self-sufficiency, and they impose psychological burdens on disadvantaged families (Cheng 2007), so the necessity of adopting harsh measures warrants reevaluation. Furthermore, many countries around the world (the United Kingdom, Ireland, Denmark, Canada, New Zealand) have increased the stringency of workfare conditions and severity of sanctions (Fletcher 2020). The findings also contribute to an initial understanding of the long-term effects of welfare conditionalities to inform policy decisions.

Acknowledgement I acknowledge the grant support from the Studying Abroad Scholarship from the Ministry of Education, Republic of China (Taiwan). I also thank Neeraj Kaushal, Julien Teitler, Irwin Garfinkel, Yao Lu, Prakash Gorroochurn, and anonymous reviewers for valuable suggestions at various stages of this project.

\section{Appendix 1}

See Table 10. 
Table 10 Difference-in-difference assumption check

\begin{tabular}{|c|c|c|c|c|}
\hline & $\begin{array}{l}\text { All sample } \\
\text { (1) }\end{array}$ & $\begin{array}{l}\text { States that did not implement } \\
\text { any waiver policy before } 1996 \\
(2)\end{array}$ & $\begin{array}{l}\text { All sample } \\
\text { (1) }\end{array}$ & $\begin{array}{l}\text { States that did not implement } \\
\text { any waiver policy before } 1996 \\
\text { (2) }\end{array}$ \\
\hline Outcomes & \multicolumn{2}{|l|}{ TANF } & \multicolumn{2}{|l|}{ SNAP } \\
\hline Treat & $\begin{array}{l}0.195 * * * \\
(0.019)\end{array}$ & $\begin{array}{l}0.201 * * * \\
(0.024)\end{array}$ & $\begin{array}{l}0.295 * * * \\
(0.022)\end{array}$ & $\begin{array}{l}0.310 * * * \\
(0.027)\end{array}$ \\
\hline Trend & $\begin{array}{l}0.015 * * * \\
(0.003)\end{array}$ & $\begin{array}{l}0.020 * * * \\
(0.003)\end{array}$ & $\begin{array}{l}0.014 * * * \\
(0.003)\end{array}$ & $\begin{array}{l}0.017 * * * \\
(0.004)\end{array}$ \\
\hline Trend $\times$ treat & $\begin{array}{l}0.007 * \\
(0.004)\end{array}$ & $\begin{array}{l}0.006 \\
(0.005)\end{array}$ & $\begin{array}{l}0.011 * \\
(0.004)\end{array}$ & $\begin{array}{l}0.002 \\
(0.005)\end{array}$ \\
\hline $\mathrm{N}$ & 7707 & 5067 & 7707 & 5067 \\
\hline Outcomes & \multicolumn{2}{|l|}{ SSI } & \multicolumn{2}{|l|}{ Employment } \\
\hline Treat & $\begin{array}{l}0.042 * * * \\
(0.012)\end{array}$ & $\begin{array}{l}0.048 * * \\
(0.015)\end{array}$ & $\begin{array}{l}-0.057^{+} \\
(0.030)\end{array}$ & $\begin{array}{l}-0.065^{+} \\
(0.037)\end{array}$ \\
\hline Trend & $\begin{array}{l}0.002 \\
(0.002)\end{array}$ & $\begin{array}{l}0.003 \\
(0.002)\end{array}$ & $\begin{array}{l}-0.004 \\
(0.004)\end{array}$ & $\begin{array}{l}-0.003 \\
(0.005)\end{array}$ \\
\hline Trend $\times$ treat & $\begin{array}{l}0.004^{+} \\
(0.002)\end{array}$ & $\begin{array}{l}0.003 \\
(0.003)\end{array}$ & $\begin{array}{l}-0.001 \\
(0.006)\end{array}$ & $\begin{array}{l}-0.001 \\
(0.007)\end{array}$ \\
\hline $\mathrm{N}$ & 7707 & 5067 & 7707 & 5067 \\
\hline Outcomes & \multicolumn{2}{|c|}{ Average monthly work hours } & \multicolumn{2}{|c|}{ Log (monthly earnings) } \\
\hline Treat & $\begin{array}{l}-11.560^{*} \\
(5.463)\end{array}$ & $\begin{array}{l}-10.687 \\
(6.587)\end{array}$ & $\begin{array}{l}-0.632 * * \\
(0.199)\end{array}$ & $\begin{array}{l}-0.604 * \\
(0.247)\end{array}$ \\
\hline Trend & $\begin{array}{l}2.368 * * \\
(0.725)\end{array}$ & $\begin{array}{l}2.944 * * * \\
(0.869)\end{array}$ & $\begin{array}{l}0.146 * * * \\
(0.027)\end{array}$ & $\begin{array}{l}0.160 * * * \\
(0.033)\end{array}$ \\
\hline Trend $\times$ treat & $\begin{array}{l}2.107 * \\
(1.033)\end{array}$ & $\begin{array}{l}1.226 \\
(1.225)\end{array}$ & $\begin{array}{l}0.043 \\
(0.038)\end{array}$ & $\begin{array}{l}0.031 \\
(0.046)\end{array}$ \\
\hline $\mathrm{N}$ & 7707 & 5067 & 7707 & 5067 \\
\hline Outcomes & \multicolumn{2}{|c|}{ Log (family income) } & \multicolumn{2}{|c|}{ Financial independence } \\
\hline Treat & $\begin{array}{l}-0.609 * * * \\
(0.077)\end{array}$ & $\begin{array}{l}-0.704 * * * \\
(0.089)\end{array}$ & $\begin{array}{l}-0.346^{* * * *} \\
(0.023)\end{array}$ & $\begin{array}{l}-0.341 * * * \\
(0.029)\end{array}$ \\
\hline Trend & $\begin{array}{l}0.100 * * * \\
(0.013)\end{array}$ & $\begin{array}{l}0.088 * * * \\
(0.015)\end{array}$ & $\begin{array}{l}-0.012 * * * \\
(0.003)\end{array}$ & $\begin{array}{l}-0.015^{* * *} \\
(0.004)\end{array}$ \\
\hline Trend $\times$ treat & $\begin{array}{l}-0.014 \\
(0.016)\end{array}$ & $\begin{array}{l}0.003 \\
(0.018)\end{array}$ & $\begin{array}{l}-0.003 \\
(0.004)\end{array}$ & $\begin{array}{l}0.003 \\
(0.005)\end{array}$ \\
\hline $\mathrm{N}$ & 7707 & 5067 & 7707 & 5067 \\
\hline
\end{tabular}

Each column for each outcome is a separate linear multilevel regression model. See Table 2 for sample specifications. This analysis includes only observations before August 1996, the month of PRWORA announcement. The unit of analysis is person-quarter observation; hence, unlike the main analysis, the outcomes vary by quarter. The analytic sample only includes women who had a child at time of the survey. For the "Treat" variable, those who were not currently married in a given quarter were coded as 1 , otherwise 0 . The "Trend" variable is a linear variable representing the number of quarters ( 9 quarters before August 1996 was coded as 0 and 1 quarter before August 1996 was coded as 9). In model (1), all respondents were included in the analysis. In model (2), respondents living in states that have implemented a waiver policy prior to 1996 were excluded. All models control for women's race [White (ref.), Black, Hispanic, and other race], age of the youngest child in the panel [0-2 (ref.), $>2$ to $<5,6$ to $<12,12$ to 18], age in categories [18-24 (ref.), 25-29, 30-34, 35-39, 40-45, 45-49, 50-57], household size [1, 2, 3 or 4 (ref.), 5 or more], number of children [1, 2 (ref.), and 3 or more], unemployment rates in state s and year t, and state fixed effects. Standard errors are in parentheses

${ }^{+} \mathrm{p}<0.10 . * \mathrm{p}<0.05 . * * \mathrm{p}<0.01 . * * * \mathrm{p}<.001$ 


\section{Appendix 2}

See Tables 11, 12, 13, 14, 15, 16, 17 and 18 .

Table 11 First-difference results and sensitivity analyses-trajectories of TANF participation and policy stringencies

\begin{tabular}{|c|c|c|c|c|c|c|}
\hline & \multicolumn{6}{|c|}{ TANF participation } \\
\hline & \multicolumn{2}{|c|}{ First-difference } & \multicolumn{4}{|l|}{ DDD } \\
\hline & $\begin{array}{l}\text { Treatment: } \\
\text { Single } \\
\text { mothers } \\
(1)\end{array}$ & $\begin{array}{l}\text { Comparison: } \\
\text { Married } \\
\text { mothers } \\
(2)\end{array}$ & $\begin{array}{l}\text { Women arrived } \\
\text { in the state } \\
\text { before } 1992 \\
\text { (3) }\end{array}$ & $\begin{array}{l}\text { Women } \\
\text { responded in all } \\
\text { survey years } \\
\text { (4) }\end{array}$ & $\begin{array}{l}\text { States that did not } \\
\text { change TL/SC } \\
\text { policies } \\
\text { (5) }\end{array}$ & $\begin{array}{l}\text { Control for } \\
\text { SNAP policy } \\
\text { characteristics } \\
\text { (6) }\end{array}$ \\
\hline \multicolumn{7}{|c|}{ Years since policy influence (YPI) (reference: -2 to -1 year) } \\
\hline \multirow[t]{2}{*}{$0-1$ year $\times$ treat } & $-{ }^{-} 0.047 * * *$ & $-0.013 * * *$ & $-0.029 * * *$ & $-0.029 * *$ & -0.016 & $-0.036^{* * *}$ \\
\hline & $(0.009)$ & $(0.004)$ & $(0.008)$ & $(0.009)$ & $(0.010)$ & $(0.009)$ \\
\hline \multirow[t]{2}{*}{$2-3$ year $\times$ treat } & $-{ }^{-} 0.133^{* * *}$ & $-0.029 * * *$ & $-0.106 * * *$ & $-0.109 * * *$ & $-0.082 * * *$ & $-0.113^{* * *}$ \\
\hline & $(0.012)$ & $(0.005)$ & $(0.011)$ & $(0.011)$ & $(0.013)$ & $(0.011)$ \\
\hline \multirow[t]{2}{*}{$4-5$ year $\times$ treat } & $-0.153 * * *$ & $-0.015^{* *}$ & $-0.157 * * *$ & $-0.160 * * *$ & $-0.137 * * *$ & $-0.150 * * *$ \\
\hline & $(0.014)$ & $(0.005)$ & $(0.012)$ & $(0.013)$ & $(0.015)$ & $(0.013)$ \\
\hline \multirow[t]{2}{*}{$6-7$ year $\times$ treat } & $-0.184 * * *$ & $-0.018^{* *}$ & $-0.199 * * *$ & $-0.200 * * *$ & $-0.172 * * *$ & $-0.184 * * *$ \\
\hline & $(0.015)$ & $(0.006)$ & $(0.013)$ & $(0.013)$ & $(0.015)$ & $(0.015)$ \\
\hline \multirow[t]{2}{*}{$8-10$ year $\times$ treat } & $-{ }^{-} 0.173^{* * *}$ & $-0.016^{*}$ & $-0.194 * * *$ & $-0.194 * * *$ & $-0.166 * * *$ & $-0.177 * * *$ \\
\hline & $(0.016)$ & $(0.006)$ & $(0.014)$ & $(0.014)$ & $(0.016)$ & $(0.016)$ \\
\hline \multicolumn{7}{|l|}{ YPI $\times$ sanction } \\
\hline $0-1$ year $\times$ treat $\times$ full sanction & $\begin{array}{l}-0.050^{* *} \\
(0.016)\end{array}$ & $\begin{array}{l}0.006 \\
(0.006)\end{array}$ & $\begin{array}{l}-0.063 * * * \\
(0.015)\end{array}$ & $\begin{array}{l}-0.062 * * * \\
(0.016)\end{array}$ & $\begin{array}{l}-0.071 * * * \\
(0.016)\end{array}$ & $\begin{array}{l}-0.049 * * \\
(0.015)\end{array}$ \\
\hline $2-3$ year $\times$ treat $\times$ full sanction & $\begin{array}{l}-0.059 * * \\
(0.018)\end{array}$ & $\begin{array}{l}0.024 * * * \\
(0.007)\end{array}$ & $\begin{array}{l}-0.093 * * * \\
(0.017)\end{array}$ & $\begin{array}{l}-0.087 * * * \\
(0.017)\end{array}$ & $\begin{array}{l}-0.110 * * * \\
(0.018)\end{array}$ & $\begin{array}{l}-0.062 * * * \\
(0.017)\end{array}$ \\
\hline $4-5$ year $\times$ treat $\times$ full sanction & $\begin{array}{l}-0.015 \\
(0.025)\end{array}$ & $\begin{array}{l}0.015 \\
(0.010)\end{array}$ & $\begin{array}{l}-0.028 \\
(0.024)\end{array}$ & $\begin{array}{l}-0.024 \\
(0.025)\end{array}$ & $\begin{array}{l}-0.055^{*} \\
(0.025)\end{array}$ & $\begin{array}{l}-0.011 \\
(0.024)\end{array}$ \\
\hline $6-7$ year $\times$ treat $\times$ full sanction & $\begin{array}{l}-0.029 \\
(0.024)\end{array}$ & $\begin{array}{l}0.017^{+} \\
(0.009)\end{array}$ & $\begin{array}{l}-0.049 * \\
(0.022)\end{array}$ & $\begin{array}{l}-0.048^{*} \\
(0.023)\end{array}$ & $\begin{array}{l}-0.074 * * \\
(0.024)\end{array}$ & $\begin{array}{l}-0.033 \\
(0.023)\end{array}$ \\
\hline $8-10$ year $\times$ treat $\times$ full sanction & $\begin{array}{l}-0.029 \\
(0.026)\end{array}$ & $\begin{array}{l}0.011 \\
(0.010)\end{array}$ & $\begin{array}{l}-0.046^{+} \\
(0.024)\end{array}$ & $\begin{array}{l}-0.050^{*} \\
(0.025)\end{array}$ & $\begin{array}{l}-0.068 * * \\
(0.026)\end{array}$ & $\begin{array}{l}-0.027 \\
(0.024)\end{array}$ \\
\hline \multicolumn{7}{|l|}{ YPI $\times$ time limit } \\
\hline $0-1$ year $\times$ treat $x<60$ month & $\begin{array}{l}0.007^{\wedge} \\
(0.022)\end{array}$ & $\begin{array}{l}0.012 \\
(0.008)\end{array}$ & $\begin{array}{l}-0.003^{\wedge \wedge} \\
(0.021)\end{array}$ & $\begin{array}{l}-0.001^{\wedge \wedge} \\
(0.022)\end{array}$ & $\begin{array}{l}-0.034 \\
(0.023)\end{array}$ & $\begin{array}{l}-0.002^{\wedge} \\
(0.020)\end{array}$ \\
\hline $2-3$ year $\times<60$ month & $\begin{array}{l}- \\
0.093 * * * \\
(0.025)\end{array}$ & $\begin{array}{l}-0.002^{\wedge \wedge} \\
(0.009)\end{array}$ & $\begin{array}{l}-0.077 * * * \\
(0.023)\end{array}$ & $\begin{array}{l}-0.081 * * * \\
(0.024)\end{array}$ & $\begin{array}{l}-0.114 * * * \\
(0.025)\end{array}$ & $\begin{array}{l}-0.089 * * * \\
(0.023)\end{array}$ \\
\hline $4-5$ year $\times$ treat $x<60$ month & $\begin{array}{l}-0.058^{+} \\
(0.033)\end{array}$ & $\begin{array}{l}-0.016^{\wedge} \\
(0.013)\end{array}$ & $\begin{array}{l}-0.019 \\
(0.031)\end{array}$ & $\begin{array}{l}-0.020 \\
(0.032)\end{array}$ & $\begin{array}{l}-0.047 \\
(0.034)\end{array}$ & $\begin{array}{l}-0.041 \\
(0.031)\end{array}$ \\
\hline $6-7$ year $\times$ treat $\times<60$ month & $\begin{array}{l}-0.064^{*} \\
(0.032)\end{array}$ & $\begin{array}{l}-0.011^{\wedge} \\
(0.013)\end{array}$ & $\begin{array}{l}-0.027 \\
(0.030)\end{array}$ & $\begin{array}{l}-0.028 \\
(0.032)\end{array}$ & $\begin{array}{l}-0.062^{+} \\
(0.033)\end{array}$ & $\begin{array}{l}-0.048 \\
(0.030)\end{array}$ \\
\hline
\end{tabular}


Table 11 (continued)

\begin{tabular}{|c|c|c|c|c|c|c|}
\hline & \multicolumn{6}{|c|}{ TANF participation } \\
\hline & \multicolumn{2}{|c|}{ First-difference } & \multicolumn{4}{|l|}{ DDD } \\
\hline & $\begin{array}{l}\text { Treatment: } \\
\text { Single } \\
\text { mothers } \\
(1)\end{array}$ & $\begin{array}{l}\text { Comparison: } \\
\text { Married } \\
\text { mothers } \\
(2)\end{array}$ & $\begin{array}{l}\text { Women arrived } \\
\text { in the state } \\
\text { before } 1992 \\
\text { (3) }\end{array}$ & $\begin{array}{l}\text { Women } \\
\text { responded in all } \\
\text { survey years } \\
\text { (4) }\end{array}$ & $\begin{array}{l}\text { States that did not } \\
\text { change TL/SC } \\
\text { policies } \\
\text { (5) }\end{array}$ & $\begin{array}{l}\text { Control for } \\
\text { SNAP policy } \\
\text { characteristics } \\
\text { (6) }\end{array}$ \\
\hline $8-10$ year $\times$ treat $\times<60$ month & $\begin{array}{l}-0.099 * * \\
(0.036)\end{array}$ & $\begin{array}{l}-0.014 \\
(0.014)\end{array}$ & $\begin{array}{l}-0.057^{+} \\
(0.033)\end{array}$ & $\begin{array}{l}-0.054 \\
(0.034)\end{array}$ & $\begin{array}{l}-0.098^{* *} \\
(0.036)\end{array}$ & $\begin{array}{l}-0.078^{*} \\
(0.034)\end{array}$ \\
\hline Treat & - & - & $\begin{array}{l}-0.309 * * * \\
(0.086)\end{array}$ & $\begin{array}{l}-0.317 * * * \\
(0.088)\end{array}$ & $\begin{array}{l}-0.419 * * * \\
(0.105)\end{array}$ & $\begin{array}{l}-0.234 * * \\
(0.090)\end{array}$ \\
\hline Treat $\times$ full sanction & - & - & $\begin{array}{l}0.056^{* *} \\
(0.019)\end{array}$ & $\begin{array}{l}0.060 * * \\
(0.020)\end{array}$ & $\begin{array}{l}0.088 * * * \\
(0.020)\end{array}$ & $\begin{array}{l}0.043 * \\
(0.019)\end{array}$ \\
\hline Treat $\times<60$ month & - & - & $\begin{array}{l}0.004 \\
(0.025)\end{array}$ & $\begin{array}{l}0.005 \\
(0.027)\end{array}$ & $\begin{array}{l}0.043 \\
(0.027)\end{array}$ & $\begin{array}{l}0.033 \\
(0.024)\end{array}$ \\
\hline Constant & $\begin{array}{l}1.073 * \\
(0.478)\end{array}$ & $\begin{array}{l}0.240 \\
(0.172)\end{array}$ & $\begin{array}{l}0.715 * * * \\
(0.210)\end{array}$ & $\begin{array}{l}0.751 * * * \\
(0.213)\end{array}$ & $\begin{array}{l}0.485^{*} \\
(0.233)\end{array}$ & $\begin{array}{l}0.614 * * \\
(0.210)\end{array}$ \\
\hline \multicolumn{7}{|l|}{ Variance terms } \\
\hline State intercepts & 0.000 & 0.000 & 0.000 & 0.000 & 0.000 & 0.000 \\
\hline Ind. intercepts & 0.066 & 0.015 & 0.036 & 0.034 & 0.037 & 0.036 \\
\hline Residuals & 0.051 & 0.012 & 0.027 & 0.027 & 0.027 & 0.027 \\
\hline $\mathrm{N}$ & 14,528 & 23,618 & 37,036 & 35,544 & 30,027 & 38,146 \\
\hline
\end{tabular}

Each column is a separate linear multilevel regression model. All samples are restricted to U.S.-born women aged 18-45 at the time of TANF implementation in a given state, not having any college education, having lived in the current state of residence before 1996, and not having moved during the panel. Individual observations from years in which they were enrolled in school for more than one-third of the observed months in a year were excluded. Sample categorization (single mothers or married mothers) is based on the sample characteristics at time of TANF implementation, and the Treat variable indicates whether the respondent is a single mother (the reference group is married mothers). All models control for women's race [White (ref.), Black, Hispanic, and other race], age of the youngest child in the panel [0-2 (ref.), $>2$ to $<6,6$ to $<12,12$ to 18], and time-variant characteristics, including age in categories [18-24 (ref.), 25-29, 30-34, 35-39, 40-45, 45-49, 50-57], whether married, household size [1, 2, 3 or 4 (ref.), 5 or more], number of children [0,1, 2 (ref.), and 3 or more], unemployment rates in state $s$ and year $\mathrm{t}$, state EITC maximum benefits as a percentage of federal EITC in state $\mathrm{s}$ and year $\mathrm{t}$, a range of TANF state policy characteristics in state $\mathrm{s}$ and year $\mathrm{t}$ (e.g., maximum income eligibility for a family of three, maximum benefits for a family of three with no income, whether or not they have a family cap policy, age of a child (in months) until which a mother could be exempted from work requirements), years since policy influence (YPI) categories [ -2 to -1 (ref.), 0-1,2-3,4-5,6-7,8-10], interactions between YPI and full sanction or $<60$-month time limit variables, and state fixed effects. The reference group for TANF policy is states that did not implement full work sanction and did not have a time limit shorter than 60 months. Coefficients from Models (1) and (2) are from the first-difference models, so, different from the table label, the coefficients shown are those without the interactions with treatment status. Model (3) to Model (6) further control for treatment status, interactions between treatment and YPI categories, interactions between treatment and state policy variables, interactions between treatment and state unemployment rates, and three-way interactions between treatment, YPI categories, full sanction or $<60$-month time limit variables. Standard errors are in parentheses. In Model (3), samples are restricted to mothers who arrived in the state before 1992. In Model (4), samples are restricted to respondents who responded to all years of the SIPP survey. In Model (5), the samples are restricted states that did not change time limit or sanction policies during the study period. In Model (6), I include additional control of SNAP policy characteristics and treatment status' interaction with these characteristics ([1] whether the state requires fingerprinting of SNAP applicants; [2] the sum of federal, state, and grant outreach spending in nominal dollars (\$1000s); [3] regarding households with earnings, whether the state uses the simplified reporting option that reduces requirements for reporting changes in household circumstances; [4] whether the state exempts an amount higher than the SNAP standard auto exemption (set at \$4650 in FY2013) from the fair market value to determine the countable resource value of a vehicle; [5] whether the state disqualifies SNAP applicants or recipients who fail to perform actions required by other means-tested programs, primarily TANF; [6] the proportion of SNAP units with earnings with 13+ month recertification periods; [7] whether the state operates a combined application project for recipients of SSI, such that SSI recipients are able to use a streamlined SNAP application process; and [8] whether the state uses broad-based categorical eligibility to increase or eliminate the asset test and/or to increase the gross income limit for virtually all SNAP applicants; Economic Research Service [ERS], USDA 2017). The results from Wald tests examining whether coefficients from interactions between YPI X Full Sanction and YPI $\times<60$ month are the same at the particular YPI category are presented in the YPI $\times<60$ month rows $\left(\wedge^{\wedge}\right.$ indicates $0.1>\mathrm{p} \geq 0.05$ and ${ }^{\wedge} \wedge$ indicates $\mathrm{p}<0.05$ ). For example, if Wald tests reveal that the " $0-1$ year $\times$ full sanction" coefficient is different from the " $0-1$ year $\times<60$ month" coefficient, and the p-value is smaller than 0.05 , the " $0-1$ year $\times<60$ month" row will be marked as $\wedge \wedge$

${ }^{+} \mathrm{p}<0.10 . * \mathrm{p}<0.05 .{ }^{*} \mathrm{p}<0.01 . * * * \mathrm{p}<.001$ 
Table 12 First-difference results and sensitivity analyses-trajectories of SNAP participation and policy stringencies

\begin{tabular}{|c|c|c|c|c|c|c|}
\hline & \multicolumn{6}{|c|}{ SNAP participation } \\
\hline & \multicolumn{2}{|c|}{ First-difference } & \multicolumn{4}{|l|}{ DDD } \\
\hline & $\begin{array}{l}\text { Treatment: } \\
\text { Single } \\
\text { mothers } \\
(1)\end{array}$ & $\begin{array}{l}\text { Comparison: } \\
\text { Married } \\
\text { mothers } \\
(2)\end{array}$ & $\begin{array}{l}\text { Women arrived } \\
\text { in the state } \\
\text { before } 1992 \\
\text { (3) }\end{array}$ & $\begin{array}{l}\text { Women } \\
\text { responded in all } \\
\text { survey years } \\
\text { (4) }\end{array}$ & $\begin{array}{l}\text { States that did not } \\
\text { change TL/ SC } \\
\text { policies } \\
\text { (5) }\end{array}$ & $\begin{array}{l}\text { Control for } \\
\text { SNAP policy } \\
\text { characteristics } \\
\text { (6) }\end{array}$ \\
\hline \multicolumn{7}{|c|}{ Years since policy influence (YPI) (reference: -2 to -1 year) } \\
\hline $0-1$ year $\times$ treat & $\begin{array}{l}-0.056 * * * \\
(0.011)\end{array}$ & $\begin{array}{l}-0.015^{*} \\
(0.006)\end{array}$ & $\begin{array}{l}-0.035^{* *} \\
(0.012)\end{array}$ & $\begin{array}{l}-0.025^{*} \\
(0.012)\end{array}$ & $\begin{array}{l}-0.036^{*} \\
(0.014)\end{array}$ & $\begin{array}{l}-0.035^{* *} \\
(0.012)\end{array}$ \\
\hline $2-3$ year $\times$ treat & $\begin{array}{l}-0.128 * * * \\
(0.014)\end{array}$ & $\begin{array}{l}-0.030 * * * \\
(0.008)\end{array}$ & $\begin{array}{l}-0.098 * * * \\
(0.015)\end{array}$ & $\begin{array}{l}-0.092 * * * \\
(0.015)\end{array}$ & $\begin{array}{l}-0.110 * * * \\
(0.018)\end{array}$ & $\begin{array}{l}-0.100 * * * \\
(0.015)\end{array}$ \\
\hline $4-5$ year $\times$ treat & $\begin{array}{l}-0.090^{* * *} \\
(0.017)\end{array}$ & $\begin{array}{l}-0.005 \\
(0.009)\end{array}$ & $\begin{array}{l}-0.097 * * * \\
(0.017)\end{array}$ & $\begin{array}{l}-0.093^{* * * *} \\
(0.018)\end{array}$ & $\begin{array}{l}-0.114 * * * \\
(0.021)\end{array}$ & $\begin{array}{l}-0.095^{* * *} \\
(0.018)\end{array}$ \\
\hline $6-7$ year $\times$ treat & $\begin{array}{l}-0.081^{* * *} \\
(0.019)\end{array}$ & $\begin{array}{l}-0.003 \\
(0.010)\end{array}$ & $\begin{array}{l}-0.096^{* * *} \\
(0.018)\end{array}$ & $\begin{array}{l}-0.095^{* * *} \\
(0.019)\end{array}$ & $\begin{array}{l}-0.115^{* * *} \\
(0.021)\end{array}$ & $\begin{array}{l}-0.100 * * * \\
(0.021)\end{array}$ \\
\hline $8-10$ year $\times$ treat & $\begin{array}{l}-0.038^{+} \\
(0.020)\end{array}$ & $\begin{array}{l}0.022^{+} \\
(0.011)\end{array}$ & $\begin{array}{l}-0.078 * * * \\
(0.019)\end{array}$ & $\begin{array}{l}-0.077 * * * \\
(0.020)\end{array}$ & $\begin{array}{l}-0.086^{* * *} \\
(0.023)\end{array}$ & $\begin{array}{l}-0.089 * * * \\
(0.023)\end{array}$ \\
\hline \multicolumn{7}{|l|}{ YPI $\times$ sanction } \\
\hline $0-1$ year $\times$ treat $\times$ full sanction & $\begin{array}{l}-0.017 \\
(0.019)\end{array}$ & $\begin{array}{l}-0.004 \\
(0.011)\end{array}$ & $\begin{array}{l}-0.013 \\
(0.021)\end{array}$ & $\begin{array}{l}-0.017 \\
(0.022)\end{array}$ & $\begin{array}{l}-0.013 \\
(0.022)\end{array}$ & $\begin{array}{l}-0.012 \\
(0.021)\end{array}$ \\
\hline $2-3$ year $\times$ treat $\times$ full sanction & $\begin{array}{l}-0.030 \\
(0.022)\end{array}$ & $\begin{array}{l}-0.001 \\
(0.012)\end{array}$ & $\begin{array}{l}-0.021 \\
(0.023)\end{array}$ & $\begin{array}{l}-0.017 \\
(0.024)\end{array}$ & $\begin{array}{l}-0.004 \\
(0.024)\end{array}$ & $\begin{array}{l}-0.011 \\
(0.024)\end{array}$ \\
\hline $4-5$ year $\times$ treat $\times$ full sanction & $\begin{array}{l}0.037 \\
(0.031)\end{array}$ & $\begin{array}{l}-0.002 \\
(0.018)\end{array}$ & $\begin{array}{l}0.044 \\
(0.034)\end{array}$ & $\begin{array}{l}0.065^{+} \\
(0.035)\end{array}$ & $\begin{array}{l}0.051 \\
(0.035)\end{array}$ & $\begin{array}{l}0.048 \\
(0.034)\end{array}$ \\
\hline $6-7$ year $\times$ treat $\times$ full sanction & $\begin{array}{l}0.023 \\
(0.030)\end{array}$ & $\begin{array}{l}0.015 \\
(0.017)\end{array}$ & $\begin{array}{l}0.011 \\
(0.032)\end{array}$ & $\begin{array}{l}0.028 \\
(0.034)\end{array}$ & $\begin{array}{l}0.018 \\
(0.034)\end{array}$ & $\begin{array}{l}0.020 \\
(0.033)\end{array}$ \\
\hline $8-10$ year $\times$ treat $\times$ full sanction & $\begin{array}{l}0.017 \\
(0.032)\end{array}$ & $\begin{array}{l}0.004 \\
(0.018)\end{array}$ & $\begin{array}{l}0.012 \\
(0.035)\end{array}$ & $\begin{array}{l}0.024 \\
(0.036)\end{array}$ & $\begin{array}{l}0.008 \\
(0.036)\end{array}$ & $\begin{array}{l}0.020 \\
(0.035)\end{array}$ \\
\hline \multicolumn{7}{|l|}{ YPI $\times$ time limit } \\
\hline $0-1$ year $\times$ treat $\times<60$ month & $\begin{array}{l}-0.026 \\
(0.026)\end{array}$ & $\begin{array}{l}0.027^{+\wedge} \\
(0.015)\end{array}$ & $\begin{array}{l}-0.060 * \\
(0.028)\end{array}$ & $\begin{array}{l}-0.064^{*} \\
(0.031)\end{array}$ & $\begin{array}{l}-0.051^{+} \\
(0.030)\end{array}$ & $\begin{array}{l}-0.053 \mathrm{v} \\
(0.028)\end{array}$ \\
\hline $2-3$ year $\times<60$ month & $\begin{array}{l}- \\
0.101 * * * \wedge \\
(0.030)\end{array}$ & $\begin{array}{l}0.010 \\
(0.016)\end{array}$ & $\begin{array}{l}-0.113^{* * * \wedge \wedge} \\
(0.031)\end{array}$ & $\begin{array}{l}-0.120 * * * \wedge \wedge \\
(0.032)\end{array}$ & $\begin{array}{l}-0.113^{* * * \wedge \wedge} \\
(0.033)\end{array}$ & $\begin{array}{l}-0.112^{* * * \wedge \wedge} \\
(0.031)\end{array}$ \\
\hline $4-5$ year $\times$ treat $\times<60$ month & $\begin{array}{l}-0.058^{\wedge} \\
(0.041)\end{array}$ & $\begin{array}{l}0.038^{+} \\
(0.023)\end{array}$ & $\begin{array}{l}-0.084^{+\wedge \wedge} \\
(0.044)\end{array}$ & $\begin{array}{l}-0.091^{* \wedge \wedge} \\
(0.046)\end{array}$ & $\begin{array}{l}-0.098^{* \wedge \wedge} \\
(0.047)\end{array}$ & $\begin{array}{l}-0.089^{* \wedge \wedge} \\
(0.043)\end{array}$ \\
\hline $6-7$ year $\times$ treat $\times<60$ month & $\begin{array}{l}-0.101^{* \wedge \wedge} \\
(0.041)\end{array}$ & $\begin{array}{l}0.017 \\
(0.022)\end{array}$ & $\begin{array}{l}-0.119^{* * \wedge \wedge} \\
(0.043)\end{array}$ & $\begin{array}{l}-0.112^{* \wedge \wedge} \\
(0.045)\end{array}$ & $\begin{array}{l}-0.117^{* \wedge \wedge} \\
(0.046)\end{array}$ & $\begin{array}{l}-0.108^{* \wedge \wedge} \\
(0.043)\end{array}$ \\
\hline $8-10$ year $\times$ treat $\times<60$ month & $\begin{array}{l}- \\
0.122^{* * \wedge \wedge} \\
(0.045)\end{array}$ & $\begin{array}{l}0.026 \\
(0.025)\end{array}$ & $\begin{array}{l}-0.140^{* * \wedge \wedge} \\
(0.048)\end{array}$ & $\begin{array}{l}-0.153^{* * \wedge \wedge} \\
(0.050)\end{array}$ & $\begin{array}{l}-0.140^{* * \wedge \wedge} \\
(0.051)\end{array}$ & $\begin{array}{l}-0.147^{* * \wedge \wedge} \\
(0.048)\end{array}$ \\
\hline Treat & - & - & $\begin{array}{l}0.231^{+} \\
(0.127)\end{array}$ & $\begin{array}{l}0.188 \\
(0.131)\end{array}$ & $\begin{array}{l}0.382 * \\
(0.152)\end{array}$ & $\begin{array}{l}0.280 * \\
(0.132)\end{array}$ \\
\hline Treat $\times$ full sanction & - & - & $\begin{array}{l}0.004 \\
(0.027)\end{array}$ & $\begin{array}{l}-0.008 \\
(0.029)\end{array}$ & $\begin{array}{l}-0.016 \\
(0.029)\end{array}$ & $\begin{array}{l}-0.006 \\
(0.027)\end{array}$ \\
\hline Treat $\times<60$ month & - & - & $\begin{array}{l}0.074 * \\
(0.035)\end{array}$ & $\begin{array}{l}0.089 * \\
(0.039)\end{array}$ & $\begin{array}{l}0.086^{*} \\
(0.038)\end{array}$ & $\begin{array}{l}0.079 * \\
(0.035)\end{array}$ \\
\hline Constant & $\begin{array}{l}1.050^{+} \\
(0.591)\end{array}$ & $\begin{array}{l}0.833 * * \\
(0.305)\end{array}$ & $\begin{array}{l}0.829 * * \\
(0.297)\end{array}$ & $\begin{array}{l}0.905 * * \\
(0.302)\end{array}$ & $\begin{array}{l}0.862 * * \\
(0.323)\end{array}$ & $\begin{array}{l}0.874 * * \\
(0.296)\end{array}$ \\
\hline Variance terms & & & & & & \\
\hline
\end{tabular}


Table 12 (continued)

\begin{tabular}{|c|c|c|c|c|c|c|}
\hline & \multicolumn{6}{|c|}{ SNAP participation } \\
\hline & \multicolumn{2}{|c|}{ First-difference } & \multicolumn{4}{|l|}{ DDD } \\
\hline & $\begin{array}{l}\text { Treatment: } \\
\text { Single } \\
\text { mothers } \\
(1)\end{array}$ & $\begin{array}{l}\text { Comparison: } \\
\text { Married } \\
\text { mothers } \\
(2)\end{array}$ & $\begin{array}{l}\text { Women arrived } \\
\text { in the state } \\
\text { before } 1992 \\
\text { (3) }\end{array}$ & $\begin{array}{l}\text { Women } \\
\text { responded in all } \\
\text { survey years } \\
\text { (4) }\end{array}$ & $\begin{array}{l}\text { States that did not } \\
\text { change TL/ SC } \\
\text { policies } \\
\text { (5) }\end{array}$ & $\begin{array}{l}\text { Control for } \\
\text { SNAP policy } \\
\text { characteristics } \\
\text { (6) }\end{array}$ \\
\hline State intercepts & 0.000 & 0.000 & 0.000 & 0.000 & 0.000 & 0.000 \\
\hline Ind. intercepts & 0.122 & 0.055 & 0.083 & 0.082 & 0.084 & 0.083 \\
\hline Residuals & 0.073 & 0.037 & 0.050 & 0.050 & 0.049 & 0.050 \\
\hline $\mathrm{N}$ & 14,528 & 23,618 & 37,036 & 35,544 & 30,027 & 38,146 \\
\hline
\end{tabular}

Each column is a separate linear multilevel regression model. See Appendix Table 11 for sample and model specifications. Standard errors are in parentheses. Coefficients from Models (1) and (2) are from the first-difference models, so, different from the table label, the coefficients shown are those without the interactions with treatment status

${ }^{+} \mathrm{p}<0.10 . * \mathrm{p}<0.05 . * * \mathrm{p}<0.01 . * * * \mathrm{p}<.001$

Table 13 First-difference results and sensitivity analyses - trajectories of SSI participation and policy stringencies

\begin{tabular}{|c|c|c|c|c|c|c|}
\hline & \multicolumn{6}{|c|}{ SSI participation } \\
\hline & \multicolumn{2}{|c|}{ First-difference } & \multicolumn{4}{|l|}{ DDD } \\
\hline & $\begin{array}{l}\text { Treatment: } \\
\text { Single } \\
\text { mothers } \\
(1)\end{array}$ & $\begin{array}{l}\text { Comparison: } \\
\text { Married } \\
\text { mothers } \\
(2)\end{array}$ & $\begin{array}{l}\text { Women arrived } \\
\text { in the state } \\
\text { before } 1992 \\
\text { (3) }\end{array}$ & $\begin{array}{l}\text { Women } \\
\text { responded in all } \\
\text { survey years } \\
\text { (4) }\end{array}$ & $\begin{array}{l}\text { States that did not } \\
\text { change TL/SC } \\
\text { policies } \\
\text { (5) }\end{array}$ & $\begin{array}{l}\text { Control for } \\
\text { SNAP policy } \\
\text { characteristics } \\
\text { (6) }\end{array}$ \\
\hline \multicolumn{7}{|c|}{ Years since policy influence (YPI) (reference: -2 to -1 year) } \\
\hline $0-1$ year $\times$ treat & $\begin{array}{l}0.006 \\
(0.007)\end{array}$ & $\begin{array}{l}0.000 \\
(0.003)\end{array}$ & $\begin{array}{l}0.007 \\
(0.007)\end{array}$ & $\begin{array}{l}0.012^{+} \\
(0.007)\end{array}$ & $\begin{array}{l}0.007 \\
(0.008)\end{array}$ & $\begin{array}{l}0.009 \\
(0.007)\end{array}$ \\
\hline $2-3$ year $\times$ treat & $\begin{array}{l}-0.002 \\
(0.009)\end{array}$ & $\begin{array}{l}0.004 \\
(0.004)\end{array}$ & $\begin{array}{l}-0.002 \\
(0.008)\end{array}$ & $\begin{array}{l}0.002 \\
(0.009)\end{array}$ & $\begin{array}{l}0.003 \\
(0.010)\end{array}$ & $\begin{array}{l}-0.000 \\
(0.008)\end{array}$ \\
\hline $4-5$ year $\times$ treat & $\begin{array}{l}0.013 \\
(0.011)\end{array}$ & $\begin{array}{l}0.010 * \\
(0.005)\end{array}$ & $\begin{array}{l}0.008 \\
(0.010)\end{array}$ & $\begin{array}{l}0.011 \\
(0.011)\end{array}$ & $\begin{array}{l}0.009 \\
(0.012)\end{array}$ & $\begin{array}{l}0.014 \\
(0.011)\end{array}$ \\
\hline $6-7$ year $\times$ treat & $\begin{array}{l}0.010 \\
(0.012)\end{array}$ & $\begin{array}{l}0.018 * * \\
(0.006)\end{array}$ & $\begin{array}{l}0.001 \\
(0.011)\end{array}$ & $\begin{array}{l}0.005 \\
(0.012)\end{array}$ & $\begin{array}{l}0.001 \\
(0.013)\end{array}$ & $\begin{array}{l}0.004 \\
(0.013)\end{array}$ \\
\hline $8-10$ year $\times$ treat & $\begin{array}{l}0.020 \\
(0.013)\end{array}$ & $\begin{array}{l}0.015^{*} \\
(0.006)\end{array}$ & $\begin{array}{l}0.021^{+} \\
(0.012)\end{array}$ & $\begin{array}{l}0.023^{+} \\
(0.012)\end{array}$ & $\begin{array}{l}0.019 \\
(0.014)\end{array}$ & $\begin{array}{l}0.019 \\
(0.014)\end{array}$ \\
\hline \multicolumn{7}{|l|}{ YPI $\times$ sanction } \\
\hline $0-1$ year $\times$ treat $\times$ full sanction & $\begin{array}{l}-0.002 \\
(0.012)\end{array}$ & $\begin{array}{l}0.009^{+} \\
(0.006)\end{array}$ & $\begin{array}{l}-0.010 \\
(0.012)\end{array}$ & $\begin{array}{l}-0.009 \\
(0.012)\end{array}$ & $\begin{array}{l}-0.009 \\
(0.012)\end{array}$ & $\begin{array}{l}-0.015 \\
(0.012)\end{array}$ \\
\hline $2-3$ year $\times$ treat $\times$ full sanction & $\begin{array}{l}-0.001 \\
(0.013)\end{array}$ & $\begin{array}{l}0.015^{*} \\
(0.006)\end{array}$ & $\begin{array}{l}-0.017 \\
(0.013)\end{array}$ & $\begin{array}{l}-0.015 \\
(0.013)\end{array}$ & $\begin{array}{l}-0.016 \\
(0.014)\end{array}$ & $\begin{array}{l}-0.015 \\
(0.014)\end{array}$ \\
\hline $4-5$ year $\times$ treat $\times$ full sanction & $\begin{array}{l}-0.022 \\
(0.021)\end{array}$ & $\begin{array}{l}0.020^{+} \\
(0.010)\end{array}$ & $\begin{array}{l}-0.039^{+} \\
(0.021)\end{array}$ & $\begin{array}{l}-0.031 \\
(0.022)\end{array}$ & $\begin{array}{l}-0.036 \\
(0.022)\end{array}$ & $\begin{array}{l}-0.043^{*} \\
(0.021)\end{array}$ \\
\hline $6-7$ year $\times$ treat $\times$ full sanction & $\begin{array}{l}-0.008 \\
(0.020)\end{array}$ & $\begin{array}{l}0.000 \\
(0.010)\end{array}$ & $\begin{array}{l}-0.008 \\
(0.021)\end{array}$ & $\begin{array}{l}-0.000 \\
(0.022)\end{array}$ & $\begin{array}{l}-0.005 \\
(0.022)\end{array}$ & $\begin{array}{l}-0.008 \\
(0.021)\end{array}$ \\
\hline $8-10$ year $\times$ treat $\times$ full sanction & $\begin{array}{l}-0.026 \\
(0.022)\end{array}$ & $\begin{array}{l}-0.005 \\
(0.011)\end{array}$ & $\begin{array}{l}-0.022 \\
(0.022)\end{array}$ & $\begin{array}{l}-0.011 \\
(0.023)\end{array}$ & $\begin{array}{l}-0.018 \\
(0.024)\end{array}$ & $\begin{array}{l}-0.020 \\
(0.022)\end{array}$ \\
\hline \multicolumn{7}{|l|}{ YPI $\times$ time limit } \\
\hline $0-1$ year $\times$ treat $\times<60$ month & $\begin{array}{l}-0.003 \\
(0.016)\end{array}$ & $\begin{array}{l}0.010 \\
(0.008)\end{array}$ & $\begin{array}{l}-0.014 \\
(0.016)\end{array}$ & $\begin{array}{l}0.007 \\
(0.017)\end{array}$ & $\begin{array}{l}-0.034^{+} \\
(0.017)\end{array}$ & $\begin{array}{l}-0.011 \\
(0.016)\end{array}$ \\
\hline $2-3$ year $\times<60$ month & $\begin{array}{l}-0.028 \\
(0.018)\end{array}$ & $\begin{array}{l}-0.001 \\
(0.009)\end{array}$ & $\begin{array}{l}-0.025 \\
(0.018)\end{array}$ & $\begin{array}{l}-0.012 \\
(0.018)\end{array}$ & $\begin{array}{l}-0.043^{*} \\
(0.019)\end{array}$ & $\begin{array}{l}-0.025 \\
(0.018)\end{array}$ \\
\hline
\end{tabular}


Table 13 (continued)

\begin{tabular}{|c|c|c|c|c|c|c|}
\hline & \multicolumn{6}{|c|}{ SSI participation } \\
\hline & \multicolumn{2}{|c|}{ First-difference } & \multicolumn{4}{|l|}{ DDD } \\
\hline & $\begin{array}{l}\text { Treatment: } \\
\text { Single } \\
\text { mothers } \\
(1)\end{array}$ & $\begin{array}{l}\text { Comparison: } \\
\text { Married } \\
\text { mothers } \\
(2)\end{array}$ & $\begin{array}{l}\text { Women arrived } \\
\text { in the state } \\
\text { before } 1992 \\
\text { (3) }\end{array}$ & $\begin{array}{l}\text { Women } \\
\text { responded in all } \\
\text { survey years } \\
\text { (4) }\end{array}$ & $\begin{array}{l}\text { States that did not } \\
\text { change TL/SC } \\
\text { policies } \\
\text { (5) }\end{array}$ & $\begin{array}{l}\text { Control for } \\
\text { SNAP policy } \\
\text { characteristics } \\
\text { (6) }\end{array}$ \\
\hline $4-5$ year $\times$ treat $x<60$ month & $\begin{array}{l}-0.029 \\
(0.027)\end{array}$ & $\begin{array}{l}0.003 \\
(0.013)\end{array}$ & $\begin{array}{l}-0.021 \\
(0.027)\end{array}$ & $\begin{array}{l}-0.005 \\
(0.028)\end{array}$ & $\begin{array}{l}-0.028 \\
(0.029)\end{array}$ & $\begin{array}{l}-0.026 \\
(0.027)\end{array}$ \\
\hline $6-7$ year $\times$ treat $x<60$ month & $\begin{array}{l}-0.045^{+} \\
(0.027)\end{array}$ & $\begin{array}{l}0.003 \\
(0.013)\end{array}$ & $\begin{array}{l}-0.031 \\
(0.027)\end{array}$ & $\begin{array}{l}-0.022 \\
(0.028)\end{array}$ & $\begin{array}{l}-0.050^{+} \\
(0.029)\end{array}$ & $\begin{array}{l}-0.037 \\
(0.027)\end{array}$ \\
\hline $8-10$ year $\times$ treat $\times<60$ month & $\begin{array}{l}-0.018 \\
(0.030)\end{array}$ & $\begin{array}{l}0.008 \\
(0.014)\end{array}$ & $\begin{array}{l}-0.007 \\
(0.030)\end{array}$ & $\begin{array}{l}0.000 \\
(0.031)\end{array}$ & $\begin{array}{l}-0.012 \\
(0.033)\end{array}$ & $\begin{array}{l}-0.029 \\
(0.030)\end{array}$ \\
\hline Treat & - & - & $\begin{array}{l}0.059 \\
(0.089)\end{array}$ & $\begin{array}{l}0.058 \\
(0.092)\end{array}$ & $\begin{array}{l}0.202^{+} \\
(0.108)\end{array}$ & $\begin{array}{l}0.038 \\
(0.091)\end{array}$ \\
\hline Treat $\times$ full sanction & - & - & $\begin{array}{l}0.033^{+} \\
(0.018)\end{array}$ & $\begin{array}{l}0.029 \\
(0.019)\end{array}$ & $\begin{array}{l}0.013 \\
(0.020)\end{array}$ & $\begin{array}{l}0.020 \\
(0.018)\end{array}$ \\
\hline Treat $\times<60$ month & - & - & $\begin{array}{l}0.041^{+} \\
(0.023)\end{array}$ & $\begin{array}{l}0.032 \\
(0.025)\end{array}$ & $\begin{array}{l}0.058^{*} \\
(0.025)\end{array}$ & $\begin{array}{l}0.049 * \\
(0.023)\end{array}$ \\
\hline Constant & $\begin{array}{l}0.430 \\
(0.379)\end{array}$ & $\begin{array}{l}-0.111 \\
(0.169)\end{array}$ & $\begin{array}{l}0.045 \\
(0.180)\end{array}$ & $\begin{array}{l}0.033 \\
(0.181)\end{array}$ & $\begin{array}{l}-0.094 \\
(0.197)\end{array}$ & $\begin{array}{l}0.019 \\
(0.178)\end{array}$ \\
\hline \multicolumn{7}{|l|}{ Variance terms } \\
\hline State intercepts & 0.000 & 0.000 & 0.000 & 0.000 & 0.000 & 0.000 \\
\hline Ind. intercepts & 0.079 & 0.027 & 0.048 & 0.047 & 0.048 & 0.047 \\
\hline Residuals & 0.026 & 0.010 & 0.016 & 0.016 & 0.016 & 0.016 \\
\hline $\mathrm{N}$ & 14,528 & 23,618 & 37,036 & 35,544 & 30,027 & 38,146 \\
\hline
\end{tabular}

Each column is a separate linear multilevel regression model. See Appendix Table 11 for sample and model specifications. Standard errors are in parentheses. Coefficients from Model (1) and (2) are from the first-difference models, so, different from the table label, the coefficients shown are those without the interactions with treatment status

${ }^{+} \mathrm{p}<0.10 . * \mathrm{p}<0.05 . * * \mathrm{p}<0.01 . * * * \mathrm{p}<.001$

Table 14 First-difference results and sensitivity analyses-trajectories of employment and policy stringencies

\begin{tabular}{|c|c|c|c|c|c|c|}
\hline & \multicolumn{6}{|c|}{ Employment } \\
\hline & \multicolumn{2}{|c|}{ First-difference } & \multicolumn{4}{|l|}{ DDD } \\
\hline & $\begin{array}{l}\text { Treatment: } \\
\text { Single } \\
\text { mothers } \\
\text { (1) }\end{array}$ & $\begin{array}{l}\text { Comparison: } \\
\text { Married } \\
\text { mothers } \\
(2)\end{array}$ & $\begin{array}{l}\text { Women arrived } \\
\text { in the state } \\
\text { before } 1992 \\
\text { (3) }\end{array}$ & $\begin{array}{l}\text { Women } \\
\text { responded in all } \\
\text { survey years } \\
\text { (4) }\end{array}$ & $\begin{array}{l}\text { States that did not } \\
\text { change TL/ SC } \\
\text { policies } \\
\text { (5) }\end{array}$ & $\begin{array}{l}\text { Control for } \\
\text { SNAP policy } \\
\text { characteristics } \\
\text { (6) }\end{array}$ \\
\hline \multicolumn{7}{|c|}{ Years since policy influence (YPI) (reference: -2 to -1 year) } \\
\hline $0-1$ year $\times$ treat & $\begin{array}{l}0.073 * * * \\
(0.012)\end{array}$ & $\begin{array}{l}0.039 * * * \\
(0.009)\end{array}$ & $\begin{array}{l}0.033 * \\
(0.015)\end{array}$ & $\begin{array}{l}0.038 * \\
(0.015)\end{array}$ & $\begin{array}{l}0.037 * \\
(0.018)\end{array}$ & $\begin{array}{l}0.029 * \\
(0.015)\end{array}$ \\
\hline $2-3$ year $\times$ treat & $\begin{array}{l}0.090 * * * \\
(0.016)\end{array}$ & $\begin{array}{l}0.055 * * * \\
(0.011)\end{array}$ & $\begin{array}{l}0.038 * \\
(0.018)\end{array}$ & $\begin{array}{l}0.041 * \\
(0.019)\end{array}$ & $\begin{array}{l}0.028 \\
(0.022)\end{array}$ & $\begin{array}{l}0.034^{+} \\
(0.018)\end{array}$ \\
\hline $4-5$ year $\times$ treat & $\begin{array}{l}0.113 * * * \\
(0.018)\end{array}$ & $\begin{array}{l}0.048 * * * \\
(0.013)\end{array}$ & $\begin{array}{l}0.058 * * \\
(0.022)\end{array}$ & $\begin{array}{l}0.057 * \\
(0.022)\end{array}$ & $\begin{array}{l}0.032 \\
(0.026)\end{array}$ & $\begin{array}{l}0.054 * \\
(0.023)\end{array}$ \\
\hline $6-7$ year $\times$ treat & $\begin{array}{l}0.093 * * * \\
(0.020)\end{array}$ & $\begin{array}{l}0.040 \text { ** } \\
(0.015)\end{array}$ & $\begin{array}{l}0.038^{+} \\
(0.023)\end{array}$ & $\begin{array}{l}0.036 \\
(0.023)\end{array}$ & $\begin{array}{l}0.012 \\
(0.027)\end{array}$ & $\begin{array}{l}0.036 \\
(0.026)\end{array}$ \\
\hline
\end{tabular}


Table 14 (continued)

\begin{tabular}{|c|c|c|c|c|c|c|}
\hline & \multicolumn{6}{|l|}{ Employment } \\
\hline & \multicolumn{2}{|c|}{ First-difference } & \multicolumn{4}{|l|}{ DDD } \\
\hline & $\begin{array}{l}\text { Treatment: } \\
\text { Single } \\
\text { mothers } \\
\text { (1) }\end{array}$ & $\begin{array}{l}\text { Comparison: } \\
\text { Married } \\
\text { mothers } \\
(2)\end{array}$ & $\begin{array}{l}\text { Women arrived } \\
\text { in the state } \\
\text { before } 1992 \\
\text { (3) }\end{array}$ & $\begin{array}{l}\text { Women } \\
\text { responded in all } \\
\text { survey years } \\
\text { (4) }\end{array}$ & $\begin{array}{l}\text { States that did not } \\
\text { change TL/ SC } \\
\text { policies } \\
\text { (5) }\end{array}$ & $\begin{array}{l}\text { Control for } \\
\text { SNAP policy } \\
\text { characteristics } \\
\text { (6) }\end{array}$ \\
\hline $8-10$ year $\times$ treat & $\begin{array}{l}0.088 * * * \\
(0.022)\end{array}$ & $\begin{array}{l}0.031^{+} \\
(0.016)\end{array}$ & $\begin{array}{l}0.042^{+} \\
(0.024)\end{array}$ & $\begin{array}{l}0.046^{+} \\
(0.025)\end{array}$ & $\begin{array}{l}0.029 \\
(0.029)\end{array}$ & $\begin{array}{l}0.040 \\
(0.028)\end{array}$ \\
\hline \multicolumn{7}{|l|}{ YPI $\times$ sanction } \\
\hline $0-1$ year $\times$ treat $\times$ full sanction & $\begin{array}{l}0.025 \\
(0.021)\end{array}$ & $\begin{array}{l}-0.001 \\
(0.015)\end{array}$ & $\begin{array}{l}0.031 \\
(0.026)\end{array}$ & $\begin{array}{l}0.018 \\
(0.028)\end{array}$ & $\begin{array}{l}0.027 \\
(0.027)\end{array}$ & $\begin{array}{l}0.019 \\
(0.026)\end{array}$ \\
\hline $2-3$ year $\times$ treat $\times$ full sanction & $\begin{array}{l}0.005 \\
(0.024)\end{array}$ & $\begin{array}{l}-0.009 \\
(0.017)\end{array}$ & $\begin{array}{l}0.016 \\
(0.029)\end{array}$ & $\begin{array}{l}0.009 \\
(0.029)\end{array}$ & $\begin{array}{l}0.029 \\
(0.030)\end{array}$ & $\begin{array}{l}-0.010 \\
(0.030)\end{array}$ \\
\hline 4-5 year $\times$ treat $\times$ full sanction & $\begin{array}{l}-0.031 \\
(0.033)\end{array}$ & $\begin{array}{l}-0.003 \\
(0.026)\end{array}$ & $\begin{array}{l}-0.036 \\
(0.042)\end{array}$ & $\begin{array}{l}-0.037 \\
(0.044)\end{array}$ & $\begin{array}{l}-0.010 \\
(0.044)\end{array}$ & $\begin{array}{l}-0.056 \\
(0.042)\end{array}$ \\
\hline $6-7$ year $\times$ treat $\times$ full sanction & $\begin{array}{l}-0.001 \\
(0.032)\end{array}$ & $\begin{array}{l}-0.014 \\
(0.025)\end{array}$ & $\begin{array}{l}0.005 \\
(0.040)\end{array}$ & $\begin{array}{l}0.012 \\
(0.042)\end{array}$ & $\begin{array}{l}0.026 \\
(0.042)\end{array}$ & $\begin{array}{l}-0.010 \\
(0.040)\end{array}$ \\
\hline $8-10$ year $\times$ treat $\times$ full sanction & $\begin{array}{l}0.015 \\
(0.034)\end{array}$ & $\begin{array}{l}0.017 \\
(0.027)\end{array}$ & $\begin{array}{l}-0.005 \\
(0.043)\end{array}$ & $\begin{array}{l}-0.009 \\
(0.045)\end{array}$ & $\begin{array}{l}-0.001 \\
(0.045)\end{array}$ & $\begin{array}{l}-0.024 \\
(0.043)\end{array}$ \\
\hline \multicolumn{7}{|l|}{ YPI $\times$ time limit } \\
\hline $0-1$ year $\times$ treat $\times<60$ month & $\begin{array}{l}-0.016 \\
(0.029)\end{array}$ & $\begin{array}{l}-0.018 \\
(0.021)\end{array}$ & $\begin{array}{l}-0.005 \\
(0.035)\end{array}$ & $\begin{array}{l}-0.025 \\
(0.038)\end{array}$ & $\begin{array}{l}0.004 \\
(0.038)\end{array}$ & $\begin{array}{l}0.004 \\
(0.035)\end{array}$ \\
\hline $2-3$ year $\times<60$ month & $\begin{array}{l}0.007 \\
(0.033)\end{array}$ & $\begin{array}{l}-0.051 * \\
(0.023)\end{array}$ & $\begin{array}{l}0.026 \\
(0.039)\end{array}$ & $\begin{array}{l}0.022 \\
(0.040)\end{array}$ & $\begin{array}{l}0.065 \\
(0.042)\end{array}$ & $\begin{array}{l}0.047 \\
(0.039)\end{array}$ \\
\hline 4-5 year $\times$ treat $\times<60$ month & $\begin{array}{l}-0.003 \\
(0.044)\end{array}$ & $\begin{array}{l}-0.070 * \\
(0.033)\end{array}$ & $\begin{array}{l}0.045 \\
(0.055)\end{array}$ & $\begin{array}{l}0.018 \\
(0.057)\end{array}$ & $\begin{array}{l}0.059 \\
(0.059)\end{array}$ & $\begin{array}{l}0.052 \\
(0.054)\end{array}$ \\
\hline 6-7 year $\times$ treat $\times<60$ month & $\begin{array}{l}-0.020 \\
(0.043)\end{array}$ & $\begin{array}{l}-0.005 \\
(0.033)\end{array}$ & $\begin{array}{l}-0.045 \\
(0.054)\end{array}$ & $\begin{array}{l}-0.073 \\
(0.056)\end{array}$ & $\begin{array}{l}-0.028 \\
(0.058)\end{array}$ & $\begin{array}{l}-0.030 \\
(0.054)\end{array}$ \\
\hline $8-10$ year $\times$ treat $\times<60$ month & $\begin{array}{l}-0.025 \\
(0.047)\end{array}$ & $\begin{array}{l}-0.020 \\
(0.036)\end{array}$ & $\begin{array}{l}-0.039 \\
(0.059)\end{array}$ & $\begin{array}{l}-0.071 \\
(0.061)\end{array}$ & $\begin{array}{l}-0.028 \\
(0.063)\end{array}$ & $\begin{array}{l}-0.033 \\
(0.059)\end{array}$ \\
\hline Treat & - & - & $\begin{array}{l}-0.116 \\
(0.156)\end{array}$ & $\begin{array}{l}-0.140 \\
(0.161)\end{array}$ & $\begin{array}{l}-0.020 \\
(0.188)\end{array}$ & $\begin{array}{l}-0.051 \\
(0.162)\end{array}$ \\
\hline Treat $\times$ full sanction & - & - & $\begin{array}{l}-0.043 \\
(0.033)\end{array}$ & $\begin{array}{l}-0.052 \\
(0.036)\end{array}$ & $\begin{array}{l}-0.051 \\
(0.036)\end{array}$ & $\begin{array}{l}-0.030 \\
(0.034)\end{array}$ \\
\hline Treat $\times<60$ month & - & - & $\begin{array}{l}0.015 \\
(0.044)\end{array}$ & $\begin{array}{l}0.051 \\
(0.048)\end{array}$ & $\begin{array}{l}-0.003 \\
(0.047)\end{array}$ & $\begin{array}{l}0.012 \\
(0.043)\end{array}$ \\
\hline Constant & $\begin{array}{l}0.664 \\
(0.631)\end{array}$ & $\begin{array}{l}1.035 * \\
(0.438)\end{array}$ & $\begin{array}{l}0.929 * \\
(0.369)\end{array}$ & $\begin{array}{l}0.895 * \\
(0.375)\end{array}$ & $\begin{array}{l}0.971 * \\
(0.405)\end{array}$ & $\begin{array}{l}0.892 * \\
(0.367)\end{array}$ \\
\hline Variance terms & & & & & & \\
\hline State intercepts & 0.000 & 0.000 & 0.000 & 0.000 & 0.000 & 0.000 \\
\hline Ind. intercepts & 0.118 & 0.127 & 0.125 & 0.123 & 0.126 & 0.124 \\
\hline Residuals & 0.089 & 0.073 & 0.078 & 0.078 & 0.078 & 0.079 \\
\hline $\mathrm{N}$ & 14,528 & 23,618 & 37,036 & 35,544 & 30,027 & 38,146 \\
\hline
\end{tabular}

Each column is a separate linear multilevel regression model. See Appendix Table 11 for sample and model specifications. Coefficients from Models (1) and (2) are from the first-difference models, so, different from the table label, the coefficients shown are those without the interactions with treatment status

${ }^{+} \mathrm{p}<0.10 . * \mathrm{p}<0.05 . * * \mathrm{p}<0.01 . * * * \mathrm{p}<.001$ 
Table 15 First-difference results and sensitivity analyses-trajectories of work hours and policy stringencies

\begin{tabular}{|c|c|c|c|c|c|c|}
\hline & \multicolumn{6}{|c|}{ Average monthly work hours } \\
\hline & \multicolumn{2}{|c|}{ First-difference } & \multicolumn{4}{|l|}{ DDD } \\
\hline & $\begin{array}{l}\text { Treatment: } \\
\text { Single } \\
\text { mothers } \\
(1)\end{array}$ & $\begin{array}{l}\text { Comparison: } \\
\text { Married } \\
\text { mothers } \\
(2)\end{array}$ & $\begin{array}{l}\text { Women arrived } \\
\text { in the state } \\
\text { before } 1992 \\
\text { (3) }\end{array}$ & $\begin{array}{l}\text { Women } \\
\text { responded in all } \\
\text { survey years } \\
\text { (4) }\end{array}$ & $\begin{array}{l}\text { States that did not } \\
\text { change TL/ SC } \\
\text { policies } \\
\text { (5) }\end{array}$ & $\begin{array}{l}\text { Control for } \\
\text { SNAP policy } \\
\text { characteristics } \\
(6)\end{array}$ \\
\hline \multicolumn{7}{|c|}{ Years since policy influence (YPI) (reference: -2 to -1 year) } \\
\hline $0-1$ year $\times$ treat & $\begin{array}{l}-7.028 * \\
(2.862)\end{array}$ & $\begin{array}{l}-0.946 \\
(1.791)\end{array}$ & $\begin{array}{l}-3.242 \\
(3.338)\end{array}$ & $\begin{array}{l}-5.136 \\
(3.500)\end{array}$ & $\begin{array}{l}-1.764 \\
(4.039)\end{array}$ & $\begin{array}{l}-1.762 \\
(3.360)\end{array}$ \\
\hline $2-3$ year $\times$ treat & $\begin{array}{l}-6.383^{+} \\
(3.511)\end{array}$ & $\begin{array}{l}2.847 \\
(2.562)\end{array}$ & $\begin{array}{l}-4.138 \\
(4.139)\end{array}$ & $\begin{array}{l}-6.248 \\
(4.278)\end{array}$ & $\begin{array}{l}-4.014 \\
(5.030)\end{array}$ & $\begin{array}{l}-4.404 \\
(4.079)\end{array}$ \\
\hline $4-5$ year $\times$ treat & $\begin{array}{l}- \\
11.978 * * * \\
(3.623)\end{array}$ & $\begin{array}{l}-4.033 \\
(2.737)\end{array}$ & $\begin{array}{l}-7.190^{+} \\
(4.360)\end{array}$ & $\begin{array}{l}-9.290 * \\
(4.539)\end{array}$ & $\begin{array}{l}-5.808 \\
(5.231)\end{array}$ & $\begin{array}{l}-6.693 \\
(4.493)\end{array}$ \\
\hline $6-7$ year $\times$ treat & $\begin{array}{l}-5.445 \\
(3.780)\end{array}$ & $\begin{array}{l}-2.462 \\
(2.857)\end{array}$ & $\begin{array}{l}-4.358 \\
(4.243)\end{array}$ & $\begin{array}{l}-6.369 \\
(4.431)\end{array}$ & $\begin{array}{l}-2.704 \\
(5.038)\end{array}$ & $\begin{array}{l}-4.395 \\
(4.979)\end{array}$ \\
\hline $8-10$ year $\times$ treat & $\begin{array}{l}-12.176^{* *} \\
(4.050)\end{array}$ & $\begin{array}{l}-3.929 \\
(3.055)\end{array}$ & $\begin{array}{l}-6.916 \\
(4.491)\end{array}$ & $\begin{array}{l}-10.033 * \\
(4.665)\end{array}$ & $\begin{array}{l}-8.068 \\
(5.440)\end{array}$ & $\begin{array}{l}-6.495 \\
(5.431)\end{array}$ \\
\hline \multicolumn{7}{|l|}{ YPI $\times$ sanction } \\
\hline $0-1$ year $\times$ treat $\times$ full sanction & $\begin{array}{l}3.887 \\
(4.818)\end{array}$ & $\begin{array}{l}0.897 \\
(3.233)\end{array}$ & $\begin{array}{l}1.568 \\
(5.905)\end{array}$ & $\begin{array}{l}2.424 \\
(6.418)\end{array}$ & $\begin{array}{l}1.181 \\
(6.252)\end{array}$ & $\begin{array}{l}3.713 \\
(5.854)\end{array}$ \\
\hline $2-3$ year $\times$ treat $\times$ full sanction & $\begin{array}{l}0.868 \\
(5.416)\end{array}$ & $\begin{array}{l}-1.902 \\
(4.073)\end{array}$ & $\begin{array}{l}-0.144 \\
(6.712)\end{array}$ & $\begin{array}{l}0.736 \\
(7.031)\end{array}$ & $\begin{array}{l}1.161 \\
(7.217)\end{array}$ & $\begin{array}{l}4.681 \\
(6.858)\end{array}$ \\
\hline $4-5$ year $\times$ treat $\times$ full sanction & $\begin{array}{l}-0.137 \\
(6.404)\end{array}$ & $\begin{array}{l}3.189 \\
(4.955)\end{array}$ & $\begin{array}{l}-4.746 \\
(8.109)\end{array}$ & $\begin{array}{l}-5.234 \\
(8.610)\end{array}$ & $\begin{array}{l}-5.227 \\
(8.468)\end{array}$ & $\begin{array}{l}-0.957 \\
(8.045)\end{array}$ \\
\hline $6-7$ year $\times$ treat $\times$ full sanction & $\begin{array}{l}-0.991 \\
(5.835)\end{array}$ & $\begin{array}{l}-0.549 \\
(4.448)\end{array}$ & $\begin{array}{l}-4.279 \\
(7.308)\end{array}$ & $\begin{array}{l}-4.445 \\
(7.855)\end{array}$ & $\begin{array}{l}-3.437 \\
(7.681)\end{array}$ & $\begin{array}{l}0.462 \\
(7.267)\end{array}$ \\
\hline $8-10$ year $\times$ treat $\times$ full sanction & $\begin{array}{l}5.607 \\
(6.022)\end{array}$ & $\begin{array}{l}0.941 \\
(4.709)\end{array}$ & $\begin{array}{l}-0.016 \\
(7.639)\end{array}$ & $\begin{array}{l}1.696 \\
(8.152)\end{array}$ & $\begin{array}{l}4.917 \\
(8.088)\end{array}$ & $\begin{array}{l}4.670 \\
(7.536)\end{array}$ \\
\hline \multicolumn{7}{|l|}{ YPI $\times$ time limit } \\
\hline $0-1$ year $\times$ treat $\times<60$ month & $\begin{array}{l}11.766^{*} \\
(5.727)\end{array}$ & $\begin{array}{l}0.823 \\
(3.999)\end{array}$ & $\begin{array}{l}13.637^{+} \\
(7.083)\end{array}$ & $\begin{array}{l}14.263^{+} \\
(7.560)\end{array}$ & $\begin{array}{l}12.138^{\wedge} \\
(7.855)\end{array}$ & $\begin{array}{l}10.092 \\
(7.016)\end{array}$ \\
\hline $2-3$ year $\times<60$ month & $\begin{array}{l}16.030^{* \wedge} \\
(6.986)\end{array}$ & $\begin{array}{l}4.319 \\
(5.311)\end{array}$ & $\begin{array}{l}17.776^{*} \\
(8.666)\end{array}$ & $\begin{array}{l}16.194^{+} \\
(9.158)\end{array}$ & $\begin{array}{l}16.719^{+} \\
(9.968)\end{array}$ & $\begin{array}{l}12.099 \\
(8.678)\end{array}$ \\
\hline $4-5$ year $\times$ treat $\times<60$ month & $\begin{array}{l}7.908 \\
(7.204)\end{array}$ & $\begin{array}{l}-11.085^{+} \\
(6.546)\end{array}$ & $\begin{array}{l}22.945^{* \wedge \wedge} \\
(9.640)\end{array}$ & $\begin{array}{l}25.546^{* \wedge \wedge} \\
(10.157)\end{array}$ & $\begin{array}{l}26.962 * * \\
(10.436)\end{array}$ & $\begin{array}{l}20.380 * \\
(9.642)\end{array}$ \\
\hline $6-7$ year $\times$ treat $\times<60$ month & $\begin{array}{l}16.338^{* \wedge} \\
(6.840)\end{array}$ & $\begin{array}{l}-4.166 \\
(5.880)\end{array}$ & $\begin{array}{l}27.461 * * \wedge \wedge \\
(8.735)\end{array}$ & $\begin{array}{l}27.669^{* * \wedge \wedge} \\
(9.413)\end{array}$ & $\begin{array}{l}28.853^{* * \wedge \wedge} \\
(9.717)\end{array}$ & $\begin{array}{l}26.373^{* * \wedge \wedge} \\
(8.884)\end{array}$ \\
\hline $8-10$ year $\times$ treat $\times<60$ month & $\begin{array}{l}10.967 \\
(7.587)\end{array}$ & $\begin{array}{l}1.768 \\
(6.354)\end{array}$ & $\begin{array}{l}17.593^{+} \\
(9.758)\end{array}$ & $\begin{array}{l}20.158 * \\
(10.160)\end{array}$ & $\begin{array}{l}19.402^{+\wedge \wedge} \\
(10.643)\end{array}$ & $\begin{array}{l}18.376^{+} \\
(9.901)\end{array}$ \\
\hline Treat & - & - & $\begin{array}{l}-45.011^{*} \\
(22.723)\end{array}$ & $\begin{array}{l}-45.369^{+} \\
(23.406)\end{array}$ & $\begin{array}{l}-29.020 \\
(26.478)\end{array}$ & $\begin{array}{l}-26.562 \\
(24.159)\end{array}$ \\
\hline Treat $\times$ full sanction & - & - & $\begin{array}{l}-0.039 \\
(6.382)\end{array}$ & $\begin{array}{l}-1.359 \\
(6.998)\end{array}$ & $\begin{array}{l}0.013 \\
(6.819)\end{array}$ & $\begin{array}{l}-3.953 \\
(6.193)\end{array}$ \\
\hline Treat $\times<60$ month & - & - & $\begin{array}{l}-19.570^{* *} \\
(7.420)\end{array}$ & $\begin{array}{l}-20.331^{*} \\
(8.113)\end{array}$ & $\begin{array}{l}-21.590^{* *} \\
(8.378)\end{array}$ & $\begin{array}{l}-17.638^{*} \\
(7.355)\end{array}$ \\
\hline Constant & $\begin{array}{l}245.157 * \\
(104.614)\end{array}$ & $\begin{array}{l}-14.631 \\
(83.010)\end{array}$ & $\begin{array}{l}91.681 \\
(66.649)\end{array}$ & $\begin{array}{l}86.221 \\
(67.316)\end{array}$ & $\begin{array}{l}118.404 \\
(73.610)\end{array}$ & $\begin{array}{l}97.445 \\
(66.181)\end{array}$ \\
\hline
\end{tabular}


Table 15 (continued)

\begin{tabular}{|c|c|c|c|c|c|c|}
\hline & \multicolumn{6}{|c|}{ Average monthly work hours } \\
\hline & \multicolumn{2}{|c|}{ First-difference } & \multicolumn{4}{|l|}{ DDD } \\
\hline & $\begin{array}{l}\text { Treatment: } \\
\text { Single } \\
\text { mothers } \\
(1)\end{array}$ & $\begin{array}{l}\text { Comparison: } \\
\text { Married } \\
\text { mothers } \\
(2)\end{array}$ & $\begin{array}{l}\text { Women arrived } \\
\text { in the state } \\
\text { before } 1992 \\
\text { (3) }\end{array}$ & $\begin{array}{l}\text { Women } \\
\text { responded in all } \\
\text { survey years } \\
\text { (4) }\end{array}$ & $\begin{array}{l}\text { States that did not } \\
\text { change TL/ SC } \\
\text { policies } \\
\text { (5) }\end{array}$ & $\begin{array}{l}\text { Control for } \\
\text { SNAP policy } \\
\text { characteristics } \\
\text { (6) }\end{array}$ \\
\hline $\mathrm{N}$ & 14,528 & 23,618 & 37,036 & 35,544 & 30,027 & 38,146 \\
\hline
\end{tabular}

Each column is a separate linear Heckman selection regression model. See Appendix Table 11 for sample and model specifications. Standard errors are in parentheses. Coefficients from Model (1) and (2) are from the first-difference models, so, different from the table label, the coefficients shown are those without the interactions with treatment status

${ }^{+} \mathrm{p}<0.10 . * \mathrm{p}<0.05$. **p $<0.01 . * * * \mathrm{p}<.001$

Table 16 First-difference results and sensitivity analyses-trajectories of earned income and policy stringencies

\begin{tabular}{|c|c|c|c|c|c|c|}
\hline & \multicolumn{6}{|c|}{ Log (monthly earnings) } \\
\hline & \multicolumn{2}{|c|}{ First-difference } & \multicolumn{4}{|l|}{ DDD } \\
\hline & $\begin{array}{l}\text { Treatment: } \\
\text { Single } \\
\text { mothers } \\
(1)\end{array}$ & $\begin{array}{l}\text { Comparison: } \\
\text { Married } \\
\text { mothers } \\
(2)\end{array}$ & $\begin{array}{l}\text { Women arrived } \\
\text { in the state } \\
\text { before } 1992 \\
\text { (3) }\end{array}$ & $\begin{array}{l}\text { Women } \\
\text { responded in all } \\
\text { survey years } \\
\text { (4) }\end{array}$ & $\begin{array}{l}\text { States that did not } \\
\text { change TL/ SC } \\
\text { policies } \\
\text { (5) }\end{array}$ & $\begin{array}{l}\text { Control for } \\
\text { SNAP policy } \\
\text { characteristics } \\
(6)\end{array}$ \\
\hline \multicolumn{7}{|c|}{ Years since policy influence (YPI) (reference: -2 to -1 year) } \\
\hline $0-1$ year $\times$ treat & $\begin{array}{l}-0.087^{+} \\
(0.047)\end{array}$ & $\begin{array}{l}0.025 \\
(0.029)\end{array}$ & $\begin{array}{l}0.001 \\
(0.049)\end{array}$ & $\begin{array}{l}-0.009 \\
(0.052)\end{array}$ & $\begin{array}{l}0.043 \\
(0.060)\end{array}$ & $\begin{array}{l}0.026 \\
(0.050)\end{array}$ \\
\hline $2-3$ year $\times$ treat & $\begin{array}{l}-0.066 \\
(0.059)\end{array}$ & $\begin{array}{l}0.084 * \\
(0.041)\end{array}$ & $\begin{array}{l}-0.005 \\
(0.061)\end{array}$ & $\begin{array}{l}-0.003 \\
(0.063)\end{array}$ & $\begin{array}{l}-0.015 \\
(0.073)\end{array}$ & $\begin{array}{l}0.004 \\
(0.061)\end{array}$ \\
\hline $4-5$ year $\times$ treat & $\begin{array}{l}-0.116^{+} \\
(0.063)\end{array}$ & $\begin{array}{l}0.021 \\
(0.045)\end{array}$ & $\begin{array}{l}-0.007 \\
(0.068)\end{array}$ & $\begin{array}{l}-0.017 \\
(0.071)\end{array}$ & $\begin{array}{l}-0.010 \\
(0.081)\end{array}$ & $\begin{array}{l}-0.011 \\
(0.071)\end{array}$ \\
\hline $6-7$ year $\times$ treat & $\begin{array}{l}-0.033 \\
(0.067)\end{array}$ & $\begin{array}{l}0.049 \\
(0.047)\end{array}$ & $\begin{array}{l}-0.022 \\
(0.066)\end{array}$ & $\begin{array}{l}-0.026 \\
(0.069)\end{array}$ & $\begin{array}{l}0.009 \\
(0.079)\end{array}$ & $\begin{array}{l}-0.036 \\
(0.080)\end{array}$ \\
\hline $8-10$ year $\times$ treat & $\begin{array}{l}-0.134^{+} \\
(0.072)\end{array}$ & $\begin{array}{l}0.024 \\
(0.049)\end{array}$ & $\begin{array}{l}-0.076 \\
(0.071)\end{array}$ & $\begin{array}{l}-0.084 \\
(0.074)\end{array}$ & $\begin{array}{l}-0.096 \\
(0.085)\end{array}$ & $\begin{array}{l}-0.091 \\
(0.088)\end{array}$ \\
\hline \multicolumn{7}{|l|}{ YPI $\times$ sanction } \\
\hline $0-1$ year $\times$ treat $\times$ full sanction & $\begin{array}{l}0.014 \\
(0.085)\end{array}$ & $\begin{array}{l}0.017 \\
(0.053)\end{array}$ & $\begin{array}{l}0.079 \\
(0.087)\end{array}$ & $\begin{array}{l}0.113 \\
(0.096)\end{array}$ & $\begin{array}{l}0.020 \\
(0.091)\end{array}$ & $\begin{array}{l}0.086 \\
(0.087)\end{array}$ \\
\hline $2-3$ year $\times$ treat $\times$ full sanction & $\begin{array}{l}0.024 \\
(0.095)\end{array}$ & $\begin{array}{l}-0.011 \\
(0.069)\end{array}$ & $\begin{array}{l}0.048 \\
(0.101)\end{array}$ & $\begin{array}{l}0.056 \\
(0.108)\end{array}$ & $\begin{array}{l}0.034 \\
(0.108)\end{array}$ & $\begin{array}{l}0.078 \\
(0.105)\end{array}$ \\
\hline $4-5$ year $\times$ treat $\times$ full sanction & $\begin{array}{l}0.106 \\
(0.110)\end{array}$ & $\begin{array}{l}0.144^{+} \\
(0.079)\end{array}$ & $\begin{array}{l}-0.078 \\
(0.123)\end{array}$ & $\begin{array}{l}-0.063 \\
(0.131)\end{array}$ & $\begin{array}{l}-0.065 \\
(0.128)\end{array}$ & $\begin{array}{l}-0.020 \\
(0.125)\end{array}$ \\
\hline $6-7$ year $\times$ treat $\times$ full sanction & $\begin{array}{l}0.054 \\
(0.104)\end{array}$ & $\begin{array}{l}0.079 \\
(0.075)\end{array}$ & $\begin{array}{l}-0.045 \\
(0.114)\end{array}$ & $\begin{array}{l}-0.014 \\
(0.123)\end{array}$ & $\begin{array}{l}-0.062 \\
(0.119)\end{array}$ & $\begin{array}{l}0.016 \\
(0.116)\end{array}$ \\
\hline $8-10$ year $\times$ treat $\times$ full sanction & $\begin{array}{l}0.067 \\
(0.110)\end{array}$ & $\begin{array}{l}0.076 \\
(0.078)\end{array}$ & $\begin{array}{l}-0.002 \\
(0.120)\end{array}$ & $\begin{array}{l}0.026 \\
(0.129)\end{array}$ & $\begin{array}{l}0.007 \\
(0.127)\end{array}$ & $\begin{array}{l}0.059 \\
(0.121)\end{array}$ \\
\hline \multicolumn{7}{|l|}{ YPI $\times$ time limit } \\
\hline $0-1$ year $\times$ treat $\times<60$ month & $\begin{array}{l}-0.028 \\
(0.095)\end{array}$ & $\begin{array}{l}-0.027 \\
(0.060)\end{array}$ & $\begin{array}{l}-0.019 \\
(0.099)\end{array}$ & $\begin{array}{l}-0.009 \\
(0.103)\end{array}$ & $\begin{array}{l}0.042 \\
(0.107)\end{array}$ & $\begin{array}{l}-0.065 \\
(0.099)\end{array}$ \\
\hline $2-3$ year $\times<60$ month & $\begin{array}{l}0.084 \\
(0.112)\end{array}$ & $\begin{array}{l}-0.007 \\
(0.074)\end{array}$ & $\begin{array}{l}0.135 \\
(0.111)\end{array}$ & $\begin{array}{l}0.097 \\
(0.114)\end{array}$ & $\begin{array}{l}0.201 \\
(0.123)\end{array}$ & $\begin{array}{l}0.074 \\
(0.112)\end{array}$ \\
\hline
\end{tabular}


Table 16 (continued)

\begin{tabular}{|c|c|c|c|c|c|c|}
\hline & \multicolumn{6}{|c|}{ Log (monthly earnings) } \\
\hline & \multicolumn{2}{|c|}{ First-difference } & \multicolumn{4}{|l|}{ DDD } \\
\hline & $\begin{array}{l}\text { Treatment: } \\
\text { Single } \\
\text { mothers } \\
\text { (1) }\end{array}$ & $\begin{array}{l}\text { Comparison: } \\
\text { Married } \\
\text { mothers } \\
(2)\end{array}$ & $\begin{array}{l}\text { Women arrived } \\
\text { in the state } \\
\text { before } 1992 \\
\text { (3) }\end{array}$ & $\begin{array}{l}\text { Women } \\
\text { responded in all } \\
\text { survey years } \\
\text { (4) }\end{array}$ & $\begin{array}{l}\text { States that did not } \\
\text { change TL/ SC } \\
\text { policies } \\
\text { (5) }\end{array}$ & $\begin{array}{l}\text { Control for } \\
\text { SNAP policy } \\
\text { characteristics } \\
(6)\end{array}$ \\
\hline \multirow[t]{2}{*}{$4-5$ year $\times$ treat $x<60$ month } & 0.051 & $-0.199^{* \wedge \wedge}$ & $0.245^{+}$ & $0.267^{+}$ & $0.374 *$ & 0.170 \\
\hline & $(0.131)$ & $(0.096)$ & $(0.147)$ & $(0.154)$ & $(0.156)$ & $(0.152)$ \\
\hline \multirow[t]{2}{*}{$6-7$ year $\times$ treat $x<60$ month } & 0.190 & -0.066 & $0.283^{* \wedge}$ & $0.250^{+}$ & $0.388^{* *}$ & $0.240^{+}$ \\
\hline & $(0.122)$ & $(0.090)$ & $(0.132)$ & $(0.139)$ & $(0.142)$ & $(0.137)$ \\
\hline \multirow[t]{2}{*}{$8-10$ year $\times$ treat $\times<60$ month } & 0.132 & 0.017 & 0.166 & 0.125 & 0.249 & 0.129 \\
\hline & $(0.136)$ & $(0.099)$ & $(0.151)$ & $(0.155)$ & $(0.162)$ & $(0.155)$ \\
\hline \multirow[t]{2}{*}{ Treat } & - & - & -0.166 & -0.148 & 0.008 & 0.058 \\
\hline & & & $(0.365)$ & $(0.377)$ & $(0.421)$ & $(0.384)$ \\
\hline \multirow[t]{2}{*}{ Treat $\times$ full sanction } & - & - & -0.022 & -0.045 & -0.004 & -0.057 \\
\hline & & & $(0.096)$ & $(0.106)$ & $(0.101)$ & $(0.097)$ \\
\hline \multirow[t]{2}{*}{ Treat $\times<60$ month } & - & - & -0.152 & -0.147 & $-0.298 *$ & -0.143 \\
\hline & & & $(0.108)$ & $(0.115)$ & $(0.116)$ & $(0.108)$ \\
\hline \multirow[t]{2}{*}{ Constant } & $7.956 * * *$ & $3.399^{*}$ & $4.183 * * *$ & $4.782 * * *$ & $3.240 * *$ & $4.641 * * *$ \\
\hline & $(1.848)$ & (1.384) & (1.069) & (1.091) & $(1.215)$ & (1.064) \\
\hline $\mathrm{N}$ & 14,423 & 23,233 & 36,556 & 35,079 & 29,618 & 37,656 \\
\hline
\end{tabular}

Each column is a separate linear Heckman selection regression model. I add all income values by 1 before taking a logarithm of the outcome. See Appendix Table 11 for sample and model specifications. Income values are expressed in January 1996 US dollars using the Consumer Price Index. Standard errors are in parentheses. Coefficients from Models (1) and (2) are from the first-difference models, so, different from the table label, the coefficients shown are those without the interactions with treatment status

${ }^{+} \mathrm{p}<0.10 . * \mathrm{p}<0.05 . * * \mathrm{p}<0.01 . * * * \mathrm{p}<.001$

Table 17 First-difference results and sensitivity analyses—-trajectories of family income and policy stringencies

\begin{tabular}{|c|c|c|c|c|c|c|}
\hline & \multicolumn{6}{|c|}{ Log (monthly family income) } \\
\hline & \multicolumn{2}{|c|}{ First-difference } & \multicolumn{4}{|l|}{ DDD } \\
\hline & $\begin{array}{l}\text { Treatment: } \\
\text { single } \\
\text { mothers } \\
(1)\end{array}$ & $\begin{array}{l}\text { Comparison: } \\
\text { married } \\
\text { mothers } \\
(2)\end{array}$ & $\begin{array}{l}\text { Women arrived } \\
\text { in the state } \\
\text { before } 1992 \\
\text { (3) }\end{array}$ & $\begin{array}{l}\text { Women } \\
\text { responded in all } \\
\text { survey years } \\
\text { (4) }\end{array}$ & $\begin{array}{l}\text { States that did not } \\
\text { change TL/ SC } \\
\text { policies } \\
\text { (5) }\end{array}$ & $\begin{array}{l}\text { Control for } \\
\text { SNAP policy } \\
\text { characteristics } \\
(6)\end{array}$ \\
\hline \multicolumn{7}{|c|}{ Years since policy influence (YPI) (reference: -2 to -1 year) } \\
\hline $0-1$ year $\times$ treat & $\begin{array}{l}0.107 * * * \\
(0.030)\end{array}$ & $\begin{array}{l}0.086 * * * \\
(0.017)\end{array}$ & $\begin{array}{l}-0.006 \\
(0.031)\end{array}$ & $\begin{array}{l}0.018 \\
(0.033)\end{array}$ & $\begin{array}{l}-0.001 \\
(0.038)\end{array}$ & $\begin{array}{l}-0.001 \\
(0.032)\end{array}$ \\
\hline $2-3$ year $\times$ treat & $\begin{array}{l}0.096^{*} \\
(0.038)\end{array}$ & $\begin{array}{l}0.109 * * * \\
(0.021)\end{array}$ & $\begin{array}{l}-0.047 \\
(0.039)\end{array}$ & $\begin{array}{l}-0.036 \\
(0.040)\end{array}$ & $\begin{array}{l}-0.030 \\
(0.047)\end{array}$ & $\begin{array}{l}-0.043 \\
(0.039)\end{array}$ \\
\hline $4-5$ year $\times$ treat & $\begin{array}{l}0.203 * * * \\
(0.043)\end{array}$ & $\begin{array}{l}0.148 * * * \\
(0.025)\end{array}$ & $\begin{array}{l}0.063 \\
(0.045)\end{array}$ & $\begin{array}{l}0.069 \\
(0.047)\end{array}$ & $\begin{array}{l}0.028 \\
(0.054)\end{array}$ & $\begin{array}{l}0.065 \\
(0.047)\end{array}$ \\
\hline $6-7$ year $\times$ treat & $\begin{array}{l}0.220 * * * \\
(0.046)\end{array}$ & $\begin{array}{l}0.202 * * * \\
(0.027)\end{array}$ & $\begin{array}{l}0.034 \\
(0.047)\end{array}$ & $\begin{array}{l}0.044 \\
(0.048)\end{array}$ & $\begin{array}{l}0.011 \\
(0.055)\end{array}$ & $\begin{array}{l}0.031 \\
(0.054)\end{array}$ \\
\hline $8-10$ year $\times$ treat & $\begin{array}{l}0.175 * * * \\
(0.050)\end{array}$ & $\begin{array}{l}0.227 * * * \\
(0.030)\end{array}$ & $\begin{array}{l}-0.031 \\
(0.050)\end{array}$ & $\begin{array}{l}-0.019 \\
(0.051)\end{array}$ & $\begin{array}{l}-0.073 \\
(0.059)\end{array}$ & $\begin{array}{l}-0.029 \\
(0.059)\end{array}$ \\
\hline
\end{tabular}


Table 17 (continued)

\begin{tabular}{|c|c|c|c|c|c|c|}
\hline & \multicolumn{6}{|c|}{ Log (monthly family income) } \\
\hline & \multicolumn{2}{|c|}{ First-difference } & \multicolumn{4}{|l|}{ DDD } \\
\hline & $\begin{array}{l}\text { Treatment: } \\
\text { single } \\
\text { mothers } \\
(1)\end{array}$ & $\begin{array}{l}\text { Comparison: } \\
\text { married } \\
\text { mothers } \\
(2)\end{array}$ & $\begin{array}{l}\text { Women arrived } \\
\text { in the state } \\
\text { before } 1992 \\
\text { (3) }\end{array}$ & $\begin{array}{l}\text { Women } \\
\text { responded in all } \\
\text { survey years } \\
(4)\end{array}$ & $\begin{array}{l}\text { States that did not } \\
\text { change TL/ SC } \\
\text { policies } \\
\text { (5) }\end{array}$ & $\begin{array}{l}\text { Control for } \\
\text { SNAP policy } \\
\text { characteristics } \\
(6)\end{array}$ \\
\hline \multirow[t]{2}{*}{$0-1$ year $\times$ treat $\times$ full sanction } & -0.013 & -0.001 & 0.003 & -0.046 & 0.025 & -0.016 \\
\hline & $(0.051)$ & $(0.030)$ & $(0.056)$ & $(0.060)$ & $(0.059)$ & $(0.056)$ \\
\hline \multirow[t]{2}{*}{$2-3$ year $\times$ treat $\times$ full sanction } & 0.011 & 0.003 & 0.016 & -0.013 & 0.052 & -0.008 \\
\hline & $(0.058)$ & $(0.034)$ & $(0.062)$ & $(0.063)$ & $(0.065)$ & $(0.064)$ \\
\hline \multirow[t]{2}{*}{$4-5$ year $\times$ treat $\times$ full sanction } & $0.148^{+}$ & 0.063 & 0.085 & 0.059 & 0.143 & 0.079 \\
\hline & $(0.077)$ & $(0.048)$ & $(0.085)$ & $(0.089)$ & $(0.089)$ & $(0.087)$ \\
\hline \multirow[t]{2}{*}{ 6-7 year $\times$ treat $X$ Full Sanction } & 0.058 & 0.013 & 0.032 & 0.024 & 0.061 & 0.030 \\
\hline & $(0.072)$ & $(0.045)$ & $(0.081)$ & $(0.085)$ & $(0.085)$ & $(0.082)$ \\
\hline \multirow[t]{2}{*}{$8-10$ year $\times$ treat $X$ Full Sanction } & 0.124 & 0.015 & 0.105 & 0.070 & 0.132 & 0.095 \\
\hline & $(0.078)$ & $(0.048)$ & $(0.087)$ & $(0.090)$ & $(0.091)$ & $(0.087)$ \\
\hline \multicolumn{7}{|l|}{ YPI $\times$ time limit } \\
\hline \multirow[t]{2}{*}{$0-1$ year $\times$ treat $x<60$ month } & $-0.119^{+}$ & -0.002 & -0.112 & $-0.160^{+}$ & -0.108 & -0.119 \\
\hline & $(0.070)$ & $(0.040)$ & $(0.077)$ & $(0.083)$ & $(0.083)$ & $(0.075)$ \\
\hline \multirow[t]{2}{*}{$2-3$ year $x<60$ month } & 0.032 & -0.029 & 0.023 & 0.015 & 0.074 & 0.036 \\
\hline & $(0.078)$ & $(0.045)$ & $(0.085)$ & $(0.087)$ & $(0.091)$ & $(0.083)$ \\
\hline \multirow[t]{2}{*}{ 4-5 year $\times$ treat $x<60$ month } & 0.058 & -0.007 & 0.040 & 0.033 & 0.105 & 0.029 \\
\hline & $(0.101)$ & $(0.061)$ & $(0.113)$ & $(0.117)$ & $(0.120)$ & $(0.111)$ \\
\hline \multirow[t]{2}{*}{ 6-7 year $\times$ treat $x<60$ month } & -0.114 & 0.028 & $-0.186^{+}$ & $-0.205^{+}$ & -0.136 & -0.177 \\
\hline & $(0.098)$ & $(0.060)$ & $(0.109)$ & $(0.114)$ & $(0.117)$ & $(0.109)$ \\
\hline \multirow[t]{2}{*}{$8-10$ year $\times$ treat $\times<60$ month } & -0.015 & 0.014 & -0.096 & -0.098 & -0.016 & -0.100 \\
\hline & $(0.108)$ & $(0.066)$ & $(0.120)$ & $(0.125)$ & $(0.128)$ & $(0.121)$ \\
\hline \multirow[t]{2}{*}{ Treat } & - & - & -0.389 & $-0.519^{+}$ & -0.284 & -0.354 \\
\hline & & & $(0.304)$ & $(0.313)$ & $(0.363)$ & $(0.319)$ \\
\hline \multirow[t]{2}{*}{ Treat $\times$ full sanction } & - & - & -0.088 & -0.075 & -0.096 & -0.083 \\
\hline & & & $(0.067)$ & $(0.072)$ & $(0.072)$ & $(0.068)$ \\
\hline \multirow[t]{2}{*}{ Treat $x<60$ month } & - & - & 0.038 & 0.044 & -0.006 & 0.047 \\
\hline & & & $(0.088)$ & $(0.096)$ & $(0.095)$ & $(0.087)$ \\
\hline \multirow[t]{2}{*}{ Constant } & $6.085 * * *$ & $9.047 * * *$ & $8.110 * * *$ & $8.361 * * *$ & $8.265 * * *$ & $8.169 * * *$ \\
\hline & $(1.461)$ & $(0.818)$ & $(0.764)$ & $(0.773)$ & $(0.834)$ & $(0.759)$ \\
\hline \multicolumn{7}{|l|}{ Variance terms } \\
\hline State intercepts & 0.000 & 0.000 & 0.000 & 0.000 & 0.000 & 0.000 \\
\hline Ind. intercepts & 0.052 & 0.355 & 0.431 & 0.423 & 0.430 & 0.429 \\
\hline Residuals & 0.519 & 0.276 & 0.370 & 0.365 & 0.364 & 0.369 \\
\hline $\mathrm{N}$ & 14,528 & 23,618 & 37,036 & 35,544 & 30,027 & 38,146 \\
\hline
\end{tabular}

Each column is a separate linear multilevel regression model. I add all income values by 1 before taking a logarithm of the outcome. See Appendix Table 11 for sample and model specifications. Income values are expressed in January 1996 US dollars using the Consumer Price Index. Standard errors are in parentheses. Coefficients from Models (1) and (2) are from the first-difference models, so, different from the table label, the coefficients shown are those without the interactions with treatment status

${ }^{+} \mathrm{p}<0.10 . * \mathrm{p}<0.05$. $* * \mathrm{p}<0.01 . * * * \mathrm{p}<.001$ 
Table 18 First-difference results and sensitivity analyses-trajectories of financial independence and policy stringencies

\begin{tabular}{|c|c|c|c|c|c|c|}
\hline & \multicolumn{6}{|c|}{$\begin{array}{l}\text { Financial independence } \\
\text { (No public or private assistance) }\end{array}$} \\
\hline & \multicolumn{2}{|c|}{ First-difference } & \multicolumn{4}{|l|}{ DDD } \\
\hline & $\begin{array}{l}\text { Treatment: } \\
\text { single } \\
\text { mothers } \\
(1)\end{array}$ & $\begin{array}{l}\text { Comparison: } \\
\text { married } \\
\text { mothers } \\
(2)\end{array}$ & $\begin{array}{l}\text { Women arrived } \\
\text { in the state } \\
\text { before } 1992 \\
\text { (3) }\end{array}$ & $\begin{array}{l}\text { Women } \\
\text { responded in all } \\
\text { survey years } \\
\text { (4) }\end{array}$ & $\begin{array}{l}\text { States that did not } \\
\text { change TL/ SC } \\
\text { policies } \\
\text { (5) }\end{array}$ & $\begin{array}{l}\text { Control for } \\
\text { SNAP policy } \\
\text { characteristics } \\
\text { (6) }\end{array}$ \\
\hline \multicolumn{7}{|c|}{ Years since policy influence (YPI) (reference: -2 to -1 year) } \\
\hline $0-1$ year $\times$ treat & $\begin{array}{l}0.062 * * * \\
(0.011)\end{array}$ & $\begin{array}{l}0.013 * \\
(0.006)\end{array}$ & $\begin{array}{l}0.041 * * * \\
(0.012)\end{array}$ & $\begin{array}{l}0.036 * * \\
(0.012)\end{array}$ & $\begin{array}{l}0.036^{*} \\
(0.014)\end{array}$ & $\begin{array}{l}0.042 * * * \\
(0.012)\end{array}$ \\
\hline $2-3$ year $\times$ treat & $\begin{array}{l}0.138 * * * \\
(0.014)\end{array}$ & $\begin{array}{l}0.030 * * * \\
(0.008)\end{array}$ & $\begin{array}{l}0.106 * * * \\
(0.015)\end{array}$ & $\begin{array}{l}0.103 * * * \\
(0.015)\end{array}$ & $\begin{array}{l}0.109 * * * \\
(0.018)\end{array}$ & $\begin{array}{l}0.109 * * * \\
(0.015)\end{array}$ \\
\hline $4-5$ year $\times$ treat & $\begin{array}{l}0.104 * * * \\
(0.017)\end{array}$ & $\begin{array}{l}-0.000 \\
(0.010)\end{array}$ & $\begin{array}{l}0.109 * * * \\
(0.018)\end{array}$ & $\begin{array}{l}0.112 * * * \\
(0.018)\end{array}$ & $\begin{array}{l}0.113 * * * \\
(0.021)\end{array}$ & $\begin{array}{l}0.109 * * * \\
(0.018)\end{array}$ \\
\hline $6-7$ year $\times$ treat & $\begin{array}{l}0.098 * * * \\
(0.019)\end{array}$ & $\begin{array}{l}-0.004 \\
(0.011)\end{array}$ & $\begin{array}{l}0.112 * * * \\
(0.019)\end{array}$ & $\begin{array}{l}0.115^{* * * *} \\
(0.019)\end{array}$ & $\begin{array}{l}0.119 * * * \\
(0.022)\end{array}$ & $\begin{array}{l}0.117 * * * \\
(0.021)\end{array}$ \\
\hline $8-10$ year $\times$ treat & $\begin{array}{l}0.059 * * \\
(0.020)\end{array}$ & $\begin{array}{l}-0.026^{*} \\
(0.012)\end{array}$ & $\begin{array}{l}0.093 * * * \\
(0.020)\end{array}$ & $\begin{array}{l}0.096 * * * \\
(0.021)\end{array}$ & $\begin{array}{l}0.095 * * * \\
(0.023)\end{array}$ & $\begin{array}{l}0.104 * * * \\
(0.023)\end{array}$ \\
\hline \multicolumn{7}{|l|}{ YPI $\times$ sanction } \\
\hline $0-1$ year $\times$ treat $\times$ full sanction & $\begin{array}{l}0.003 \\
(0.019)\end{array}$ & $\begin{array}{l}-0.000 \\
(0.011)\end{array}$ & $\begin{array}{l}0.004 \\
(0.021)\end{array}$ & $\begin{array}{l}0.013 \\
(0.022)\end{array}$ & $\begin{array}{l}0.011 \\
(0.022)\end{array}$ & $\begin{array}{l}0.004 \\
(0.021)\end{array}$ \\
\hline $2-3$ year $\times$ treat $\times$ full sanction & $\begin{array}{l}-0.003 \\
(0.021)\end{array}$ & $\begin{array}{l}-0.015 \\
(0.013)\end{array}$ & $\begin{array}{l}0.007 \\
(0.023)\end{array}$ & $\begin{array}{l}0.007 \\
(0.024)\end{array}$ & $\begin{array}{l}-0.009 \\
(0.024)\end{array}$ & $\begin{array}{l}-0.000 \\
(0.024)\end{array}$ \\
\hline $4-5$ year $\times$ treat $\times$ full sanction & $\begin{array}{l}-0.032 \\
(0.031)\end{array}$ & $\begin{array}{l}-0.004 \\
(0.019)\end{array}$ & $\begin{array}{l}-0.027 \\
(0.035)\end{array}$ & $\begin{array}{l}-0.054 \\
(0.036)\end{array}$ & $\begin{array}{l}-0.034 \\
(0.036)\end{array}$ & $\begin{array}{l}-0.034 \\
(0.035)\end{array}$ \\
\hline $6-7$ year $\times$ treat $\times$ full sanction & $\begin{array}{l}-0.031 \\
(0.030)\end{array}$ & $\begin{array}{l}-0.015 \\
(0.018)\end{array}$ & $\begin{array}{l}-0.017 \\
(0.033)\end{array}$ & $\begin{array}{l}-0.035 \\
(0.035)\end{array}$ & $\begin{array}{l}-0.027 \\
(0.035)\end{array}$ & $\begin{array}{l}-0.024 \\
(0.034)\end{array}$ \\
\hline $8-10$ year $\times$ treat $\times$ full sanction & $\begin{array}{l}-0.023 \\
(0.033)\end{array}$ & $\begin{array}{l}0.009 \\
(0.020)\end{array}$ & $\begin{array}{l}-0.029 \\
(0.036)\end{array}$ & $\begin{array}{l}-0.043 \\
(0.037)\end{array}$ & $\begin{array}{l}-0.033 \\
(0.037)\end{array}$ & $\begin{array}{l}-0.035 \\
(0.036)\end{array}$ \\
\hline \multicolumn{7}{|l|}{ YPI $\times$ time limit } \\
\hline $0-1$ year $\times$ treat $\times<60$ month & $\begin{array}{l}-0.007 \\
(0.026)\end{array}$ & $\begin{array}{l}-0.027^{+} \\
(0.015)\end{array}$ & $\begin{array}{l}0.024 \\
(0.029)\end{array}$ & $\begin{array}{l}0.010 \\
(0.031)\end{array}$ & $\begin{array}{l}0.024 \\
(0.031)\end{array}$ & $\begin{array}{l}0.017 \\
(0.028)\end{array}$ \\
\hline $2-3$ year $\times<60$ month & $\begin{array}{l}0.072 * \wedge \wedge \\
(0.029)\end{array}$ & $\begin{array}{l}-0.010 \\
(0.017)\end{array}$ & $\begin{array}{l}0.081 * \wedge \\
(0.032)\end{array}$ & $\begin{array}{l}0.074 * \\
(0.033)\end{array}$ & $\begin{array}{l}0.096 * * \wedge \wedge \\
(0.034)\end{array}$ & $\begin{array}{l}0.079 * \wedge \\
(0.031)\end{array}$ \\
\hline $4-5$ year $\times$ treat $x<60$ month & $\begin{array}{l}0.059^{\wedge} \\
(0.041)\end{array}$ & $\begin{array}{l}-0.039 \\
(0.024)\end{array}$ & $\begin{array}{l}0.077^{+\wedge} \\
(0.045)\end{array}$ & $\begin{array}{l}0.073^{\wedge \wedge} \\
(0.047)\end{array}$ & $\begin{array}{l}0.111^{* \wedge \wedge} \\
(0.048)\end{array}$ & $\begin{array}{l}0.090^{* \wedge \wedge} \\
(0.045)\end{array}$ \\
\hline $6-7$ year $\times$ treat $\times<60$ month & $\begin{array}{l}0.102 * \wedge \wedge \\
(0.041)\end{array}$ & $\begin{array}{l}-0.022 \\
(0.024)\end{array}$ & $\begin{array}{l}0.120 * * \wedge \wedge \\
(0.045)\end{array}$ & $\begin{array}{l}0.099 * \wedge \wedge \\
(0.047)\end{array}$ & $\begin{array}{l}0.139 * * \wedge \wedge \\
(0.048)\end{array}$ & $\begin{array}{l}0.113^{* \wedge \wedge} \\
(0.045)\end{array}$ \\
\hline $8-10$ year $\times$ treat $\times<60$ month & $\begin{array}{l}0.115^{* \wedge \wedge} \\
(0.045)\end{array}$ & $\begin{array}{l}-0.027 \\
(0.027)\end{array}$ & $\begin{array}{l}0.129 * * \wedge \wedge \\
(0.049)\end{array}$ & $\begin{array}{l}0.127 * \wedge \wedge \\
(0.051)\end{array}$ & $\begin{array}{l}0.150^{* * \wedge \wedge} \\
(0.052)\end{array}$ & $\begin{array}{l}0.139 * * \wedge \wedge \\
(0.050)\end{array}$ \\
\hline Treat & - & - & $\begin{array}{l}-0.173 \\
(0.133)\end{array}$ & $\begin{array}{l}-0.158 \\
(0.138)\end{array}$ & $\begin{array}{l}-0.267 \mathrm{v} \\
(0.160)\end{array}$ & $\begin{array}{l}-0.227 \\
(0.138)\end{array}$ \\
\hline
\end{tabular}


Table 18 (continued)

Financial independence

(No public or private assistance)

\begin{tabular}{|c|c|c|c|c|c|}
\hline \multicolumn{2}{|c|}{ First-difference } & \multicolumn{4}{|l|}{ DDD } \\
\hline $\begin{array}{l}\text { Treatment: } \\
\text { single } \\
\text { mothers } \\
\text { (1) }\end{array}$ & $\begin{array}{l}\text { Comparison: } \\
\text { married } \\
\text { mothers } \\
\text { (2) }\end{array}$ & $\begin{array}{l}\text { Women arrived } \\
\text { in the state } \\
\text { before } 1992 \\
\text { (3) }\end{array}$ & $\begin{array}{l}\text { Women } \\
\text { responded in all } \\
\text { survey years } \\
\text { (4) }\end{array}$ & $\begin{array}{l}\text { States that did not } \\
\text { change TL/ SC } \\
\text { policies } \\
\text { (5) }\end{array}$ & $\begin{array}{l}\text { Control for } \\
\text { SNAP policy } \\
\text { characteristics } \\
(6)\end{array}$ \\
\hline- & - & $\begin{array}{l}-0.012 \\
(0.028)\end{array}$ & $\begin{array}{l}-0.001 \\
(0.030)\end{array}$ & $\begin{array}{l}0.007 \\
(0.030)\end{array}$ & $\begin{array}{l}-0.001 \\
(0.029)\end{array}$ \\
\hline- & - & $\begin{array}{l}-0.070^{+} \\
(0.037)\end{array}$ & $\begin{array}{l}-0.075^{+} \\
(0.040)\end{array}$ & $\begin{array}{l}-0.099 * \\
(0.040)\end{array}$ & $\begin{array}{l}-0.076^{*} \\
(0.036)\end{array}$ \\
\hline $\begin{array}{l}-0.035 \\
(0.586)\end{array}$ & $\begin{array}{l}0.223 \\
(0.325)\end{array}$ & $\begin{array}{l}0.199 \\
(0.304)\end{array}$ & $\begin{array}{l}0.162 \\
(0.309)\end{array}$ & $\begin{array}{l}0.173 \\
(0.330)\end{array}$ & $\begin{array}{l}0.138 \\
(0.303)\end{array}$ \\
\hline 0.000 & 0.000 & 0.000 & 0.000 & 0.000 & 0.000 \\
\hline 0.133 & 0.068 & 0.095 & 0.094 & 0.096 & 0.095 \\
\hline 0.069 & 0.040 & 0.051 & 0.051 & 0.049 & 0.051 \\
\hline 14,528 & 23,618 & 37,036 & 35,544 & 30,027 & 38,146 \\
\hline
\end{tabular}

Each column is a separate linear multilevel regression model. See Appendix Table 11 for sample and model specifications. Standard errors are in parentheses. Coefficients from Models (1) and (2) are from the first-difference models, so, different from the table label, the coefficients shown are those without the interactions with treatment status

${ }^{+} \mathrm{p}<0.10 . * \mathrm{p}<0.05 . * * \mathrm{p}<0.01 . * * * \mathrm{p}<.001$ 


\section{Appendix 3}

Figures of predicted values of Model (1) in Tables 3, 4, 5, 6 and 7.

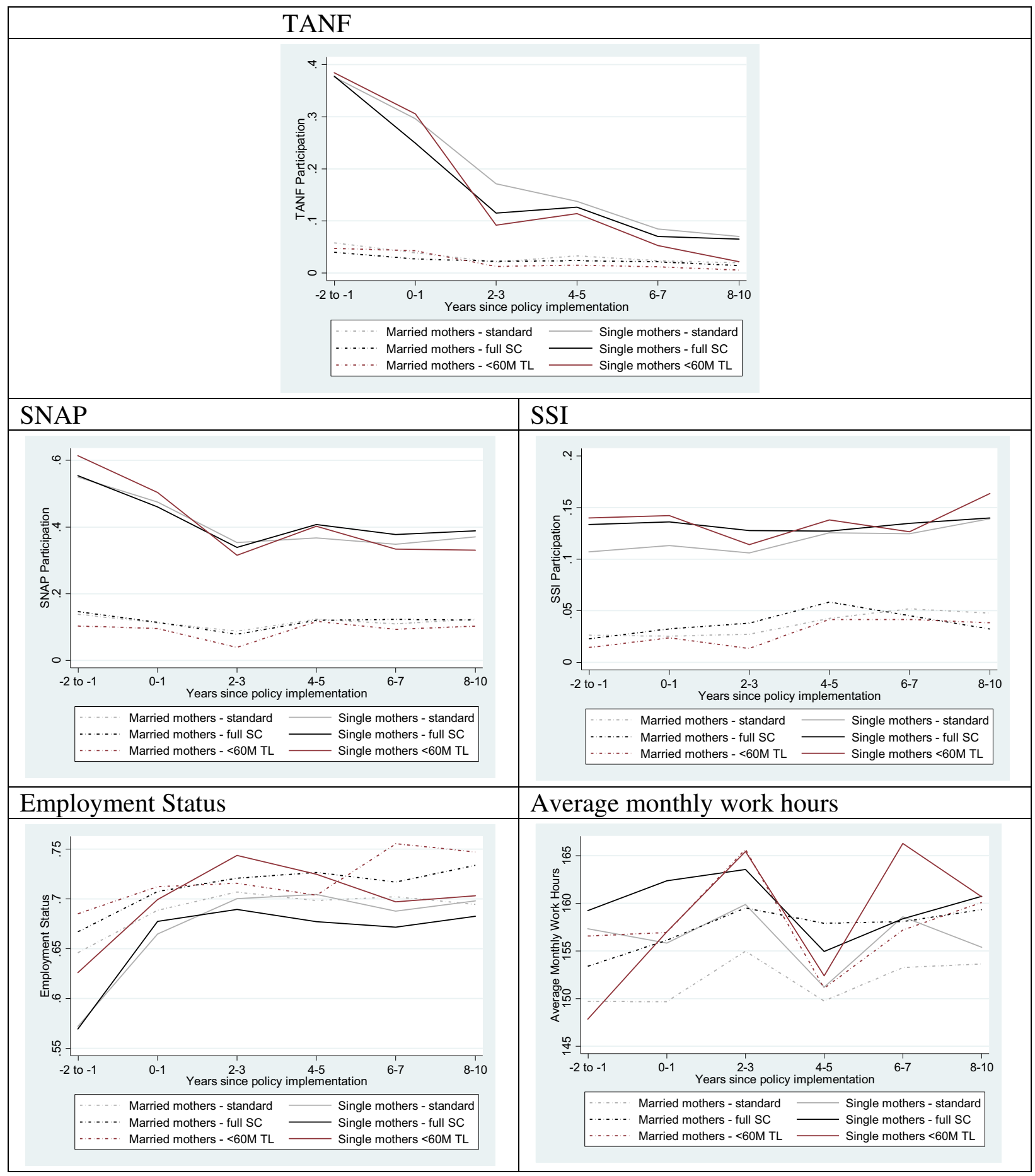




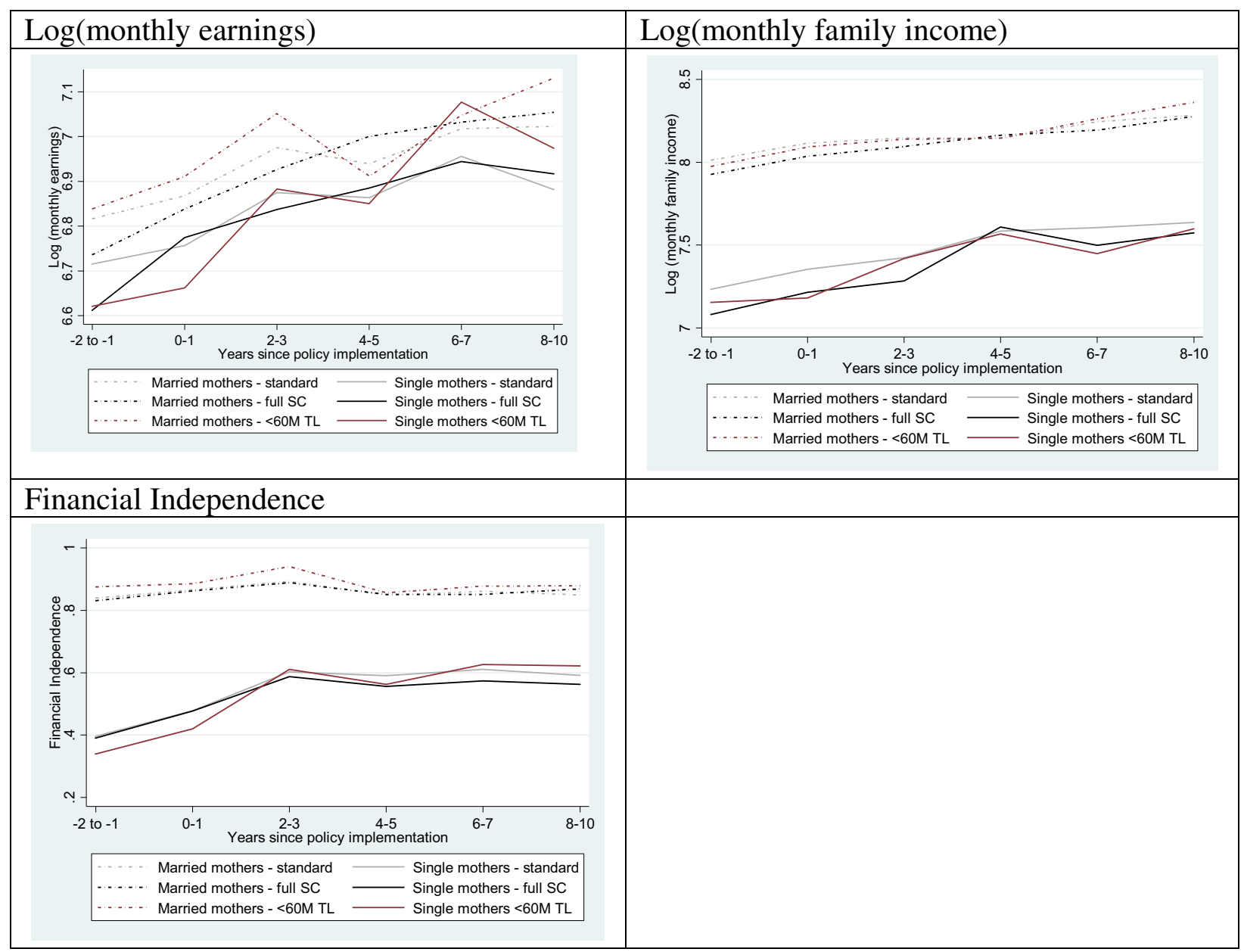

Note: TL represents time limits, and SC represents sanctions. 


\section{Appendix 4}

See Tables 19 and 20.

Table 19 States with less than 60 months of TANF time limits

\begin{tabular}{|c|c|c|c|c|c|c|c|c|c|c|c|}
\hline State & 1997 & 1998 & 1999 & 2000 & 2001 & 2002 & 2003 & 2004 & 2005 & 2006 & 2007 \\
\hline Alabama & - & - & - & - & - & - & - & - & - & - & - \\
\hline Alaska & - & - & - & - & - & - & - & - & - & - & - \\
\hline Arizona & - & - & - & - & - & - & - & - & - & - & - \\
\hline Arkansas & $24 \mathrm{M}$ & $24 \mathrm{M}$ & $24 \mathrm{M}$ & $24 \mathrm{M}$ & $24 \mathrm{M}$ & $24 \mathrm{M}$ & $24 \mathrm{M}$ & $24 \mathrm{M}$ & $24 \mathrm{M}$ & $24 \mathrm{M}$ & $24 \mathrm{M}$ \\
\hline California & - & - & - & - & - & - & - & - & - & - & - \\
\hline Colorado & - & - & - & - & - & - & - & - & - & - & - \\
\hline Connecticut & $21 \mathrm{M}$ & $21 \mathrm{M}$ & $21 \mathrm{M}$ & $21 \mathrm{M}$ & $21 \mathrm{M}$ & $21 \mathrm{M}$ & $21 \mathrm{M}$ & $21 \mathrm{M}$ & $21 \mathrm{M}$ & $21 \mathrm{M}$ & $21 \mathrm{M}$ \\
\hline Delaware & - & - & - & $36 \mathrm{M}$ & $36 \mathrm{M}$ & $36 \mathrm{M}$ & $36 \mathrm{M}$ & $36 \mathrm{M}$ & $36 \mathrm{M}$ & $36 \mathrm{M}$ & $36 \mathrm{M}$ \\
\hline District of Columbia & - & - & - & - & - & - & - & - & - & - & - \\
\hline Florida & $48 \mathrm{M}$ & $48 \mathrm{M}$ & $48 \mathrm{M}$ & $48 \mathrm{M}$ & $48 \mathrm{M}$ & $48 \mathrm{M}$ & $48 \mathrm{M}$ & $48 \mathrm{M}$ & $48 \mathrm{M}$ & $48 \mathrm{M}$ & $48 \mathrm{M}$ \\
\hline Georgia & $48 \mathrm{M}$ & $48 \mathrm{M}$ & $48 \mathrm{M}$ & $48 \mathrm{M}$ & $48 \mathrm{M}$ & $48 \mathrm{M}$ & $48 \mathrm{M}$ & $48 \mathrm{M}$ & $48 \mathrm{M}$ & $48 \mathrm{M}$ & $48 \mathrm{M}$ \\
\hline Hawaii & - & - & - & - & - & - & - & - & - & - & - \\
\hline Idaho & $24 \mathrm{M}$ & $24 \mathrm{M}$ & $24 \mathrm{M}$ & $24 \mathrm{M}$ & $24 \mathrm{M}$ & $24 \mathrm{M}$ & $24 \mathrm{M}$ & $24 \mathrm{M}$ & $24 \mathrm{M}$ & $24 \mathrm{M}$ & $24 \mathrm{M}$ \\
\hline Illinois & - & - & - & - & - & - & - & - & - & - & - \\
\hline Indiana & - & - & - & - & - & - & - & - & - & - & - \\
\hline Iowa & - & - & - & - & - & - & - & - & - & - & - \\
\hline Kansas & - & - & - & - & - & - & - & - & - & - & - \\
\hline Kentucky & - & - & - & - & - & - & - & - & - & - & - \\
\hline Louisiana & - & - & - & - & - & - & - & - & - & - & - \\
\hline Maine & - & - & - & - & - & - & - & - & - & - & - \\
\hline Maryland & - & - & - & - & - & - & - & - & - & - & - \\
\hline Massachusetts & - & - & - & - & - & - & - & - & - & - & - \\
\hline Michigan & - & - & - & - & - & - & - & - & - & - & - \\
\hline Minnesota & - & - & - & - & - & - & - & - & - & - & - \\
\hline Mississippi & - & - & - & - & - & - & - & - & - & - & - \\
\hline Missouri & - & - & - & - & - & - & - & - & - & - & - \\
\hline Montana & $24 \mathrm{M}$ & $24 \mathrm{M}$ & $24 \mathrm{M}$ & $24 \mathrm{M}$ & - & - & - & - & - & - & - \\
\hline Nebraska & - & - & - & - & - & - & - & - & - & - & - \\
\hline Nevada & - & - & - & - & - & - & - & - & - & - & - \\
\hline New Hampshire & - & - & - & - & - & - & - & - & - & - & - \\
\hline New Jersey & - & - & - & - & - & - & - & - & - & - & - \\
\hline New Mexico & - & - & - & - & - & - & - & - & - & - & - \\
\hline New York & - & - & - & - & - & - & - & - & - & - & - \\
\hline North Carolina & - & - & - & - & - & - & - & - & - & - & - \\
\hline North Dakota & - & - & - & - & - & - & - & - & - & - & - \\
\hline Ohio & - & - & - & - & - & - & - & - & - & - & - \\
\hline Oklahoma & - & - & - & - & - & - & - & - & - & - & - \\
\hline Oregon & - & - & - & - & - & - & - & - & - & - & - \\
\hline Pennsylvania & - & - & - & - & - & - & - & - & - & - & - \\
\hline Rhode Island & - & - & - & - & - & - & - & - & - & - & - \\
\hline South Carolina & - & - & - & - & - & - & - & - & - & - & - \\
\hline South Dakota & - & - & - & - & - & - & - & - & - & - & - \\
\hline Tennessee & - & - & - & - & - & - & - & - & - & - & - \\
\hline Texas & - & - & - & - & - & - & - & - & - & - & - \\
\hline
\end{tabular}


Table 19 (continued)

\begin{tabular}{llllllllllll}
\hline State & 1997 & 1998 & 1999 & 2000 & 2001 & 2002 & 2003 & 2004 & 2005 & 2006 & 2007 \\
\hline Utah & $36 \mathrm{M}$ & $36 \mathrm{M}$ & $36 \mathrm{M}$ & $36 \mathrm{M}$ & $36 \mathrm{M}$ & $36 \mathrm{M}$ & $36 \mathrm{M}$ & $36 \mathrm{M}$ & $36 \mathrm{M}$ & $36 \mathrm{M}$ & $36 \mathrm{M}$ \\
Vermont & - & - & - & - & - & - & - & - & - & - & - \\
Virginia & - & - & - & - & - & - & - & - & - & - & - \\
Washington & - & - & - & - & - & - & - & - & - & - & - \\
West Virginia & - & - & - & - & - & - & - & - & - & - & - \\
Wisconsin & - & - & - & - & - & - & - & - & - & - & - \\
Wyoming & - & - & - & - & - & - & - & - & - & - & - \\
\hline
\end{tabular}

Data source: Urban Institute Welfare Rules Database. The policy data are based on information from the third quarter of the year

Table 20 States with TANF sanctions on the full family at the initial incidence of noncompliance with work requirements

\begin{tabular}{|c|c|c|c|c|c|c|c|c|c|c|c|}
\hline State & 1997 & 1998 & 1999 & 2000 & 2001 & 2002 & 2003 & 2004 & 2005 & 2006 & 2007 \\
\hline Alabama & - & - & - & - & - & - & - & - & - & - & - \\
\hline Alaska & - & - & - & - & - & - & - & - & - & - & - \\
\hline Arizona & - & - & - & - & - & - & - & - & - & - & - \\
\hline Arkansas & Full SC & Full SC & - & - & - & - & - & - & - & - & - \\
\hline California & - & - & - & - & - & - & - & - & - & - & - \\
\hline Colorado & - & - & - & - & - & - & - & - & - & - & - \\
\hline Connecticut & - & - & - & - & - & - & - & - & - & - & - \\
\hline Delaware & - & - & - & - & - & - & - & - & - & - & Full SC \\
\hline District of Columbia & - & - & - & - & - & - & - & - & - & - & - \\
\hline Florida & Full SC & Full SC & Full SC & Full SC & Full SC & Full SC & Full SC & Full SC & Full SC & Full SC & Full SC \\
\hline Georgia & - & - & - & - & - & - & - & - & - & - & - \\
\hline Hawaii & - & - & Full SC & Full SC & Full SC & Full SC & Full SC & Full SC & Full SC & Full SC & Full SC \\
\hline Idaho & Full SC & Full SC & Full SC & Full SC & Full SC & Full SC & Full SC & Full SC & Full SC & Full SC & Full SC \\
\hline Illinois & - & - & - & - & - & - & - & - & - & - & - \\
\hline Indiana & - & - & - & - & - & - & - & - & - & - & - \\
\hline Iowa & - & - & Full SC & Full SC & Full SC & Full SC & Full SC & Full SC & Full SC & Full SC & Full SC \\
\hline Kansas & Full SC & Full SC & Full SC & Full SC & Full SC & Full SC & Full SC & Full SC & Full SC & Full SC & Full SC \\
\hline Kentucky & - & - & - & - & - & - & - & - & - & - & - \\
\hline Louisiana & - & - & - & - & - & - & - & Full SC & Full SC & Full SC & Full SC \\
\hline Maine & - & - & - & - & - & - & - & - & - & - & - \\
\hline Maryland & Full SC & Full SC & Full SC & Full SC & Full SC & Full SC & Full SC & Full SC & Full SC & Full SC & Full SC \\
\hline Massachusetts & - & - & - & - & - & - & - & - & - & - & - \\
\hline Michigan & Full SC & Full SC & Full SC & Full SC & Full SC & Full SC & Full SC & Full SC & Full SC & Full SC & Full SC \\
\hline Minnesota & - & - & - & - & - & - & - & - & - & - & - \\
\hline Mississippi & Full SC & Full SC & Full SC & Full SC & Full SC & Full SC & Full SC & Full SC & Full SC & Full SC & Full SC \\
\hline Missouri & - & - & - & - & - & - & - & - & - & - & - \\
\hline Montana & - & - & - & - & - & - & - & - & - & - & - \\
\hline Nebraska & Full SC & Full SC & Full SC & Full SC & Full SC & Full SC & Full SC & Full SC & Full SC & Full SC & Full SC \\
\hline Nevada & - & - & - & - & - & - & - & Full SC & Full SC & Full SC & Full SC \\
\hline New Hampshire & - & - & - & - & - & - & - & - & - & - & - \\
\hline New Jersey & - & - & - & - & - & - & - & - & - & - & - \\
\hline New Mexico & - & - & - & - & - & - & - & - & - & - & - \\
\hline New York & - & - & - & - & - & - & - & - & - & - & - \\
\hline North Carolina & - & - & - & - & - & - & - & - & Full SC & Full SC & Full SC \\
\hline North Dakota & - & - & - & - & - & - & - & - & - & - & - \\
\hline
\end{tabular}


Table 20 (continued)

\begin{tabular}{lllllllllllll}
\hline State & 1997 & 1998 & 1999 & 2000 & 2001 & 2002 & 2003 & 2004 & 2005 & 2006 & 2007 \\
\hline Ohio & - & - & - & - & - & - & - & Full SC & Full SC & Full SC & Full SC \\
Oklahoma & Full SC & Full SC & Full SC & Full SC & Full SC & Full SC & Full SC & Full SC & Full SC & Full SC & Full SC \\
Oregon & - & - & - & - & - & - & - & - & - & - & - \\
Pennsylvania & - & - & - & - & - & - & - & - & - & - & - \\
Rhode Island & - & - & - & - & - & - & - & - & - & - \\
South Carolina & Full SC & Full SC & Full SC & Full SC & Full SC & Full SC & Full SC & Full SC & Full SC & Full SC & Full SC \\
South Dakota & - & - & - & - & - & - & - & - & - & - \\
Tennessee & Full SC & Full SC & Full SC & Full SC & Full SC & Full SC & Full SC & Full SC & Full SC & Full SC & Full SC \\
Texas & - & - & - & - & - & - & - & Full SC & Full SC & Full SC & Full SC \\
Utah & - & - & - & - & - & - & - & - & - & - \\
Vermont & - & - & - & - & - & - & - & - & - & - \\
Virginia & Full SC & Full SC & Full SC & Full SC & Full SC & Full SC & Full SC & Full SC & Full SC & Full SC & Full SC \\
Washington & - & - & - & - & - & - & - & - & - & - \\
West Virginia & - & - & - & - & - & - & - & - & - & - \\
Wisconsin & - & - & - & - & - & - & - & - & - & - \\
Wyoming & Full SC & Full SC & Full SC & Full SC & Full SC & Full SC & Full SC & Full SC & Full SC & Full SC & Full SC
\end{tabular}

Data source: Urban Institute Welfare Rules Database. The policy data are based on information from the third quarter of the year

\section{References}

Administration for Children and Families (ACF). (2009). Characteristics and financial circumstances of TANF recipients, fiscal year 2009. Retrieved May 28, 2019, from https://www.acf.hhs.gov/ programs/ofa/resource/character/fy2009/tab46.

Administrations of Children and Families (ACF). (2012). Characteristics and financial circumstances of TANF recipients, fiscal year 2012. Retrieved May 28, 2019, from https://www.acf.hhs.gov/ sites/default/files/ofa/tanf_characteristics_fy_2012.pdf.

Administration for Children and Families (ACF). (2018). State TANF data and reports. Retrieved May 28, 2019, from https://www. acf.hhs.gov/programs/ofa/programs/tanf/data-reports.

Bailey, M. A. (2005). Welfare and the multifaceted decision to move. American Political Science Review, 99(1), 125-135. https://doi. org/10.1017/S0003055405051531.

Bitler, M. P., Gelbach, J. B., \& Hoynes, H. W. (2005). Welfare reform and health. Journal of Human Resources, 40(2), 309-334. https://doi.org/10.3368/jhr.XL.2.309.

Blank, R. M. (2002). Evaluating welfare reform in the United States. Journal of Economic Literature, 40(4), 1105-1166. https://doi. org/10.1257/002205102762203576.

Blank, R. M., \& Kovak, B. K. (2009). The growing problem of disconnected single mothers. In C. J. Heinrich \& J. K. Scholz (Eds.), Making the work-based safety net work better: Forwardlooking policies to help low-income families. New York, NY: Russell Sage Foundation.

Blundell, R., Francesconi, M., \& van der Klaauw, W. (2011). Anatomy of welfare reform evaluation: Announcement and implementation effects (No. 2572). Retrieved May 28, 2019, from https://repository.essex.ac.uk/2572/.

Cancian, M., \& Meyer, D. R. (2000). Work after welfare: Women's work effort, occupation, and economic well-being. Social Work Research, 24(2), 69-86. https://doi.org/10.1093/swr/24.2.69.

Cheng, T. C. (2007). Impact of work requirements on the psychological well-being of TANF recipients. Health \& Social Work, 32(1), 41-48. https://doi.org/10.1093/hsw/32.1.41.
Cohen, P. N., \& Blanchi, S. M. (1999). Marriage, children, and women's employment: What do we know. Monthly Labor Review, 122, 22-31.

Council of Economic Advisers. (1999). Technical report: The effects of welfare policy and the economic expansion on welfare caseloads: An update. Washington, DC: Executive Office of the President.

Danielson, C., \& Klerman, J. A. (2008). Did welfare reform cause the caseload decline? Social Service Review, 82(4), 703-730. https:// doi.org/10.1086/597347.

Danziger, S. K., Danziger, S., Seefeldt, K. S., \& Shaefer, H. L. (2016). From welfare to a work-based safety net: An incomplete transition. Journal of Policy Analysis and Management, 35(1), 231-238. https://doi.org/10.1002/pam.21880.

Dave, D. M., Reichman, N. E., Corman, H., \& Das, D. (2011). Effects of welfare reform on vocational education and training. Economics of Education Review, 30(6), 1399-1415. https://doi. org/10.1016/j.econedurev.2011.07.008.

Dave, D. M., Corman, H., \& Reichman, N. E. (2012). Effects of welfare reform on education acquisition of adult women. Journal of Labor Research, 33(2), 251-282. https://doi.org/10.1007/ s12122-012-9130-4.

Duncan, G., \& Chase-Lansdale, P. L. (2001). Welfare reform and child well-being. Northwestern University/University of Chicago Joint Center for Poverty Research.

De Jong, G. F., Garaefe, D. R., \& St. Pierre, T. (2005). Welfare reform and interstate migration of poor families. Demography, 42(3), 469-496. https://doi.org/10.1007/BF03214592.

De Jong, G. F., Garaefe, D. R., Irving, S. K., \& St. Pierre, T. (2006). Measuring state TANF policy variations and change after reforms. Social Science Quarterly, 87(4), 755-781. https://doi. org/10.1111/j.1540-6237.2006.00432.x.

Department of Health and Human Services. (2016). State welfare waivers: An overview. Retrieved May 28, 2019, from https:// aspe.hhs.gov/legacy-page/state-welfare-waivers-overview152151. 
Dyke, A., Heinrich, C. J., Mueser, P. R., Troske, K. R., \& Jeon, K. S. (2006). The effects of welfare-to-work program activities on labor market outcomes. Journal of Labor Economics, 24(3), 567-607. https://doi.org/10.1086/504642.

Economic Research Service U.S. Department of Agriculture (USDA). (2017). SNAP policy database. Retrieved May 28, 2019, from https://www.ers.usda.gov/data-products/snap-policy-database. aspx.

Edin, K. J., \& Shaefer, H. L. (2015). \$2.00 a day: Living on almost nothing in America. Boston, MA: Houghton Mifflin Harcourt.

Ellwood, D. T. (2000). The impact of the earned income tax credit and social policy reforms on work, marriage, and living arrangements. National Tax Journal, 53(4), 1063-1106.

Fang, H., \& Keane, M. P. (2004). Assessing the impact of welfare reform on single mothers. Brookings Papers on Economic Activity, 2004(1), 1-116. https://doi.org/10.1353/eca.2004.0015.

Farrell, M., Rich, S., Turner, L., Seith, D., \& Bloom, D. (2008). Welfare time limits: An update on state policies, implementation, and effects on families. New York: MDRC.

Fletcher, D. R. (2020). Introduction to the special edition. Social Policy \& Administration, 54(2), 185-190.

Freeman, E. M. (1996). Welfare reforms and services for children and families: Setting a new practice, research, and policy agenda. Social Work, 41(5), 521-532. https://doi.org/10.1093/sw/41.5. 521.

Frogner, B., Moffitt, R., Ribar, D. C., \& Ziliak, J. P. (2009). How families are doing nine years after welfare reform. In Welfare reform and its long-term consequences for America's poor (pp. 140-171).

Goodman, L. (2017). The effect of the affordable care act medicaid expansion on migration. Journal of Policy Analysis and Management, 36(1), 211-238. https://doi.org/10.1002/pam.21952.

Grogger, J. (2003). The effects of time limits, the EITC, and other policy changes on welfare use, work, and income among femaleheaded families. The Review of Economics and Statistics, 85(2), 394-408. https://doi.org/10.1162/003465303765299891.

Grogger, J. (2004). Time limits and welfare use. Journal of Human Resources, 39(2), 405-424. https://doi.org/10.3368/jhr.XXXIX. 2.405 .

Grogger, J., Haider, S. J., \& Klerman, J. (1990). Why did the welfare rolls fall during the 1990s? The importance of entry. American Economic Review, 93(2), 288-292. https://doi.org/10.1257/ 000282803321947218.

Grogger, J., \& Karoly, L. (2005). Welfare reform: Effects of a decade of change. Cambridge, MA: Harvard University Press.

Haskins, R. (2016). TANF at age 20: Work still works. Journal of Policy Analysis and Management, 35(1), 224-231. https://doi. org/10.1002/pam.21878.

Heckman, J. J. (1979). Sample selection bias as a specification error. Econometrica, 47(1), 153-161. https://doi.org/10.2307/1912352.

Huang, C. C., Garfinkel, I., \& Waldfogel, J. (2000). Child support and welfare caseloads. Institute for research on poverty. Madison: University of Wisconsin.

Huber, E., Cohen, E., Briggs, A., \& Kassabian, D. (2015). Welfare rules databook: State TANF policies as of July 2014. Washington, DC: The Urban Institute. Retrieved May 28, 2019, from https://anfdata.urban.org/databooks/2014\%2520Welfare\% 2520Rules\%2520Databook\%2520(FINAL).pdf.

Hotz, V. J., Imbens, G. W., \& Klerman, J. A. (2006). Evaluating the differential effects of alternative welfare-to-work training components: A reanalysis of the California GAIN program. Journal of Labor Economics, 24(3), 521-566. https://doi.org/10.1086/ 505050.

Jacobs, J. A., \& Winslow, S. (2003). Welfare reform and enrollment in postsecondary education. The Annals of the American
Academy of Political and Social Science, 586(1), 194-217. https://doi.org/10.1177/0002716202250224.

Johnson, V. D. (2010). Impact of race and welfare reform on African American single mothers' access to higher education. Journal of Black Studies, 40(6), 1041-1051. https://doi.org/10.1177/ 0021934708323986.

Johnson, R. C., \& Corcoran, M. E. (2003). The road to economic selfsufficiency: Job quality and job transition patterns after welfare reform. Journal of Policy Analysis and Management, 22(4), 615-639. https://doi.org/10.1002/pam.10158.

Keiser, L. R., Mueser, P. R., \& Choi, S. W. (2004). Race, bureaucratic discretion, and the implementation of welfare reform. American Journal of Political Science, 48(2), 314-327. https://doi.org/10. 1111/j.0092-5853.2004.00072.x.

Kalil, A., Seefeldt, K. S., \& Wang, H. C. (2002). Sanctions and material hardship under TANF. Social Service Review, 76(4), 642-662. https://doi.org/10.1086/342998.

Kaushal, N. (2005). New immigrants' location choices: Magnets without welfare. Journal of Labor Economics, 23(1), 59-80. https://doi.org/10.1086/425433.

Kaushal, N., \& Kaestner, R. (2001). From welfare to work: Has welfare reform worked? Journal of Policy Analysis and Management, 20(4), 699-719. https://doi.org/10.1002/pam.1024.

Kim, J. (2012). Welfare reform and college enrollment among single mothers. Social Service Review, 86(1), 69-91. https://doi.org/10. 1086/664951.

Klerman, J. A., \& Haider, S. J. (2004). A stock-flow analysis of the welfare caseload. Journal of Human Resources, 39(4), 865-886. https://doi.org/10.3368/jhr.XXXIX.4.865.

Lee, B. J., Slack, K. S., \& Lewis, D. A. (2004). Are welfare sanctions working as intended? Welfare receipt, work activity, and material hardship among TANF-recipient families. Social Service Review, 78(3), 370-403. https://doi.org/10.1086/421918.

Lim, Y., Coulton, C. J., \& Lalich, N. (2009). State TANF policies and employment outcomes among welfare leavers. Social Service Review, 83(4), 525-555. https://doi.org/10.1086/650532.

Lindhorst, T., \& Mancoske, R. J. (2006). The social and economic impact of sanctions and time limits on recipients of temporary assistance to needy families. Journal of Sociology and Social Welfare, 33(1), 93.

Loprest, P. J. (2012). How has the TANF caseload changed over time? Retrieved May 28, 2019, from https://www.urban.org/ UploadedPDF/412565-How-Has-the-TANF-Caseload-ChangedOver-Time.pdf.

Mazzolari, F. (2007). Welfare use when approaching the time limit. Journal of Human Resources, 42(3), 596-618. https://doi.org/10. 3368/jhr.XLII.3.596.

McKinnish, T. (2005). Importing the poor: Welfare magnetism and cross-border welfare migration. Journal of Human Resources, 40(1), 57-76. https://doi.org/10.3368/jhr.XL.1.57.

Meyer, B. D. (2002). Labor supply at the extensive and intensive margins: The EITC, welfare, and hours worked. American Economic Review, 92(2), 373-379. https://doi.org/10.1257/ 000282802320191642.

Meyer, B. D., \& Rosenbaum, D. T. (2001). Welfare, the earned income tax credit, and the labor supply of single mothers. Quarterly Journal of Economics, 116(3), 1063-1114. https://doi. org/10.1162/00335530152466313.

Meyer, B. D., Mok, W. K., \& Sullivan, J. X. (2009). The underreporting of transfers in household surveys: Its nature and consequences (No. w15181). National Bureau of Economic Research. https://doi.org/10.3386/w15181.

Moffitt, R. A. (1999). The effect of pre-PRWORA waivers on AFDC caseloads and female earnings, income, and labor force behavior. Economic Conditions and Welfare Reform. https://doi.org/10. 17848/9780585241043.ch4. 
Moffitt, R. A., Stevens, D. W., \& Stevens, D. W. (2001). Changing caseloads: Macro influences and micro compositions. Baltimore: Jacob France Institute, University of Baltimore.

Moore, J. C. (2008). Seam bias in the 2004 SIPP panel: Much improved, but much bias still remains (US Census Bureau Statistical Research Division Survey Methodology Research Report Series, 3, 2008).

Morgen, S. (2001). The agency of welfare workers: Negotiating devolution, privatization, and the meaning of self-sufficiency. American Anthropologist, 103(3), 747-761. https://doi.org/10. 1525/aa.2001.103.3.747.

Pavetti, L., Derr, M. K., \& Hesketh, H. (2003). Review of sanction policies and research studies. Washington, DC: US Department of Health and Human Services. Retrieved May 28, 2019, from https://aspe.hhs.gov/hsp/TANF-sanctions03.

Potochnick, S. (2016). Reversing welfare reform? Immigrant restoration efforts and food stamp receipt among Mexican immigrant families. Social Science Research, 60, 88-99. https://doi.org/10. 1016/j.ssresearch.2016.03.001.

Raudenbush, S. W., \& Bryk, A. S. (2002). Hierarchical linear models: Applications and data analysis methods. Thousand Oaks, CA: Sage.

Rector, R. E., \& Youssef, S. E. (1999). The determinants of welfare caseload decline. Washington, DC: Heritage Foundation.

Reichman, N. E., Teitler, J. O., Garfinkel, I., \& Garcia, S. (2004). Variations in maternal and child well-being among financially eligible mothers by TANF participation status. Eastern Economic Journal, 30(1), 101-118.

Reichman, N. E., Teitler, J. O., \& Curtis, M. A. (2005). TANF sanctioning and hardship. Social Service Review, 79(2), 215-236. https://doi.org/10.1086/428918.

Romich, J. L. (2006). Difficult calculations: Low-income workers and marginal tax rates. Social Service Review, 80(1), 27-66. https:// doi.org/10.1086/499086.

Rowe, G. (2000). Welfare rules databook: State TANF policies as of July 1999. Washington, DC: The Urban Institute. Retrieved May 28, 2019, from https://www.urban.org/sites/default/files/alfresco/ publication-pdfs/310284-Welfare-Rules-Databook-State-TANFPolicies-as-of-July-.PDF.

Rowe, G., Murphy, M., \& Kaminski, J. (2008). Welfare rules databook: State TANF policies as of July 2007. Washington, DC: The Urban Institute. Retrieved May 28, 2019, from https:// anfdata.urban.org/databooks/Databook\%25202007\% 2520Final\%2520Draft\%2520December\%25202008.pdf.

Schoeni, R. F., \& Blank, R. M. (2000). What has welfare reform accomplished? Impacts on welfare participation, employment, income, poverty, and family structure (No. w7627). National Bureau of Economic Research. https://doi.org/10.3386/w7627.

Schram, S. F. (2005). Contextualizing racial disparities in American welfare reform: Toward a new poverty research. Perspectives on Politics, 3(2), 253-268.

Schram, S., Nitz, L., \& Krueger, G. (1998). Without cause or effect: Reconsidering welfare migration as a policy problem. American
Journal of Political Science, 42(1), 210-230. https://doi.org/10. 2307/2991753.

Schram, S. F., Soss, J., Fording, R. C., \& Houser, L. (2009). Deciding to discipline: Race, choice, and punishment at the frontlines of welfare reform. American Sociological Review, 74(3), 398-422. https://doi.org/10.1177/000312240907400304.

Seefeldt, K. S. (2008). Working after welfare: How women balance jobs and family in the wake of welfare reform. Kalamazoo, MI: W. E. Upjohn Institute for Employment Research.

Seefeldt, K. S., \& Sandstrom, H. (2015). When there is no welfare: The income packaging strategies of disconnected mothers following an economic downturn. Russell Sage Foundation Journal of Social Sciences, 1, 139-158. https://doi.org/10.7758/ RSF.2015.1.1.08.

Swann, C. A. (2005). Welfare reform when recipients are forwardlooking. Journal of Human Resources, 40(1), 31-56. https://doi. org/10.3368/jhr.XL.1.31.

Tax Credits for Workers and Their Families. (2015). Tax credits for working families. Retrieved May 28, 2019, from https://www. taxcreditsforworkingfamilies.org/earned-income-tax-credit/ states-with-eitcs/.

Turner, L. J., Danziger, S., \& Seefeldt, K. S. (2006). Failing the transition from welfare to work: Women chronically disconnected from employment and cash welfare. Social Science Quarterly, 87(2), 227-249. https://doi.org/10.1111/j.1540-6237. 2006.00378.x.

Wiseman, M. (2002). Food stamps and welfare reform. Retrieved May 28, 2019, from https://www.brookings.edu/research/foodstamps-and-welfare-reform/.

Wu, C. F., Cancian, M., \& Wallace, G. (2014). The effect of welfare sanctions on TANF exits and employment. Children and Youth Services Review, 36, 1-14. https://doi.org/10.1016/j.childyouth. 2013.10.022.

Ziliak, J. P. (Ed.). (2009). Welfare reform and its long-term consequences for America's poor. New York, NY: Cambridge University Press.

Ziliak, J. P. (2016). Temporary assistance for needy families. In R. A. Moffitt (Ed.), Economics of means-tested transfer programs in the United States (Vol. 1). Cambridge: NBER. https://doi.org/ 10.3386/w21038.

Publisher's Note Springer Nature remains neutral with regard to jurisdictional claims in published maps and institutional affiliations.

Julia Shu-Huah Wang is an Assistant Professor at the Department of Social Work and Social Administration, the University of Hong Kong. Her research focuses on social welfare policies, poverty alleviation interventions, immigration policies, and the well-being of families. She received her bachelor's degree from Department of Social Work, National Taiwan University, and Ph.D. degree from Columbia University School of Social Work. 